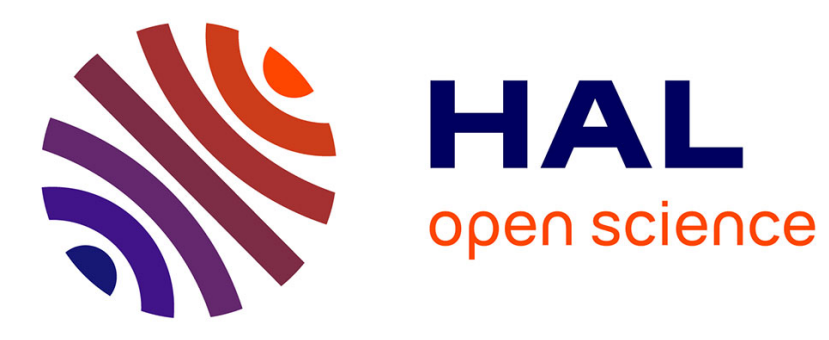

\title{
Sustainability assessment of GM crops in a Swiss agricultural context
}

Bernhard Speiser, Matthias Stolze, Bernadette Oehen, Cesare Gessler, Franco Weibel, Esther Bravin, Adeline Kilchenmann, Albert Widmer, Raffael Charles, Andreas Lang, et al.

\section{To cite this version:}

Bernhard Speiser, Matthias Stolze, Bernadette Oehen, Cesare Gessler, Franco Weibel, et al.. Sustainability assessment of GM crops in a Swiss agricultural context. Agronomy for Sustainable Development, 2012, 33 (1), pp.21-61. 10.1007/s13593-012-0088-7 . hal-01201377

\section{HAL Id: hal-01201377 \\ https://hal.science/hal-01201377}

Submitted on 17 Sep 2015

HAL is a multi-disciplinary open access archive for the deposit and dissemination of scientific research documents, whether they are published or not. The documents may come from teaching and research institutions in France or abroad, or from public or private research centers.
L'archive ouverte pluridisciplinaire HAL, est destinée au dépôt et à la diffusion de documents scientifiques de niveau recherche, publiés ou non, émanant des établissements d'enseignement et de recherche français ou étrangers, des laboratoires publics ou privés. 


\title{
Sustainability assessment of GM crops in a Swiss agricultural context
}

\author{
Bernhard Speiser • Matthias Stolze • \\ Bernadette Oehen · Cesare Gessler • Franco P. Weibel • \\ Esther Bravin • Adeline Kilchenmann • \\ Albert Widmer • Raffael Charles • Andreas Lang • \\ Christian Stamm • Peter Triloff • Lucius Tamm
}

Accepted: 28 February 2012 /Published online: 4 April 2012

(C) INRA and Springer-Verlag, France 2012

\begin{abstract}
The aim of this study was to provide an ex ante assessment of the sustainability of genetically modified (GM) crops under the agricultural conditions prevailing in Switzerland. The study addressed the gaps in our knowledge relating to (1) the agronomic risks/benefits in production systems under Swiss conditions (at field and rotation/orchard level), (2) the economic and socio-economic impacts associated with altered farming systems, and (3) the agro-ecological risks/benefits of GM crops (at field and rotation/orchard level). The study was
\end{abstract}

B. Speiser $\cdot$ M. Stolze $\cdot$ B. Oehen $\cdot$ F. P. Weibel $\cdot$ L. Tamm $(\bowtie)$

Research Institute of Organic Agriculture FiBL,

Ackerstrasse,

5070 Frick, Switzerland

e-mail: lucius.tamm@fibl.org

C. Gessler

ETH Zürich, Institut f. Integrative Biologie, LFW C15,

Universitätstrasse 2,

8092 Zürich, Switzerland

E. Bravin · A. Kilchenmann · A. Widmer $\cdot$ R. Charles

Forschungsanstalt Agroscope Changins-Wädenswil ACW,

Case postale 1012,

1260 Nyon 1, Switzerland

A. Lang

Departement Umweltwissenschaften, Universität Basel,

Bernoullistrasse 30,

4056 Basel, Switzerland

C. Stamm

Swiss Federal Institute for Environmental Sciences and

Technology (Eawag), Environmental Chemistry,

8600 Dübendorf, Switzerland

P. Triloff

Marktgemeinschaft Bodenseeobst EG,

Albert-Maier-Straße 6,

88045 Friedrichshafen, Germany based on an inventory of GM crops and traits which may be available in the next decade, and on realistic scenarios of novel agricultural practices associated with the use of GM crops in conventional, integrated, and organic farming systems in Switzerland. The technology impact assessment was conducted using an adapted version of the matrix for "comparative assessment of risks and benefits for novel agricultural systems" developed for the UK. Parameter settings were based on information from literature sources and expert workshops. In a tiered approach, sustainability criteria were defined, an inventory of potentially available, suitable GM crops was drawn up, and scenarios of baseline and novel farming systems with GM crops were developed and subsequently submitted to economic, socio-economic, and agro-ecological assessments. The project had several system boundaries, which influenced the outcomes. It was limited to the main agricultural crops used for food and feed production and focused on traits that are relevant at the field level and are likely to be commercially available within a decade from the start of the project. The study assumed that there would be no statutory restrictions on growing GM crops in all farming systems and that they would be eligible for direct payments in the same way as non-GM crops. Costs for co-existence measures were explicitly excluded and it was assumed that GM foods could be marketed in the same way as non-GM foods at equal farm gate prices. The following model GM crops were selected for this study: (1) GM maize varieties with herbicide tolerance (HT), and with resistance to the European corn borer (Ostrinia nubilalis) and the corn rootworm (Diabrotica virgifera); (2) HT wheat; (3) GM potato varieties with resistance to late blight (Phytophthora infestans), to the nematode Globodera spp., and to the Colorado beetle (Leptinotarsa decemlineata); (4) HT sugar beet with resistance to "rhizomania" (beet necrotic yellow vein virus; BNYVV); (5) apples with traditionally bred or GM resistance 
to scab (Venturia inaequalis), and GM apples with stacked resistance to scab and fire blight (Erwinia amylovora). Scenarios for arable rotations and apple orchards were developed on the basis of the model crops selected. The impact assessments were conducted for the entire model rotations/orchards in order to explore cumulative effects as well as effects that depend on the farming systems (organic, integrated, and conventional). In arable cropping systems, herbicide tolerance had the most significant impact on agronomic practices in integrated and conventional farming systems. HT crops enable altered soil and weed management strategies. While no-till soil management benefited soil conservation, the highly efficient weed control reduced biodiversity. These effects accumulated over time due to the high proportion of HT crops in the integrated and conventional model rotations. In organic production systems, the effects were less pronounced, mainly due to non-use of herbicides. Traits affecting resistance to pests and diseases had a minor impact on the overall performance of the systems, mainly due to the availability of alternative crop protection tools or traditionally bred varieties. The use of GM crops had only a minor effect on the overall profitability of the arable crop rotations. In apple production systems, scab and fire blight resistance had a positive impact on natural resources as well as on local ecology due to the reduced need for spray passages and pesticide use. In integrated apple production, disease resistance increased profitability slightly, whereas in the organic scenario, both scab and fire blight resistance increased the profitability of the systems substantially. In conclusion, the ecological and socio-economic impacts identified in this study were highly context sensitive and were associated mainly with altered production systems rather than with the GM crops per se.

Keywords Crop management - Ecological impact assessment · GM crops · Profitability · Sustainability · Swiss agriculture $\cdot$ Transgenic crops

Contents

Abstract $\ldots .1$

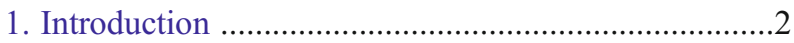

2. Methodology of the impact assessments .....................4

3. Specific assumptions for this study .............................

3.1 System boundaries of the study ................................

3.2 Model GM crops and traits selected for the

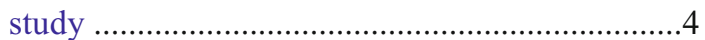

3.3 Working definitions for farming systems .............

3.4 Socio-economic context for model farms ............6

3.5 Agronomic assumptions for the model arable farms ....7

3.6 Agronomic assumptions for the model horticultural farm 10
4. Economic calculations and socio-economic assessments

4.1 Economic calculations for the model arable crops and rotations

4.2 Non-monetary impacts of GM arable crops .........21

4.3 Economic calculations for GM apples and model orchards 21

4.4 Non-monetary impacts of GM apples ...............24

5. Agro-ecological impact assessment for the cultivation of GM crops

.25

5.1 Establishment and outcrossing of GM crops in

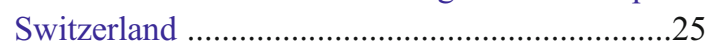

5.2 Environmental impact of HT arable crops ...........26

5.3 Environmental impact of Bt arable crops ...........30

5.4 Environmental impact of other traits in GM arable crops ......................................................... 32

5.5 Environmental impact of simplifying rotations ...32

5.6 Environmental impact of GM crops in the context of rotations .32

5.7 Environmental impact of GM apples and model orchards ..................................................... 32

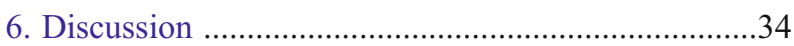

6.1 Is Swiss agriculture different from other countries? ....................................................35

6.2 Influence of model assumptions and system boundaries on the results .................................36

6.3 Compliance of GM crops with Swiss agricultural

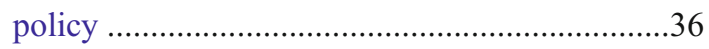

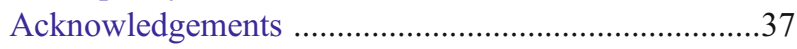

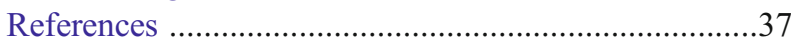

\section{Introduction}

Sustainable development is essential to maintain our natural resources and thus ensure prosperity and welfare (United Nations General Assembly 1987; UNDSD 1992). The Swiss Federal Constitution includes sustainability considerations in all aspects of its policies. According to the "Strategy for Sustainable Development" (Swiss Federal Council 2002), sustainable development has three dimensions: (1) ecological responsibility, (2) economic eficiency, and (3) social solidarity.

In the context of agriculture, a set of priorities for sustainable development has been defined by the Swiss authorities (ARE 2004; BLW 2005). Ecological responsibility is achieved if the habitat for humans, animals, and plants is conserved and natural resources are used with respect for future generations. Natural habitats and biodiversity should be conserved, renewable resources should be used only to the extent to which they can regenerate, and nonrenewable resources should be used as efficiently as possible. In addition, the negative impacts of agricultural practices on water, 
soil, air, and climate should be minimized. The aim of economic efficiency is achieved if prosperity is preserved, income and employment are maintained or increased, and competitiveness and innovation capacity is maintained. The development of social solidarity is considered sustainable if people are able to live their lives and develop their capabilities in conditions of solidarity and well-being.

Genetically modified (GM) crops have been proposed as a tool to improve the overall sustainability of agricultural production worldwide (Russell 2008; James 2010; Jones 2011; Park et al. 2011). However, practical experience has generated conflicting outcomes. In some cases, GM crops are associated with increased yields and reduced pesticide use, e.g., Gianessi (2008); James (2010). In other cases, pesticide use in GM varieties has risen (Benbrook 2004; Binimelis et al. 2009; Zhao et al. 2011). While Sanvido et al. (2006) concluded that no significant negative ecological impacts have been found, other authors have documented various negative impacts on nontarget organisms and the ecosystem (Tappeser et al. 2000; Snow et al. 2005; Soukup et al. 2011). Trigo and Cap (2006) report that crop management and the size of production units were drastically altered after the introduction of glyphosate-resistant soybean varieties, and that total arable land has greatly increased at the expense of uncultivated land. Peterson et al. (2000) concluded that the benefits and risks of any particular GM crop depend on the interactions among its ecological functions and natural history on the one hand and the agroecosystem and ecosystems within which it is embedded on the other.

The benefits and risks of GM crops are the subject of heated debate in Europe and Switzerland. To provide a scientific basis for decision-making, the Swiss National Science Foundation has initiated the National Research Program NRP 59 "Benefits and risks of the deliberate release of genetically modified plants" (www.nrp59.ch). The present study was conducted as part of this program.

GM crops have been grown commercially on a significant scale since 1996 (Gómez-Barbero and RodriguezCerezo 2006; James 2010). They are grown mainly in North America (USA, Canada), South America (Brazil, Argentina, Paraguay), Asia (China, India, Pakistan), and South Africa (James 2010). Herbicide tolerance and/or insect resistance are the dominant traits, while other traits such as virus resistance play only a marginal or local role. While the total acreage of GM crops was almost 150 million ha in the aforementioned countries, none of the European countries had more than 0.1 million ha of GM crops in 2009 (James 2010). In Switzerland, no GM crops have been grown commercially up to now. GM crops have met with considerable political opposition, and the Swiss population has voted for a temporary ban ("moratorium") on GM crops in Switzerland (Wolf and Albisser Vögeli 2009). The ban started in 2005 and was originally limited to 5 years; it has since been extended by the Swiss Federal Council until 2013.

Various quantitative, semiquantitative, and qualitative assessment methods are available to evaluate the ecological and economic impacts of farming systems. Since no GM crops are grown in Switzerland, we looked for a method that is robust and can handle missing, incomplete, imprecise, and even controversial data. Furthermore, the method had to be able to assess GM crops in a wider context, including alternative agricultural practices, ecosystem management, and agricultural policy. The semiquantitative assessment approach proposed by the "Subgroup of the Advisory Committee on Releases to the Environment" (ACRE 2007) was deemed most suitable in terms of quality, efficiency, robustness, and flexibility.

Swiss farming systems differ in many respects from those in the USA, Canada, or Argentina. The following features are characteristic of Swiss farming: (1) small farm and field size; (2) high crop diversity and complex crop rotations; (3) diverse landscape pattern, with close intermingling of agriculture, forestry, roads, and villages; (4) strict regulations on the use of pesticides and fertilizers and on farming practices; (5) a very high percentage of integrated and organic production systems with substantial direct payments. On account of these features, we expected that the effects predicted in this study might deviate substantially from practical experience with GM crops in other countries, where large-scale conventional farming systems prevail.

We hypothesized that the potential effects of GM crops are context sensitive (Russell 2008), because of the complex interactions between GM crops, management practices, the economy, and the environment. For example, the trait of herbicide resistance may be advantageous in conventional farming but is useless in a herbicide-free, organic farming system. We therefore analyzed the effects of GM crops in the context of different model rotations and model orchards, managed according to typical Swiss farming practices (organic, integrated and conventional).

The aim of this study was to provide an ex ante assessment of the sustainability of GM crops under the agricultural conditions prevailing in Switzerland. The study addressed the gaps in our knowledge relating to (1) the agronomic risks/benefits in production systems under Swiss conditions (at field and rotation/orchard level), (2) the economic and socio-economic impacts associated with altered farming systems, and (3) the agro-ecological risks/benefits of GM crops (at field and rotation/orchard level). The study was based on an inventory of GM crops and traits which may be available in the next decade and on realistic scenarios of novel agricultural practices associated with the use of GM crops in conventional, integrated and organic farming 
systems in Switzerland. The system boundaries are described in detail in "Section 3" below.

\section{Methodology of the impact assessments}

The overall objective of this study was to carry out a technology impact assessment for GM crops with production-related GM traits. The study was limited to GM crops that are potentially available within the next decade.

The methodology of a "comparative assessment of risks and benefits for novel agricultural systems" (ACRE 2007) was selected as a tool for this technology impact assessment. This method takes the following variables into account: management system and inputs required; persistence/invasiveness; impacts on biodiversity, water, soils, and energy balance; latency/cumulative effects; reversibility of effects; social and economic factors. For each of these variables, benefits and negative impacts are listed alongside an estimate of the magnitude of impact and the potential for mitigation. For the purpose of this study, the variables "persistence/invasiveness", "latency/cumulative effects", and "reversibility of effects" were pooled under the heading "establishment and outcrossing".

The study was based on information from literature sources as well as expert opinions elaborated in workshops. From 2008 to 2010, 11 workshops were conducted involving a total of 44 experts. The experts had complementary expertise in GM crops, Swiss farming practices, socio-economy under Swiss conditions, agro-ecology, and various aspects of environmental risk assessment.

In a tiered approach, the following components were developed:

- definition of sustainability criteria (expert workshop)

- inventory of potentially available, suitable GM crops (database and literature search)

- scenario development of novel farming systems with GM crops (expert workshops)

- quantitative economic assessment of novel GM farming systems (model calculations)

- semiquantitative socio-economic and agro-ecological assessment of novel GM farming systems (expert workshops)

The interim results from all these components were submitted to plausibility checks and debated by interested external experts before any final conclusions were drawn. Comments and conclusions were sometimes controversial. The present study elucidates whether a general consensus was reached or conflicting opinions remained and also where substantial gaps in knowledge were identified.

\section{Specific assumptions for this study}

\subsection{System boundaries of the study}

The project had several system boundaries, which influenced the outcomes. It was limited to agricultural crops and excluded fiber crops, energy crops, plants for recreational or urban use, crops for production of pharmaceutical or industrial substances, ornamentals, and herbs and spices. It was further limited to traits that are relevant at the farming stage of the production chain (for example, prolonged shelf life was excluded) and to crops/traits that are likely to be commercially available within a decade from the start of the project. When the project was carried out, GM apples were technically, but not commercially available (no registration). GM apples were included in this study.

The study assumed that there would be no fundamental statutory restrictions on growing GM crops (i.e., that the current "moratorium" would not be prolonged) and that the model GM crops would be registered in Switzerland. It also assumed that GM crops could be grown on organic farms, which is not currently permitted. It was assumed that GM foods could be marketed in the same way as non-GM foods (no opposition by consumers, same prices), and that they would be eligible for direct payments in the same way as non-GM crops. Costs for co-existence measures were explicitly excluded, as these have been studied in another NRP59 project (Mann 2011).

In an attempt to assess the maximum potential effects of GM crops (agronomic, socio-economic, and ecological), the model rotations assumed a full adoption of all available GM crops within the rotation. It was assumed that no unexpected side effects (see Cellini et al. 2004) would occur in the GM crops studied, that weeds would not evolve tolerance to the herbicides used, and that pests and diseases would remain susceptible to the GM trait within the time span covered by the project. Finally, the study was limited to crops that play a relatively important role in agriculture in the Swiss plateau (Mittelland).

\subsection{Model GM crops and traits selected for the study}

To determine the range of GM crops to be studied, a working list of potentially available GM crops was compiled. It was based primarily on official information (authorizations, notifications, and deliberate releases) for Switzerland and the EU. This was complemented by information from the USA and by input from private databases, company information, and input from experts. The following sources were considered: the public register of genetically modified organism (GMO) commercialization and the public register of deliberate GMO releases in Switzerland; the database of notifications for the EU and the database of deliberate 
releases within the EU published by the Joint Research Center; the database of deliberate releases and GMO marketing in the USA; the private databases "GMO Compass", "Agbios", and "Transgen". In addition, product pipelines described on the company websites of Monsanto, BayerCropScience, Syngenta, and KWS were screened. Databases were searched for entries between 1998 and 2008. We assumed that crops/traits mentioned only prior to 1998 had been unsuccessful and their development discontinued.

No GM crops are currently grown in Switzerland. The experts therefore selected a number of GM crops/traits for which registration within a decade from the beginning of the study seemed a plausible scenario. The inclusion of GM crops in the scenarios does not imply an anticipation of regulatory decisions, however.

GM traits are abbreviated as follows throughout this paper: $\mathrm{Bt}=$ insect resistant ( $\mathrm{Bt}$ genes), $\mathrm{FR}=$ fungus resistant, $\mathrm{NR}=$ nematode resistant, $\mathrm{VR}=$ virus resistant, $\mathrm{BR}=$ bacteria resistant, and HT=herbicide tolerant.

The working definition for HT crops specified that they would be tolerant to one herbicide (glyphosate, glufosinate, or another herbicide), but not to several herbicides at the same time. Although multiple herbicide tolerance is now available, it was concluded in the agronomy workshops that resistance to one herbicide per GM crop would be sufficient, provided that alternation was possible in successive years. When the management practices for each crop were detailed, specific tolerances were assigned to each model crop in such a way that glyphosate and glufosinate would be applied alternately. Such a "herbicide rotation" (Huber 2007) may prevent weed problems with herbicide-tolerant volunteer plants, or with wild plants that have become herbicide-tolerant through gene transfer. The type of herbicide tolerance is indicated as follows: $\mathrm{HT}_{\mathrm{gly}}=$ glyphosatetolerant; $\mathrm{HT}_{\mathrm{glu}}=$ glufosinate-tolerant.

For the impact assessment, the GM crops and traits are relevant, but not the exact cultivars into which these are incorporated. For this reason, the model GM crops are described in the form of "ideotypes", which possess all the GM traits judged likely to be available for that crop. It was assumed that agronomic properties, yield and quality of the GM ideotypes are the same as for corresponding non-GM varieties. The following model GM crops were selected for this study:

$H T_{g l u}$-Bt maize: GM maize varieties with tolerance to glufosinate and with resistance to the European corn borer (Ostrinia nubilalis) and the corn rootworm (Diabrotica virgifera) (Bt genes). In the conventional cash grain maize rotation no 6, a glyphosate tolerant cultivar will be grown alternately with a glufosinate tolerant cultivar. In most rotations, the maize is used for silage, which is the dominant use of maize in Switzerland. In rotation no 6, maize is used for grains. It was assumed that $20 \%$ of the land would be planted with non-Bt maize, where the corn borer is controlled using Trichogramma. This corresponds to current instructions for resistance management in France (AGPM 2007).

$H T_{g l y}$ wheat: GM wheat varieties with tolerance to glyphosate. Note: disease resistance in wheat is currently the subject of research in Switzerland (Zeller et al. 2010), but it was considered unlikely to be available for agricultural use within the time frame of 10 years.

FR-NR-Bt potato: GM potato varieties with resistance to late blight (Phytophthora infestans) based on $\mathrm{R}$ genes, to the nematode Globodera spp., and to the Colorado beetle (Leptinotarsa decemlineata).

$H T_{g l u}-V R$ sugar beet: GM cultivars of sugar beet with tolerance to glufosinate and with resistance to "rhizomania", which is caused by the beet necrotic yellow vein virus (BNYVV).

Two ideotypes of GM apples were also selected for this study, although the experts had doubts about whether GM apples will be available commercially within the study period. Nevertheless, they complement the arable crops in terms of traits and crop management, and there is great public interest in fire blight in Switzerland. The following ideotypes were selected:

FR apple: apple cultivars with resistance to scab (Venturia inaequalis). FR apple plants are available in Switzerland at the greenhouse stage but have not been field tested up to now (Gessler et al. 2006).

FR-BR apple: apple cultivars with resistance to scab and fire blight (Erwinia amylovora). Resistance to fire blight has been researched (Gianessi et al. 2002), but is less advanced than resistance to scab.

HT oilseed rape and HT soy were also considered but not included in the study. During the ecological impact assessment of GM oilseed rape (with tolerance to one herbicide), it turned out that outcrossing and dispersal of rape seed will occur and that it therefore has few chances of attaining registration. GM soy would only carry the trait of herbicide tolerance. Soy plays only a marginal role in Switzerland. It was decided in the agronomy workshops to include soy only in the organic model rotations. Under organic crop management, the trait of herbicide tolerance has no agronomic value.

\subsection{Working definitions for farming systems}

In Switzerland, farming systems and management practices are greatly influenced by direct payments as part of Swiss agricultural policy. There are three distinct farming systems: organic, integrated, and conventional.

Organic production The statutory requirements for organic production are specified in the "Organic Farming Ordinance" 
and the "ÖLN production rules" (see below). Organic farming regulations prohibit the use of GMOs at present; but for the purpose of this project, we constructed hypothetical scenarios where GM crops could be used in organic farming. The aim was to analyze the potential risks and benefits of GM crops for organic farming. The intention was not to anticipate any policy changes regarding organic farming and GMOs. The results for the organic model farms would be unchanged if the production standards of the private "Bio Suisse" label were assumed to apply in full.

Integrated production The scenarios for integrated production are based on the ÖLN production rules (ÖLN=ökologischer Leistungsnachweis or "proof of ecological performance"). ÖLN is part of the agri-environmental support scheme and is coupled with direct payments (see economic assessments). Note: the statutory ÖLN production rules are not identical to the private "IP Suisse" label.

Conventional production In this study, farming systems which do not follow the production rules for organic or integrated production are called "conventional". In these systems, there are no restrictions concerning rotations or "ecological compensation areas". As a consequence, such systems are not entitled to direct payments. The role of conventional farming has become marginal in Switzerland due to the successful adoption of "cross compliance" in the Swiss direct payments scheme. Conventional scenarios were included in this study because we hypothesized that GM crops might allow very simple rotations (including a monoculture of maize) that do not comply with the ÖLN production rules. If the benefits (reduced costs and higher revenues) of using GM crops more than compensated for the loss of direct payments, farmers would be motivated to change from integrated to conventional production. This would not only influence their economics but would also have ecological consequences. For example, integrated farms are required to maintain ecological compensation areas, yet there is no such requirement for conventional farms.

\subsection{Socio-economic context for model farms}

Because the study extends to GM crops available within the next decade, the agronomic assumptions were adapted to the socio-economic trends predicted for this period. Overviews of future trends in European and global agriculture are given in the studies "Scenar 2020" (Nowicki et al. 2007) and "FFRAF report" (Foresight Expert Group 2007). These two studies provide statistical observations regarding European agriculture and mention external drivers for these developments. In the following, a number of aspects relevant to the design of the model farms are summarized.
Production units Farm numbers in Europe are in a steady decline. There is a trend towards concentration in larger farm units, which can better take advantage of technological developments and can more easily integrate into the food chain (from production to distribution). This trend is facilitated by the liberalized European labor market and by the globalized food market. In Switzerland, where farms are comparatively small, machine work is increasingly outsourced to professional operators.

Intensity of production Production in Europe has undergone continuous intensification. This includes the large-scale use of fertilizers and pesticides, as well as rationalization, specialization, and mechanization. In the context of this study, therefore, it is anticipated that novel technologies (i.e., GM crops) will be readily adopted if they comply with this general trend.

Liberalization The liberalization process in agriculture continues. However, the outcome of future WTO negotiations is a major uncertainty in this area. Willingness to protect the environment and especially biodiversity has increased, leading to new environmental regulations (birds, habitats, nitrates, etc.). Payment schemes related to cross-compliance are therefore expected to continue.

Consumer preferences The consumption of cereals, meat (especially poultry), and dairy products has increased worldwide. In Europe, there is a shift towards fresh food, convenience food, functional food, and diet products. There is a higher demand for quality food (including labels, organic food, and fair trade products). The future trends in European consumer demands are uncertain.

Biofuels Currently, European policies favor the production of biofuels. Prices for some foods have risen due to competing demand from the biofuels industry. In the longer term, biofuels will probably be produced using nonfood biomass. Although this excludes direct competition with the food market, there may still be competition with respect to land use. Future demand for biofuels is highly uncertain, as it depends on environmental, energy, and food policies and on developments in the petroleum sector.

The trends described above pose challenges to Swiss farming that can be met by different socio-economic strategies, such as the "intensive farm", the "low-input farm", the "direct sale farm", or the "part-time farm". For this project, the model farms were assumed to follow the strategy of the "intensive farm", because with this strategy they are most likely to adopt GM crops. "Intensive farms" reduce costs through specialization, low labor input, and efficient farm structures (large field sizes). They also improve yields by using state-of-theart technology and external inputs (fertilizers, plant protection products). 
3.5 Agronomic assumptions for the model arable farms

The model arable farm was assumed to be located in the Swiss plateau (Mittelland) and to have a total size of 40 ha. Some integrated and conventional model farms include livestock, while others do not. All organic farms were assumed to be mixed farms. In the cultivation of cereals, the integrated farm was assumed not to follow the "Extenso" program for pesticide-free production of cereals and oilseed rape, which is practiced on approximately half of these crops in Switzerland. Produce was assumed to be sold to the bulk market, or used as farm fodder (silage maize, grass/clover).

\subsubsection{Model rotations}

In the "agricultural modeling" workshop, a range of model crop rotations with varying intensity were defined. Six rotations were selected, including two organic, one integrated, and three conventional rotation scenarios (Table 1). The rotation of the "DOC" ("biodynamic-organic-conventional") long-term systems comparison trial was selected as a starting point because it is well documented (Mäder et al. 2002; Mäder et al. 2006). It was adopted almost unchanged as an organic model rotation (no 1). A number of shorter, more intensive rotations were designed in order to reflect the conditions on Swiss arable farms during the study period. The rotations were developed in such a way that the GM scenario resulted in a high proportion of GM crops. For each rotation, a scenario without GM crops was compared with a scenario with GM crops.

Three intensive rotations were designed because GM traits were assumed to be more profitable in intensive rotations. However, it turned out that the ÖLN production rules allow very little flexibility in designing intensive rotations. The intensive rotations described here do not comply with the current ÖLN production rules for rotations. They are called "conventional" model rotations here. The reasons for noncompliance with ÖLN production rules are the following: rotation no 4 includes $67 \%$ of maize, while ÖLN allows only $40 \%$; rotation no 5 contains $67 \%$ of wheat and $33 \%$ of

Table 1 Description of the model rotations

\begin{tabular}{|c|c|c|c|}
\hline Model rotation & Farming system & Crops under non-GM scenario & Crops under GM scenario \\
\hline No 1 & Organic & $\begin{array}{l}\text { Maize (for silage) } \\
\text { Winter wheat } 1 \text {-green manure } \\
\text { Potatoes-green manure } \\
\text { Soy } \\
\text { Winter wheat } 2 \\
\text { Grass/clover } 1 \\
\text { Grass/clover } 2\end{array}$ & $\begin{array}{l}\text { Bt maize }{ }^{\text {a }} \text { (for silage) } \\
\text { Winter wheat } 1 \text {-green manure } \\
\text { FR-NR-Bt potatoes-green manure } \\
\text { Soy } \\
\text { Winter wheat } 2 \\
\text { Grass/clover } 1 \\
\text { Grass/clover } 2\end{array}$ \\
\hline No 2 & Organic & $\begin{array}{l}\text { Maize (for silage) } \\
\text { Winter wheat } \\
\text { Grass/clover } 1 \\
\text { Grass/clover } 2\end{array}$ & $\begin{array}{l}\text { Bt maize }^{\mathrm{a}} \text { (for silage) } \\
\text { Winter wheat } \\
\text { Grass/clover } 1 \\
\text { Grass/clover } 2\end{array}$ \\
\hline No 3 & Integrated & $\begin{array}{l}\text { Winter wheat } 1 \text {-catch crop } \\
\text { Potatoes } \\
\text { Winter wheat } 2 \text {-catch crop } \\
\text { Maize (for silage) }\end{array}$ & $\begin{array}{l}\mathrm{HT}_{\text {gly }} \text { winter wheat } 1 \text {-catch crop } \\
\text { FR-NR-Bt potatoes } \\
\mathrm{HT}_{\text {gly }} \text { winter wheat } 2 \text {-catch crop } \\
\mathrm{HT}_{\text {glu }}-\mathrm{Bt} \text { maize } \\
\text { a (for silage) }\end{array}$ \\
\hline No 4 & Conventional & $\begin{array}{l}\text { Maize } 1 \text { (for silage) } \\
\text { Maize } 2 \text { (for silage) } \\
\text { Winter wheat-catch crop }\end{array}$ & $\begin{array}{l}\mathrm{HT}_{\mathrm{glu}_{\mathrm{u}}} \mathrm{Bt} \text { maize } \\
\mathrm{HT}_{\mathrm{glu}}-\mathrm{Bt} \text { maize } \\
\mathrm{HT}_{\text {gly }} 2 \text { (for sinter wheat-catch crop }\end{array}$ \\
\hline No 5 & Conventional, stockless & $\begin{array}{l}\text { Winter wheat } 1 \\
\text { Winter wheat } 2 \\
\text { Sugar beet }\end{array}$ & $\begin{array}{l}\mathrm{HT}_{\text {gly }} \text { winter wheat } 1 \\
\mathrm{HT}_{\text {gly }} \text { winter wheat } 2 \\
\mathrm{HT}_{\text {glu }}-\mathrm{VR} \text { sugar beet }\end{array}$ \\
\hline No 6 & Conventional & Maize (for grains) & $\mathrm{HT}_{\text {glu/gly }}-\mathrm{Bt}$ maize ${ }^{\mathrm{a}}$ (for grains) \\
\hline
\end{tabular}

The sequence of crops is shown for each model rotation. Each line represents one growing season. Crops which occur more than once in a rotation are numbered

For GM crops, the traits are indicated using the following abbreviations: $H T_{g l y}$ herbicide (glyphosate) tolerant; $H T_{g l u}$ herbicide (glufosinate) tolerant; $B t$ insect resistant (Bt genes); $F R$ fungus resistant; $N R$ nematode resistant; $V R$ virus resistant. In rotation no 6, resistance to glufosinate and to glyphosate is used alternately

${ }^{a}$ For resistance management reasons the surface would be planted with $80 \%$ Bt maize $/ 20 \%$ non-Bt maize 
sugar beet, while ÖLN allows only $50 \%$ of wheat and $25 \%$ of sugar beet; rotation no 6 contains $100 \%$ of maize, while ÖLN allows only $40 \%$. Because "conventional" rotations are not eligible for direct payments by definition, it was clear a priori that they would not be profitable in the non-GM scenario. They were included in this study to investigate whether they would become profitable in the GM scenarios.

The ÖLN production rules also require a minimum number of four crops on the farm (with some exceptions for farms with grass/clover leys). To comply with this requirement, it was assumed that rotation no 3 would not be implemented on all of the model farm's land. However, the impact assessment was made only for the model rotation, assuming that this criterion was fulfilled at farm level.

For organic farming, a rotation which is almost identical to the DOC rotation (no 1) and a more simple rotation (no 2) were considered to be realistic. Each of the organic model rotations differs from the integrated and conventional rotations by having 2 years of grass/clover coverage. Because no herbicides are allowed in organic farming, no HT crops are included in the organic rotations in the GM scenario.

\subsubsection{Yields, fertilizationm and irrigation}

It was assumed that the yield potential of GM varieties is identical to the non-GM varieties (Table 2). Yields and fertilization levels for the integrated and conventional model rotations were adjusted to the "GRUDAF" norms for Switzerland (Flisch et al. 2009). In the organic model rotations, fertilization relied mostly on manure and slurry and was based on experience from the DOC trial. Only in organic potato production commercial fertilizers were used as supplements for $\mathrm{N}$ and $\mathrm{K}$. Manure and slurry were assumed to come from cattle kept in loose housing. For their nutrient content, see Table 3.

In the model rotations, manganese fertilization was included approximately 15 days after each application of glyphosate to a $\mathrm{HT}_{\text {gly }}$ crop. This was based on experience in the USA, where manganese deficiency is often observed in $\mathrm{HT}_{\mathrm{gly}}$ soy and $\mathrm{HT}_{\text {gly }}$ maize, and micronutrient fertilization of $\mathrm{HT}_{\text {gly }}$ crops is recommended as a routine (Cakmak et al. 2009; Johal and Huber 2009). Whether the presence of manganese in Swiss soils differs from soils in the USA was not assessed.

In Romania, where GM maize has been grown for a few years now, practitioners have observed that it is more sensitive to water stress than non-GM varieties (G. Paun, Agent Green, Romania, personal communication). However, there is a lack of scientific evidence and quantitative results to back this up. Due to the uncertainty regarding this phenomenon, neither irrigation nor yield losses were considered in this study. Nevertheless, in the light of climate change, such effects should not be overlooked.

\subsubsection{Weed management and tillage system}

At present, minimum tillage is widely used in Switzerland, while direct drilling ("no-till") is rare (3\% of total acreage for arable crops; Ledermann and Schneider 2008). Direct drilling is practiced by only a few farmers who are able to manage the weed problems associated with this practice. Thus, minimum tillage was assumed for the non-GM scenarios in all farming systems. In HT crops, a novel form of weed management is possible, consisting of the postemergence application of a total herbicide. This practice is typically accompanied by no-till management. For the GM scenarios on integrated and conventional farms, direct drilling was assumed for all HT crops. Since no herbicides are authorized in organic farming, no such change was assumed for the organic model rotations.

\subsubsection{Alternating use of glyphosate and glufosinate}

Continuous use of the same herbicide bears the risk that weeds become resistant to this substance. Currently, glyphosate-resistant races have been documented for 15
Table 2 Yields and fertilization levels for the model crops

For integrated (INT) and conventional (CONV) farming, values for yield and fertilization levels were based on "GRUDAF" (Flisch et al. 2009). For organic (ORG) farming, yields were based on the DOC trial (see text)

Values in brackets not included in model rotations

\begin{tabular}{|c|c|c|c|c|c|c|}
\hline \multirow[b]{2}{*}{ Crops } & \multicolumn{2}{|l|}{ Yield (dt/ha) } & \multicolumn{4}{|c|}{ Fertilization level (in kg/ha) (INT/CONV) } \\
\hline & INT/CONV & ORG & $\mathrm{N}$ & $\mathrm{P}_{2} \mathrm{O}_{5}$ & $\mathrm{~K}_{2} \mathrm{O}$ & $\mathrm{Mg}$ \\
\hline Maize (for silage) & 175 & 160 & 110 & 80 & 220 & 25 \\
\hline Maize (for grains) & 95 & $(160)$ & 110 & 80 & 220 & 25 \\
\hline Winter wheat & 60 & 50 & 140 & 60 & 100 & 15 \\
\hline Potatoes & 450 & 250 & 120 & 70 & 375 & 20 \\
\hline Sugar beet & 750 & $(525)$ & 100 & 85 & 465 & 70 \\
\hline Soy & $(30)$ & 30 & 0 & 70 & 120 & 15 \\
\hline Grass-clover (5 cuts) & 115 & 100 & 140 & 90 & 275 & 35 \\
\hline Catch crop & 25 & (21) & 30 & 25 & 90 & 10 \\
\hline Green manure & $(25)$ & 21 & 0 & 0 & 0 & 0 \\
\hline
\end{tabular}


Table 3 Nutrient content of different organic fertilizers

\begin{tabular}{llcccc}
\hline $\begin{array}{l}\text { Organic } \\
\text { fertilizer }\end{array}$ & $\begin{array}{l}\text { Terminology in } \\
\text { GRUDAF }\end{array}$ & $N_{\text {available }}$ & $\mathrm{P}_{2} \mathrm{O}_{5}$ & $\mathrm{~K}_{2} \mathrm{O}$ & $\mathrm{Mg}$ \\
\hline Manure & Laufstallmist & 1.9 & 2.2 & 10.8 & 0.7 \\
Slurry & Gülle kotarm & 3.9 & 1.2 & 11.6 & 0.5 \\
\hline
\end{tabular}

Values are given in kilogram per ton for manure and kilogram per cubic meter for slurry

"GRUDAF" (Flisch et al. 2009)

plant species throughout the world, including weeds of great economic importance (Powles 2008; Johnson et al. 2009). In Europe, only few weeds have evolved glyphosate-resistant populations so far (Powles 2008). One of the species for which glyphosate-resistant races have been reported, Conyza bonariensis, has recently been found in Switzerland (Delabays and Auer 2009).

Volunteers of glyphosate-tolerant crops (particularly oilseed rape) may act as weeds in the following crop. To reduce the risks of HT oilseed rape volunteers, farmers in Canada are advised to grow oilseed rape in rotation with other crops such as wheat and barley, and GM oilseed rape is grown only once every 4 years (Beckie et al. 2004). In addition, Canadian farmers can alternate between glyphosate-, glufosinate-, bromoxynil-, and imidazolinone-tolerant varieties of oilseed rape (the latter being a non-GM variety; Beckie et al. 2004).

In order to avoid problems with herbicide-resistant weeds or volunteers, the model rotations were assumed to alternate between glyphosate-resistant and glufosinateresistant crops and their corresponding herbicides. For simplicity, each crop was designated as either glyphosate or glufosinate tolerant. In some model rotations, it takes 2 years before the herbicides are alternated (see Table 1). Only in model rotation no 6 (maize monoculture) was it necessary to assign resistance to both herbicides to the same crop.

\subsubsection{Crop-specific management practices and yield expectations}

Management practices were specified for each non-GM crop and the corresponding GM crop for integrated/conventional and for organic farming separately (see Tables 4, 5, 6, 7, 8, and 9). The full specifications are given for the baseline scenario (without GM crops). For the GM scenario, only those practices which are different from the baseline are described.

Maize In most rotations, it was assumed that maize is grown for silage; maize for grains was assumed only in rotation no 6 . In the integrated and conventional model rotations, the GM scenarios deviated from the baseline by direct drilling, by the use of a different post-emergence herbicide, and by the absence of control measures against the European corn borer $(O . n u b i$ lalis; Table 4). Differences in yield were assumed only for grain maize $(+4 \%$ for Bt maize; Gómez-Barbero and RodruigezCerezo 2007). In the organic model rotations, the GM scenarios deviated from the baseline by the absence of control measures against the corn borer. In the sensitivity analyses, it was assumed that a bivoltine race of the corn borer would spread in Switzerland and thus necessitate altered control practices. Model calculations were made either for a second release of Trichogramma or for an insecticide application (indoxacarb in integrated/conventional model rotations, spinosad in organic rotations) instead of the release of Trichogramma.

Wheat The GM scenario deviated from the baseline by direct drilling, by the use of a different post-emergence herbicide, and by Mn fertilization (Table 5). Because the trait of herbicide tolerance has no value in the absence of herbicides, GM wheat was not included in the organic GM scenarios.

Potato The model management practices for potato (Table 6) were based on the Agria variety, which is the most frequently used potato variety in Switzerland and is moderately susceptible to late blight. Fewer applications of fungicides and insecticides were assumed for the GM scenarios. These applications were assumed for control of Alternaria solanii and for resistance management of late blight. In the integrated model rotation, fungicides were reduced from eight to three applications and insecticides from one every third year to zero. In the organic model rotation, fungicides were reduced from six to three applications and insecticides from one to zero. In the sensitivity analyses, it was assumed that a highly late blightresistant variety such as Naturella would be used in the baseline scenario. Given this assumption, the fungicide application scheme was equal to that of GM potatoes, while control of the potato beetle was the same as that of non-GM potatoes.

Sugar beet Sugar beet was included in only one conventional model rotation (Table 7). The GM scenario deviated from the baseline by direct drilling and by a different use pattern of herbicides. In the baseline, a full dose was assumed to be applied pre-emergence, and three split applications (half doses) were assumed post-emergence. In the GM scenario, the three split applications were replaced by one full dose of glufosinate. The ideotype GM sugar beet is also resistant to the BNYVV, which causes "rhizomania". Because all varieties from the Swiss list of recommended varieties are resistant to rhizomania, this does not entail any changes in management practice. Model rotation no 5 is very narrow. In this rotation, nematodes other than BNYVV might cause damage in the longer term.

Soybean Soy is part of the rotation in the DOC trial but is generally of little importance in Swiss agriculture. It was therefore included in only one organic model rotation (Table 8). 
Table 4 Model management practices for maize

\begin{tabular}{|c|c|c|}
\hline Date & Baseline scenario with non-GM maize & GM scenario with $\mathrm{HT}_{\mathrm{glu}}-\mathrm{Bt}$ maize \\
\hline \multicolumn{3}{|c|}{ Integrated/conventional model rotations (no 3, 4, and 6) } \\
\hline Mid-April & Manure $(30 \mathrm{t})$ & (See non-GM maize) \\
\hline Mid-May & Herbicide: "Basta" (glufosinate) ${ }^{\mathrm{a}}$ & (See non-GM maize) \\
\hline End of May & Cultivating, harrowing, sowing & Direct drilling \\
\hline Mid-June & Post-emergence herbicide: "Basagran” (bentazone) & $\begin{array}{l}\text { Rotations no } 3 \text { and 4: herbicide: "Basta" (glufosinate) } \\
\text { Rotation no 6: herbicide: "Basta" (glufosinate) or } \\
\text { "RoundUp" (glyphosate) (alternating each year) }\end{array}$ \\
\hline Mid-June & Slurry $\left(20 \mathrm{~m}^{3}\right)$ & (See non-GM maize) \\
\hline Early July & $\begin{array}{l}\text { Control of corn borer": release of Trichogramma } \\
\text { brassicae ("Tricho-Fix") }\end{array}$ & No treatment \\
\hline Early July & Slurry $\left(20 \mathrm{~m}^{3}\right)$ & (See non-GM maize) \\
\hline \multirow[t]{2}{*}{ End of September } & Rotations no 3 and 4: Harvest maize for silage (yield $175 \mathrm{dt} D M$ ) & Harvest: see non-GM maize \\
\hline & Afterwards: stubble mulching (against Fusarium and corn borer) & Afterwards: stubble mulching (against Fusarium) \\
\hline \multirow[t]{2}{*}{ Mid-October } & Rotation no 6: Harvest maize for grains (yield 95 dt DM) & Harvest maize for grains (yield 99 dt DM) \\
\hline & Afterwards: stubble mulching (against Fusarium and corn borer) & Afterwards: stubble mulching (against Fusarium) \\
\hline \multicolumn{3}{|c|}{ Organic model rotations (no 1 and 2) } \\
\hline Mid-April & Manure (35 t) & (See non-GM maize) \\
\hline Early May & Plowing, rolling & (See non-GM maize) \\
\hline Mid-May & Slurry $\left(25 \mathrm{~m}^{3}\right)$ & (See non-GM maize) \\
\hline End of May & Harrowing, sowing (re-sowing in case of crow damage) & (See non-GM maize) \\
\hline End of June & Harrow & (See non-GM maize) \\
\hline Early July* & $\begin{array}{l}\text { Control of corn borer": release of Trichogramma brassicae } \\
\text { ("Tricho-Fix") }\end{array}$ & No treatment \\
\hline Early July & Slurry $\left(25 \mathrm{~m}^{3}\right)$ & (See non-GM maize) \\
\hline End of September & Harvest maize for silage (yield $160 \mathrm{dt} \mathrm{DM}$ ) & (See non-GM maize) \\
\hline Early October & Stubble mulching (against Fusarium and corn borer) & Stubble mulching (against Fusarium) \\
\hline
\end{tabular}

In rotation no $6, \mathrm{Ht}_{\text {glu }}$ and $\mathrm{HT}_{\text {gly }}$ maize alternate each year in order to manage resistance of weeds. In rotations $1-4$, maize is produced for silage; in rotation no 6, maize is produced for grains. For the GM scenarios, only those management practices are explicitly described which differ from the non-GM scenarios

$D M$ dry matter

${ }^{\text {a }}$ In the sensitivity analyses, either a second release of Trichogramma or an insecticide application instead of a release of Trichogramma was assumed

Because the trait of herbicide tolerance has no value in the absence of herbicides, GM soy was not included in the organic GM scenarios (such as GM wheat).

Grass/clover Grass/clover was included only in the organic model rotations. It was always assumed for two consecutive years (Table 9). No GM varieties were assumed, and management practices were identical for the baseline and GM scenarios.

Catch crop Catch crops were included only in the integrated and conventional model rotations (Table 9). No GM varieties were assumed, and management practices were identical for the baseline and GM scenarios.

Green manure Green manures were included only in the organic model rotations (Table 9). No GM varieties were assumed for green manures.
3.6 Agronomic assumptions for the model horticultural farm

The model horticultural farm (10 ha) was also assumed to be located in the Swiss plateau. The model orchard was assumed to be managed according to integrated or to organic farming practices, as conventional fruit production is virtually absent in Switzerland.

\subsubsection{Assumptions for the model scenarios}

GM cultivars were assumed to be available for the two major apple varieties Gala and Braeburn. For the other apple varieties and for pears, GM cultivars were assumed not to be available. Two GM scenarios were investigated: in scenario 1, GM apples were resistant to scab only (FR apples), while in scenario 2, GM apples were resistant to scab and fire blight (FR-BR apples). 
Table 5 Model management practices for wheat

\begin{tabular}{|c|c|c|}
\hline Date & Baseline scenario with non-GM wheat & GM scenario with $\mathrm{HT}_{\text {gly }}$ wheat \\
\hline \multicolumn{3}{|c|}{ Integrated/conventional model rotations (no 3-5) } \\
\hline Mid-October & PKMg-fertilization $(60 / 100 / 15)$ & (See non-GM wheat) \\
\hline End of October & Rotary harrow, sowing & Direct drilling \\
\hline Early March & $\begin{array}{l}\text { Herbicide mix against monocots and dicots: "Husar" (iodosulfuron-methyl } \\
\text { sodium)+"Rasantan" (amidosulfuron/bromoxynil/diflufenican) }\end{array}$ & Herbicide: "RoundUp" (glyphosate) \\
\hline Early March & $\mathrm{N}$-fertilization $(40)$ & (See non-GM wheat) \\
\hline End of March & No micronutrient fertilization & Mn fertilization \\
\hline Mid-April & $\mathrm{N}$-fertilization $(60)$ & (See non-GM wheat) \\
\hline Mid-April & Growth regulator: "Cerone" (ethephone) & (See non-GM wheat) \\
\hline Mid-May & $\mathrm{N}$-fertilization $(40)$ & (See non-GM wheat) \\
\hline Mid-May & Fungicide against foliar diseases: "Daconil 500" (chlorothalonil) & (See non-GM wheat) \\
\hline Mid-June & Fungicide against Fusarium: "Proline" (prothioconazole) & (See non-GM wheat) \\
\hline End of July & Grain harvest (60 dt), straw harvest, stubble mulching & (See non-GM wheat) \\
\hline \multicolumn{3}{|c|}{ Organic model rotations (no 1 and 2) } \\
\hline Early October & Plowing & (No use of HT wheat in organic rotations) \\
\hline Mid-October & Manure ( $25 \mathrm{t}$; except after maize), harrowing & \\
\hline End of October & Sowing & \\
\hline Early March & Slurry $\left(30 \mathrm{~m}^{3}\right)$ & \\
\hline Early April & Slurry $\left(20 \mathrm{~m}^{3}\right)$ & \\
\hline Mid-April & Harrowing & \\
\hline End of July & Grain harvest (50 dt), straw harvest, stubble mulching & \\
\hline Early August & Harrow & \\
\hline
\end{tabular}

For details, see Table 4. Note that in the GM scenarios, HT wheat in not grown in the organic rotations, because this trait has no value in the absence of herbicides

For the purposes of modeling, all apple varieties (whether non-GM or GM) were classified as one of four ideotypes (=trait combinations): (1) scab and fire blight susceptible; (2) scab resistant and fire blight susceptible; (3) scab susceptible and fire blight resistant; and (4) scab and fire blight resistant (Table 10). Intermediate levels of resistance were not considered. For example, Pinova was classified as fire blight-resistant, even though it would be more correctly described as having low susceptibility.

Assumptions with respect to scab The model assumed that (1) the fungicide spraying scheme and (2) the proportion of marketable yield differed for scab-susceptible and scabresistant varieties.

Assumptions with respect to fire blight The model assumed that (1) the bactericide spraying scheme, (2) the labor for sanitation pruning, and (3) tree survival differed for fire blight-susceptible and -resistant varieties.

The spraying schemes are described in the section on agronomic assumptions and are shown in Tables 12 and 13. The assumptions regarding marketable yield, sanitation pruning, and tree survival are described in the section on economic assumptions and shown in Tables 20 and 21.

\subsubsection{Varietal composition of the model orchards}

The varietal composition of the model orchards was determined in the agronomy workshops. The composition of taste groups and ripening times was adjusted to the proportions for integrated and organic orchards in Switzerland. The model varieties were typical representatives with respect to taste groups and ripening times, but they could be substituted by different varieties with similar properties (e.g., Maigold could have replaced Golden Delicious). All model orchards were assumed to contain 9 ha of apples and 1 ha of pears. Because no GM varieties were assumed to be available for pears, the analysis focused exclusively on the 9 ha planted with apple trees. Note that the model orchards may also contain scabresistant (non-GM) varieties in the baseline scenario. Similarly, there may be a certain proportion of susceptible varieties in the GM scenarios (see Tables 10 and 11).

Organic model orchard The orchard was assumed to contain "equilibrated to sweet", "spicy to tart" and "predominantly tart" apples. Typical representatives of each flavor group were selected and their areas adjusted to the Swiss organic apple market. The proportion of scab-resistant varieties in the baseline scenario was $55 \%$. This is somewhat higher than the 
Table 6 Model management practices for potato

\begin{tabular}{|c|c|c|}
\hline Date & Baseline scenario with non-GM potato & GM scenario with FR-NR-Bt potato \\
\hline \multicolumn{3}{|c|}{ Integrated model rotation (no 3) } \\
\hline Early April & NPK-fertilization $(70 / 20 / 100)$ & (See non-GM potato) \\
\hline Mid-April & Manure (25 t), plow, harrow & (See non-GM potato) \\
\hline Mid-April & Plow, harrow, planting & (See non-GM potato) \\
\hline Early May & Herbicide: "Condoral" (metribuzine) & (See non-GM potato) \\
\hline Mid-May & Hoeing, harrowing, ridging & (See non-GM potato) \\
\hline End of May & Contact action fungicide a: "Dithane Neotec" (mancozeb) & $(\text { See non-GM potato })^{\mathrm{b}}$ \\
\hline Early June & Hoeing, ridging & (See non-GM potato) \\
\hline Early June & Systemic fungicidea: "Consento" (fenamidone and propamocarb-hydrochloride) & No treatment \\
\hline Early - Mid- June & Systemic fungicidea: "Consento" & No treatment \\
\hline Mid-June & Control of potato beetles, every third year: "Nomolt" (teflubenzurone) & No treatment \\
\hline June & Irrigation $2 \times 20 \mathrm{~mm}$ & (See non-GM potato) \\
\hline Mid-June & Systemic fungicide ${ }^{a}$ : "Consento" & $(\text { See non-GM potato })^{\mathrm{b}}$ \\
\hline End of June & Partially systemic fungicidea: "Acrobat MZ WG" (dimethomorph and mancozeb) & No treatment \\
\hline Early July & Partially systemic fungicide ${ }^{\mathrm{a}}$ : "Acrobat MZ WG" & $(\text { See non-GM potato })^{\mathrm{b}}$ \\
\hline Mid-July & Contact action fungicide": "Dithane Neotec" & No treatment \\
\hline End of July & Contact action fungicide": "Dithane Neotec" & No treatment \\
\hline Early August & Chemical haulm destruction: "Spotlight" (carfentrazone-ethyl) & (See non-GM potato) \\
\hline Mid-August & Harvest (yield $450 \mathrm{dt}$, of which $80 \%$ is marketable) & (See non-GM potato) \\
\hline \multicolumn{3}{|c|}{ Organic model rotation (no 1) } \\
\hline Mid-March & Plowing & (See non-GM potato) \\
\hline Early April & Slurry $\left(30 \mathrm{~m}^{3}\right)$ & (See non-gm potato) \\
\hline Early April & Potassium sulfate (100 kg) & (See non-gm potato) \\
\hline Early April & Harrow & (See non-GM potato) \\
\hline Mid-April & Rotary harrow, planting & (See non-GM potato) \\
\hline Mid-April & Organic $\mathrm{N}$ fertilizer $(30 \mathrm{~kg} \mathrm{~N})$ & (See non-GM potato) \\
\hline Early May & Hoeing, harrowing, ridging & (See non-GM potato) \\
\hline Mid-May & Slurry $\left(30 \mathrm{~m}^{3}\right)$ & (See non-GM potato) \\
\hline Mid-May & Hoeing, harrowing, ridging & (See non-GM potato) \\
\hline End of May & Slurry $\left(15 \mathrm{~m}^{3}\right)$ & (See non-GM potato) \\
\hline End of May & Fungicidea: "Cuprofix" (copper oxychloride) & No treatment \\
\hline Early June & Hoeing, ridging & (See non-GM potato) \\
\hline Early June & Fungicide": "Cuprofix" & $(\text { See non-GM potato })^{\mathrm{b}}$ \\
\hline Mid-June & Control of potato beetle: "Novodor" (Bacillus thuringiensis var. tenebrionis) & No treatment \\
\hline Mid-June & Fungicide a: "Cuprofix" & $(\text { See non-GM potato })^{\mathrm{b}}$ \\
\hline End of June & Control of potato beetle: "Novodor" & No treatment \\
\hline June & Irrigation $2 \times 20 \mathrm{~mm}$ & (See non-GM potato) \\
\hline End of June & Fungicide": "Cuprofix" & $(\text { See non-GM potato })^{\mathrm{b}}$ \\
\hline Early July & Fungicide": "Cuprofix" & No treatment \\
\hline Mid-July & Fungicide ${ }^{a}$ : "Cuprofix" & No treatment \\
\hline Early August & Mechanical haulm destruction (flailing) & (See non-GM potato) \\
\hline Mid-August & Harvest (yield $250 \mathrm{dt}$ ), of which $70 \%$ is marketable & $\begin{array}{l}\text { Harvest (yield } 275 \mathrm{dt} \text { ), of } \\
\text { which } 80 \% \text { is marketable }\end{array}$ \\
\hline
\end{tabular}

For details, see Table 4

${ }^{a}$ Use of fungicides mainly for control of late blight

${ }^{\mathrm{b}}$ Use of fungicides for control of $A$. solanii, and for resistance management of late blight

The use of copper fungicides is limited to $4 \mathrm{~kg} / \mathrm{ha}$ pure copper (=8 kg/ha "Cuprofix"). Thus, it is assumed that $1.33 \mathrm{~kg} / \mathrm{ha}$ "Cuprofix" are used in each application (in the non-GM as well as the GM scenario) 
Table 7 Model management practices for sugar beet

\begin{tabular}{|c|c|c|}
\hline Date & Baseline scenario with non-GM sugar beet & GM scenario with $\mathrm{HT}_{\text {glu }}-\mathrm{VR}$ sugar beet \\
\hline \multicolumn{3}{|c|}{ Conventional model rotation (no 5) } \\
\hline Early March & PKMg-fertilization $(85 / 465 / 70)$ & (See non-GM sugar beet) \\
\hline Early March & Herbicide: "RoundUp" (glyphosate) & (See non-GM sugar beet) \\
\hline End of March & Cultivating, harrowing, sowing & $\begin{array}{l}\text { Direct drilling ; Herbicide: "Basta" } \\
\text { (glufosinate; full dose) }\end{array}$ \\
\hline Early April & $\mathrm{N}$-fertilization (40) & (see non-GM sugar beet) \\
\hline Mid-April & $\begin{array}{l}\text { Post-emergence herbicide (first half-dose): "Betanal" (desmedipham, } \\
\text { ethofumesate, phenmedipham) }\end{array}$ & No treatment \\
\hline End of April & Molluscicide: "Metarex" (metaldehyde) & (See non-GM sugar beet) \\
\hline Early May & $\mathrm{N}$-fertilization $(60)$ & (See non-GM sugar beet) \\
\hline Early May & Post-emergence herbicide (second half-dose): "Betanal" & Herbicide: "Basta" (glufosinate; full dose) \\
\hline Early June & Post-emergence herbicide (third half-dose): "Betanal" & No treatment \\
\hline Mid-June & Insecticide against aphids: "Pirimor" (pirimicarb) & (See non-GM sugar beet) \\
\hline Early August & Fungicide: “Avenir” (fenpropimorph, difenoconazole) & (See non-GM sugar beet) \\
\hline Mid-October & Harvest (yield 75 t) & (See non-GM sugar beet) \\
\hline
\end{tabular}

For details, see Table 4. Sugar beet was not included in the organic model rotations

${ }^{a}$ Direct drilling is possible only under good soil conditions (otherwise: see non-GM sugar beet)

current percentage of approximately $35 \%$ (Weibel and Leder 2007) but may be a realistic assumption for the study period. In scenario 1, the following changes were assumed: (1) FR Gala and FR Braeburn would replace their non-GM equivalents, as well as Retina and Ariwa; (2) due to these replacements, a large proportion of the orchard would be subject to a reduced scab spraying program, and the grower was assumed to give up Idared and Boskoop. Nevertheless, Pinova, Topaz, and Otava would remain in the model orchard: Pinova is robust against fire blight and has more acidity than Gala. Topaz has a more intense taste than Braeburn and matures earlier. Otava would

Table 8 Model management practices for soy

\begin{tabular}{lll}
\hline Date & $\begin{array}{l}\text { Baseline scenario } \\
\text { with non-GM soy }\end{array}$ & GM scenario with HT soy \\
\hline
\end{tabular}

Organic model rotation (no 1)

$\begin{array}{lll}\text { Early May } & \text { Plowing } & \begin{array}{c}\text { (No use of HT soy } \\ \text { in organic rotations) }\end{array} \\ \begin{array}{l}\text { Early May } \\ \text { Early June }\end{array} & \begin{array}{l}\text { Rotary harrow, sowing } \\ \text { Marrowing, hoeing }\end{array} \\ \text { Mid June } & \begin{array}{l}\text { Hoeing }^{\text {b }} \\ \text { End of October }\end{array} & \begin{array}{c}\text { Harvest (yield } 21 \mathrm{dt} \text { ), } \\ \text { straw mulching }\end{array}\end{array}$

For details, see Table 4. Soy was only included in the organic model rotations. Note that HT soy in not grown in the organic rotations, because this trait has no value in the absence of herbicides

${ }^{\text {a }}$ Seed inoculated with rhizobia

${ }^{\mathrm{b}}$ In the DOC trial, organic soy is hand-weeded. In this study, it is assumed that hand-weeding can be replaced by the harrow remain in the model orchard as the only predominantly tart apple. In scenario 2, we assumed that FR-BR Gala and FR-BR Braeburn replace not only their counterparts that are susceptible to fire blight but also Topaz and Otava. Only Pinova would remain in the model orchard, because it is robust against fire blight and has more acidity than Gala.

Integrated model orchard The orchard was assumed to contain "equilibrated to sweet" and "spicy to tart", but no "predominantly tart" apples. Within each taste group, several varieties were assumed to be grown for the following reasons: (1) the market demands several varieties with well-known names and slightly different properties (acid content, consistency of the flesh); (2) varied ripening times reduce labor peaks during harvesting; and (3) varietal diversity reduces risks for the grower. No scab-resistant varieties were assumed for the baseline scenario, which reflects their lack of importance in Swiss integrated apple growing. In scenario 1 , the following changes were assumed: (1) FR Gala and FR Braeburn would replace their non-GM equivalents; (2) due to these replacements, a large proportion of the orchard would be subject to a reduced scab spraying program, and the grower was assumed to give up Golden Delicious in favor of FR Gala and FR Braeburn. Nevertheless, Jonagold and Kanzi would remain in the model orchard due to market demand. Jonagold is more acidic and has a firmer flesh than Gala, and Kanzi is a club variety with a separate market of its own. In scenario 2, FR-BR Gala and FR-BR Braeburn would replace their counterparts that are susceptible to fire blight. Jonagold and Kanzi would remain in the model orchard for the reasons given for scenario 1 . 
Table 9 Model management practices for crops without GM varieties (grass/clover, catch crops and green manure)

For details, see Table 4. Grass/clover and green manure were assumed only for organic model rotations, catch crops only for integrated and conventional model rotations. Grass/clover was always assumed for two consecutive years. In all cases, management practices are identical for baseline and GM scenarios

\begin{tabular}{ll}
\hline Date & Baseline and GM scenario \\
\hline Grass/clover in organic model rotations (no 1 and 2$)$ \\
Early August & Manure (10 t), harrow (first year only) \\
Early Aug. & Rotary harrow, sowing, rolling (first year only) \\
Early March & Slurry $\left(30 \mathrm{~m}^{3}\right)$ \\
Early May & Cut 1 \\
Mid-May & Slurry $\left(20 \mathrm{~m}^{3}\right)$ \\
End of May & Cut 2 \\
End of July & Cut 3 \\
Mid-September & Cut 4 \\
End of October & Cut 5 (total harvest first year $85 \mathrm{dt} \mathrm{DM;} \mathrm{second} \mathrm{year} 100 \mathrm{dt}$ DM) \\
Catch crops in integrated/conventional model rotations (no 3 and 4$)$ \\
Mid-August & Harrowing, sowing, rolling \\
Mid-August & NPKMg-fertilization (30/25/90/10) \\
Mid-March & Harvest of catch crop (25 dt DM) \\
Green manure in organic model rotations (no 1) & \\
Mid-August & Slurry (30 $\mathrm{m}^{3}$ ) (after wheat, but not after potatoes) \\
Mid-August & Harrowing, sowing (legumes), rolling \\
Mid-March & Mulching
\end{tabular}

\subsubsection{Model plant protection schemes}

Plant protection Model plant protection schemes were defined for the integrated and the organic model orchards (Tables 12 and 13). Applications of herbicides, growth regulators, and insecticides were identical for all resistance traits. Fungicide applications varied with scab resistance, and bactericide applications varied with fire blight resistance. Fewer fungicide applications are made on scabresistant apples. However, not all fungicide sprays were left out, (1) as a resistance management strategy to counter the scab pathogen and (2) to control mildew and sooty blotch. These latter two diseases would normally be controlled as a side effect of the fungicide treatments for scab.

\section{Economic calculations and socio-economic assessments}

\subsection{Economic calculations for the model arable crops} and rotations

In order to analyze the economic impact of introducing GM crops in conventional, integrated, and organic
Table 10 Varietal composition of apples in the model orchards

The model varieties and their surface are given (in hectare) for each scenario and production system. Resistance traits are indicated in brackets (abbreviations are explained in Table 11). Varieties are classified as either susceptible or resistant, without intermediate values (see text)

\begin{tabular}{llllll}
\hline $\begin{array}{l}\text { Baseline scenario } \\
\text { Variety }\end{array}$ & ha & $\begin{array}{l}\text { GM scenario 1 } \\
\text { Variety }\end{array}$ & $\begin{array}{l}\text { GM scenario 2 } \\
\text { Variety }\end{array}$ & ha \\
\hline $\begin{array}{l}\text { Organic model orchards } \\
\text { Gala (ss) }\end{array}$ & 2 & FR Gala (rs) & 3 & FR-BR Gala (rr) & 4 \\
Pinova (sr) & 1 & Pinova (sr) & 1 & Pinova (sr) & 1 \\
Idared (ss) & 1 & Topaz (rs) & 2 & FR-BR Braeburn (rr) & 4 \\
Topaz (rs) & 2 & FR Braeburn (rs) & 2 & & \\
Retina (rs) & 0.5 & Otava (rs) & 1 & & \\
Ariwa (rr) & 0.5 & & & & \\
Otava (rs) & 1 & & & & \\
Boskoop (rr) & 1 & & & & \\
Integrated model orchards & & & & & \\
Gala (ss) & 3 & FR Gala (rs) & 4 & Fonagold (ss) & \\
Golden Delicious (ss) & 2 & Jonagold (ss) & 1 & FR-BR Braeburn (rr) & 3 \\
Jonagold (ss) & 1 & FR Braeburn (rs) & 3 & \\
Braeburn (ss) & 2 & Kanzi (ss) & 1 & Kanzi (ss) \\
Kanzi (ss) & 1 & & & & 1 \\
\hline
\end{tabular}


Table 11 Composition of the model orchards with respect to resistance traits

For each combination of scab and fire blight-resistance traits (="ideotype"), the surface (in hectare) and the percentage in the apple segment of the model orchard ( $=9 \mathrm{ha})$ is given. The surface for each trait combination is equal to the sum for all varieties with these traits (see Table 10)

\begin{tabular}{|c|c|c|c|c|}
\hline \multicolumn{2}{|c|}{ Resistance traits, ideotype } & $\begin{array}{l}\text { Baseline } \\
\text { scenario }\end{array}$ & $\begin{array}{l}\text { GM scenario } \\
1\end{array}$ & $\begin{array}{l}\text { GM scenario } \\
2\end{array}$ \\
\hline \multicolumn{5}{|c|}{ Organic model orchard } \\
\hline ss & Scab susceptible and fire blight susceptible & 3 ha $(33 \%)$ & - & - \\
\hline rs & Scab resistant and fire blight susceptible & 3.5 ha $(39 \%)$ & 8 ha $(89 \%)$ & - \\
\hline $\mathrm{sr}$ & Scab susceptible and fire blight resistant & 1 ha $(11 \%)$ & 1 ha $(11 \%)$ & 1 ha $(11 \%)$ \\
\hline $\mathrm{rr}$ & Scab resistant and fire blight resistant & 1.5 ha $(17 \%)$ & - & 8 ha $(89 \%)$ \\
\hline \multicolumn{5}{|c|}{ Integrated model orchard } \\
\hline ss & Scab susceptible and fire blight susceptible & 9 ha $(100 \%)$ & 2 ha $(22 \%)$ & 2 ha $(22 \%)$ \\
\hline rs & Scab resistant and fire blight susceptible & - & 7 ha $(78 \%)$ & - \\
\hline $\mathrm{rr}$ & Scab resistant and fire blight resistant & - & - & - \\
\hline
\end{tabular}

rotations, we adapted an established heuristic economic simulation model developed in the EU-funded project "SIGMEA" (Copeland et al. 2007). The model calculates the additional benefits and the additional costs for each GM crop compared to the non-GM alternative. The model output is the change in (1) total direct costs, including the labor costs of paid and family labor and (2) the gross margin (total revenues minus direct costs) of the crops and of the entire crop rotation including direct payments. Based on margins for each non-GM/ GM crop, we calculated net margins for the model rotations.

Benefits and costs were calculated according to the detailed specifications elaborated in the agronomy workshops (see "Section 3.5"). The model considers the following variables:

- unequal seed costs for non-GM and GM crops

- altered weed management in HT crops (tillage in non-HT crops vs. direct drilling in HT crops; altered herbicide use)

- micronutrient fertilization in conjunction with glyphosate treatment of HT crops

- $\quad$ altered control of the European corn borer in non-Bt vs. Bt maize

- different yield for non-GM and GM crops in maize for grains and in organic potatoes

\subsubsection{Assumptions regarding production costs and returns}

Seed costs Costs for non-GM seeds were based on Meyer et al. (2008). For GM seeds, we assumed a "technology fee" or "price premium" of $30 \%$ on top of the conventional seed price for all crops. This is comparable to published figures: Menrad et al. (2009) assume a technology fee of 30\% GM wheat; Kasamba and Copeland (2007) and Daems et al. (2007) mention a technology fee of $30 \%$ for GM oilseed rape; for Bt maize in Spain, Gómez-Barbero and Rodruigez-Cerezo (2007) report additional seed costs of 4-21\%. For Bt maize in Germany, Reitmeier et al. (2006) calculated additional seed costs of $34 \%$. In the sensitivity analyses, the price premium was varied by $\pm 20 \%$, i.e., 24 and $36 \%$ (see below).

Costs for machinery and labor Variable costs for the use of machinery were based on Meyer et al. (2008). The corresponding labor requirements were based on KTBL (2008) and Meyer et al. (2008). Costs for hired machinery and labor were based on Schoch (2009). In order to keep the non-GM and GM scenarios as comparable as possible, we assumed that direct drilling, planting, and harvesting is done by professional operators (hired machinery and labor). Hourly wages were set at $37 \mathrm{CHF} / \mathrm{h}$ for paid labor and 27 $\mathrm{CHF} / \mathrm{h}$ for family farm labor (Schoch 2009). Where data for Switzerland were not available, data from non-Swiss sources were used and converted on the basis of the EUROSTAT price indices for agricultural inputs and machinery (EUROSTAT 2009).

Costs for inputs Costs for fertilizers and plant protection products were based on Schoch (2009). Where products were not listed in Schoch (2009), documentation material provided by traders was consulted. For copper fungicides used in organic potatoes, product costs were adjusted to the limited amount of $4 \mathrm{~kg} / \mathrm{ha}$ pure copper per year.

Yield The yield levels assumed for each crop and production system were part of the agronomic assumptions shown in Tables 4, 5, 6, 7, 8, and 9. Prices for food and feed were based on Schoch (2009). Farm-internal use of feed (maize for silage, catch crops, and grass/clover) was calculated at market prices.

Direct payments For the integrated model farms, general direct payments are 1,660 $\mathrm{CHF} / \mathrm{ha}$. The organic model farms receive general direct payments of 1,660 CHF/ha plus organic area payments of $800 \mathrm{CHF} / \mathrm{ha}$. For wheat, they receive "Extenso" payments of $400 \mathrm{CHF} / \mathrm{ha}$ and for soy area payments of 1,000 CHF/ha. By definition, the conventional model farms are not eligible for direct payments. 
Table 12 Plant protection scheme for the organic model orchard

\begin{tabular}{|c|c|c|c|c|c|c|}
\hline \multirow[b]{2}{*}{ Date } & \multirow[b]{2}{*}{ Stage } & \multirow[b]{2}{*}{ Targets } & \multicolumn{4}{|c|}{ Resistance trait ideotype } \\
\hline & & & ss & rs & $\mathrm{sr}$ & $\mathrm{rr}$ \\
\hline Apr 3 & \multirow[t]{2}{*}{$\mathrm{C} 3$} & $\mathrm{Scab}^{\mathrm{a}}$ & Ko & - & Ko & - \\
\hline Apr 8 & & $\mathrm{Scab}^{\mathrm{a}}$ & Ko & - & Ko & - \\
\hline Apr 13 & $\mathrm{D}$ & $\mathrm{Scab}^{\mathrm{a}}$ & Ko & - & Ko & - \\
\hline Apr 18 & $\mathrm{E}$ & $\mathrm{Scab}^{\mathrm{b}}$ and mildew & $\mathrm{S}+\mathrm{My}$ & $\mathrm{S}+\mathrm{My}$ & $\mathrm{S}+\mathrm{My}$ & $\mathrm{S}+\mathrm{My}$ \\
\hline Apr 22 & \multirow[t]{2}{*}{ E2 } & $\mathrm{Scab}^{\mathrm{a}}$ and mildew & $\mathrm{S}+\mathrm{My}$ & - & $\mathrm{S}+\mathrm{My}$ & - \\
\hline Apr 23 & & Rosy apple aphid & NA & NA & NA & NA \\
\hline Apr 24 & \multirow[t]{4}{*}{$\mathrm{F}$} & $\mathrm{Scab}^{\mathrm{b}}$ and mildew & $\mathrm{S}+\mathrm{My}$ & $\mathrm{S}+\mathrm{My}$ & $\mathrm{S}+\mathrm{My}$ & $\mathrm{S}+\mathrm{My}$ \\
\hline Apr 29 & & Codling moth & Iso $^{\mathrm{a}}$ & Iso $^{a}$ & Iso $^{a}$ & Iso $^{\mathrm{a}}$ \\
\hline Apr 29 & & $\mathrm{Scab}^{\mathrm{b}}$ and mildew & $\mathrm{S}+\mathrm{My}$ & $\mathrm{S}+\mathrm{My}$ & $\mathrm{S}+\mathrm{My}$ & $\mathrm{S}+\mathrm{My}$ \\
\hline Apr 29 & & Fire blight & $\mathrm{BP}$ & $\mathrm{BP}$ & - & - \\
\hline May 3 & \multirow[t]{2}{*}{ G } & $\mathrm{Scab}^{\mathrm{a}}$ and mildew & $\mathrm{S}+\mathrm{My}$ & - & $\mathrm{S}+\mathrm{My}$ & - \\
\hline May 3 & & Fire blight & $\mathrm{BP}$ & $\mathrm{BP}$ & - & - \\
\hline May 8 & \multirow[t]{5}{*}{$\mathrm{H}$} & $\mathrm{Scab}^{\mathrm{b}}$ and mildew & $\mathrm{S}+\mathrm{My}$ & $\mathrm{S}+\mathrm{My}$ & $\mathrm{S}+\mathrm{My}$ & $\mathrm{S}+\mathrm{My}$ \\
\hline May 8 & & Fire blight & $\mathrm{BP}$ & $\mathrm{BP}$ & - & - \\
\hline May 13 & & $\mathrm{Scab}^{\mathrm{b}}$ and mildew; sawfly & $\mathrm{S}+\mathrm{My}+\mathrm{Qu}$ & $\mathrm{S}+\mathrm{My}+\mathrm{Qu}$ & $\mathrm{S}+\mathrm{My}+\mathrm{Qu}$ & $\mathrm{S}+\mathrm{My}+\mathrm{Qu}$ \\
\hline May 19 & & $\mathrm{Scab}^{\mathrm{a}}$ and mildew & $\mathrm{S}+\mathrm{My}$ & - & $\mathrm{S}+\mathrm{My}$ & - \\
\hline May 27 & & $\mathrm{Scab}^{\mathrm{a}}$ and mildew & $\mathrm{S}+\mathrm{My}$ & - & $\mathrm{S}+\mathrm{My}$ & - \\
\hline June 2 & \multirow[t]{2}{*}{ I } & $\mathrm{Scab}^{\mathrm{a}}$ and mildew; codling moth & $\mathrm{S}+\mathrm{Ma}$ & $\mathrm{Ma}$ & $\mathrm{S}+\mathrm{Ma}$ & Ma \\
\hline June 12 & & $\mathrm{Scab}^{\mathrm{a}}$, mildew and sooty blotch & $\mathrm{S}$ & $\mathrm{Ar}$ & $\mathrm{S}$ & $\mathrm{Ar}$ \\
\hline June 21 & \multirow[t]{10}{*}{$\mathrm{J}$} & $\mathrm{Scab}^{\mathrm{a}}$ and mildew & $\mathrm{S}$ & - & $\mathrm{S}$ & - \\
\hline June 29 & & $\mathrm{Scab}^{\mathrm{a}}$, mildew and sooty blotch & $\mathrm{S}+\mathrm{Ar}$ & $\mathrm{Ar}$ & $\mathrm{S}+\mathrm{Ar}$ & $\mathrm{Ar}$ \\
\hline July 8 & & $\mathrm{Scab}^{\mathrm{a}}$ and mildew & $\mathrm{S}$ & - & $\mathrm{S}$ & - \\
\hline July 14 & & $\mathrm{Scab}^{\mathrm{a}}$, mildew and sooty blotch & $\mathrm{S}+\mathrm{Ar}$ & $\mathrm{Ar}$ & $\mathrm{S}+\mathrm{Ar}$ & $\mathrm{Ar}$ \\
\hline July 22 & & $\mathrm{Scab}^{\mathrm{a}}$ and mildew & $\mathrm{S}$ & - & $\mathrm{S}$ & - \\
\hline July 31 & & $\mathrm{Scab}^{\mathrm{a}}$, mildew and sooty blotch & $\mathrm{S}+\mathrm{Ar}$ & $\mathrm{Ar}$ & $\mathrm{S}+\mathrm{Ar}$ & $\mathrm{Ar}$ \\
\hline Aug 8 & & $\mathrm{Scab}^{\mathrm{a}}$ and mildew & $\mathrm{S}$ & - & $\mathrm{S}$ & - \\
\hline Aug 24 & & $\mathrm{Scab}^{\mathrm{a}}$, mildew and sooty blotch & $\mathrm{S}+\mathrm{Ar}$ & $\mathrm{Ar}$ & $\mathrm{S}+\mathrm{Ar}$ & $\mathrm{Ar}$ \\
\hline Sept 6 & & $\mathrm{Scab}^{\mathrm{a}}$ and mildew & $\mathrm{S}$ & - & $\mathrm{S}$ & - \\
\hline Sept 25 & & $\mathrm{Scab}^{\mathrm{a}}$, mildew and sooty blotch & $\mathrm{Ar}$ & $\mathrm{Ar}$ & $\mathrm{Ar}$ & $\mathrm{Ar}$ \\
\hline \multicolumn{3}{|c|}{ Number of spray passages } & 28 & 16 & 25 & 13 \\
\hline \multicolumn{3}{|c|}{ Distribution of pheromone dispensers } & 1 & 1 & 1 & 1 \\
\hline
\end{tabular}

Timing of pesticide applications (date, developmental stage), targets and pesticides used on different apple ideotypes (abbreviations are explained in Table 11). Each line represents a separate application (e.g., the treatments on May 3 against scab and against fire blight are not mixable). Kocide Opti is applied at a rate equivalent to $500 \mathrm{~g} / \mathrm{ha}$ of pure copper. Sulfur is applied at $0.2 \%$ in combination with Armicarb, otherwise at $>0.4 \%$. All other products are applied at the recommended rate

${ }^{\text {a }}$ Fungicide is used only for the purpose of scab control

${ }^{\mathrm{b}}$ Fungicide is used for the purpose of scab control on susceptible varieties and for resistance management on resistant varieties

Fungicides: Ko Kocide Opti (copper hydroxide); $S$ Schwefel Stulln (sulfur); My Myco-Sin (acidified clay); Ar Armicarb (potassium bicarbonate). Insecticides: NA NeemAzal-T/S (azadirachtine); Qu Quassan (quassia extract). Micro-organisms: BP BlossomProtect (Aureobasidium pullulans); Ma Madex 3 (granulosis virus). Pheromone dispensers: Iso Isomate-C Plus

\subsubsection{Production costs and returns in relation to agronomic management practices}

In a first step, the exact financial consequences of the management practices associated with each GM trait and crop were determined. For example, each pesticide spray passage implied variable machinery costs of $22.00 \mathrm{CHF} / \mathrm{ha}$ and required $0.9 \mathrm{~h}$ of labor (equivalent to $24.30 \mathrm{CHF} / \mathrm{ha}$ ). The product costs were added to this. Costs and returns were calculated as additional costs/returns, i.e., costs for GM crop - costs for non-GM crop (see Table 14). The additional production costs of GM crops as compared to non-GM crops varied 
Table 13 Plant protection scheme for the integrated model orchard

Resistance trait ideotype

\begin{tabular}{|c|c|c|c|c|c|c|}
\hline Date & Stage & Targets & ss & rs & $\mathrm{sr}$ & $\mathrm{rr}$ \\
\hline Apr 1 & & Apple blossom weevil & $\mathrm{Al}$ & $\mathrm{Al}$ & $\mathrm{Al}$ & $\mathrm{Al}$ \\
\hline Apr 4 & $\mathrm{C} 3$ & $\mathrm{Scab}^{\mathrm{a}}$ & De & - & De & - \\
\hline Apr 8 & & Apple blossom weevil & $\mathrm{Al}$ & $\mathrm{Al}$ & $\mathrm{Al}$ & $\mathrm{Al}$ \\
\hline Apr 13 & $\mathrm{D}$ & $\mathrm{Scab}^{\mathrm{b}}$ & $\mathrm{De}$ & De & De & De \\
\hline Apr 18 & $\mathrm{E}$ & $\mathrm{Scab}^{\mathrm{a}}$ and mildew & De & - & De & - \\
\hline Apr 22 & E2 & $\mathrm{Scab}^{\mathrm{b}}$ and mildew & De & De & De & $\mathrm{De}$ \\
\hline Apr 23 & & Rosy apple aphid & Py & Py & Py & Py \\
\hline Apr 24 & $\mathrm{~F}$ & $\mathrm{Scab}^{\mathrm{b}}$ and mildew & $\mathrm{Sli}+\mathrm{Ca}$ & $\mathrm{Sli}+\mathrm{Ca}$ & $\mathrm{Sli}+\mathrm{Ca}$ & $\mathrm{Sli}+\mathrm{Ca}$ \\
\hline Apr 25 & & Weeds & Ro & Ro & Ro & Ro \\
\hline Apr 29 & & $\mathrm{Scab}^{\mathrm{b}}$ and mildew; thinning & $\mathrm{Sli}+\mathrm{Ca}+\mathrm{Et}$ & $\mathrm{Sli}+\mathrm{Ca}+\mathrm{Et}$ & $\mathrm{Sli}+\mathrm{Ca}+\mathrm{Et}$ & $\mathrm{Sli}+\mathrm{Ca}+\mathrm{Et}$ \\
\hline Apr 29 & & Fire blight & Str & Str & - & - \\
\hline May 3 & G & Rust mites & $\mathrm{Ki}$ & $\mathrm{Ki}$ & $\mathrm{Ki}$ & $\mathrm{Ki}$ \\
\hline May 3 & & Fire blight & Str & Str & - & - \\
\hline May 8 & $\mathrm{H}$ & Aphids & Py & Py & Py & Py \\
\hline May 8 & & Fire blight & Reg & Reg & - & - \\
\hline May 13 & & Codling moth & $\mathrm{Al}$ & $\mathrm{Al}$ & $\mathrm{Al}$ & $\mathrm{Al}$ \\
\hline May 15 & & Weeds & $\mathrm{Ba}$ & $\mathrm{Ba}$ & $\mathrm{Ba}$ & $\mathrm{Ba}$ \\
\hline May 19 & & $\mathrm{Scab}^{\mathrm{a}}$ and mildew; thinning & $\mathrm{Ca}+\mathrm{Rh}$ & $\mathrm{Rh}$ & $\mathrm{Ca}+\mathrm{Rh}$ & $\mathrm{Rh}$ \\
\hline May 27 & & $\mathrm{Scab}^{\mathrm{b}}$ and mildew & $\mathrm{Ca}$ & $\mathrm{Ca}$ & $\mathrm{Ca}$ & $\mathrm{Ca}$ \\
\hline June 2 & I & $\mathrm{Scab}^{\mathrm{a}}$ and mildew & $\mathrm{Ca}$ & - & $\mathrm{Ca}$ & - \\
\hline June 12 & & $\mathrm{Scab}^{\mathrm{b}}$ and mildew & $\mathrm{Ca}$ & $\mathrm{Ca}$ & $\mathrm{Ca}$ & $\mathrm{Ca}$ \\
\hline June 21 & $\mathrm{~J}$ & Codling moth & $\mathrm{Ma}$ & $\mathrm{Ma}$ & $\mathrm{Ma}$ & $\mathrm{Ma}$ \\
\hline June 29 & & $\mathrm{Scab}^{\mathrm{b}}$ and mildew and sooty blotch; Codling moth & $\mathrm{Fli}+\mathrm{Ma}$ & $\mathrm{Fli}+\mathrm{Ma}$ & $\mathrm{Fli}+\mathrm{Ma}$ & $\mathrm{Fli}+\mathrm{Ma}$ \\
\hline July 14 & & $\mathrm{Scab}^{\mathrm{b}}$ and mildew and sooty blotch; Codling moth & $\mathrm{Fli}+\mathrm{Ma}$ & $\mathrm{Fli}+\mathrm{Ma}$ & $\mathrm{Fli}+\mathrm{Ma}$ & $\mathrm{Fli}+\mathrm{Ma}$ \\
\hline July 31 & & Codling moth & $\mathrm{Ma}$ & $\mathrm{Ma}$ & Ma & $\mathrm{Ma}$ \\
\hline Aug 8 & & $\mathrm{Scab}^{\mathrm{b}}$ and mildew and sooty blotch; Codling moth & $\mathrm{Fli}+\mathrm{Ma}$ & $\mathrm{Fli}+\mathrm{Ma}$ & $\mathrm{Fli}+\mathrm{Ma}$ & $\mathrm{Fli}+\mathrm{Ma}$ \\
\hline Sept 6 & & Codling moth & $\mathrm{Ma}$ & $\mathrm{Ma}$ & $\mathrm{Ma}$ & $\mathrm{Ma}$ \\
\hline Sept 25 & & $\mathrm{Scab}^{\mathrm{b}}$ and mildew and sooty blotch; Codling moth & $\mathrm{Fli}+\mathrm{Ca}$ & $\mathrm{Fli}+\mathrm{Ca}$ & $\mathrm{Fli}+\mathrm{Ca}$ & $\mathrm{Fli}+\mathrm{Ca}$ \\
\hline \multicolumn{3}{|c|}{ Number of spray passages } & 28 & 25 & 25 & 22 \\
\hline
\end{tabular}

For explanations, see Table 12. All products are applied at the recommended rate

Fungicides: Ca Captan 80 (captane); De Delan WG (dithianone); Fli Flint (trifloxystrobin); Sli Slick (difenoconazole). Bactericides: Reg Regalis (prohexadione-calcium); Str streptomycine. Insecticides: Al Alanto (thiacloprid); Ki Kiron (fenpyroximate); Py Pyrinex (clorpyrifos). Microorganisms: Ma Madex 3 (granulosis virus). Herbicides: Ba Basta (glufosinate); Ro Roundup (glyphosate). Growth regulators: Et Ethephon (ethephone); Rh Rhodofix (2-(1-naphthyl) acetic acid)

${ }^{a}$ Fungicide is used only for the purpose of scab control

${ }^{\mathrm{b}}$ Fungicide is used for the purpose of scab control on susceptible varieties and for resistance management on resistant varieties

between -116 CHF/ha (conventional grain maize) and +789 CHF/ha (organic potato).

\subsubsection{Profitability of individual crops}

In a second step, the total production costs and returns for individual non-GM and GM crops were calculated, using the established "gross margins" model for Switzerland (Meyer et al. 2008). Unlike this model, however, costs for farm family labor were added to the production costs. This resulted in a "net margin", which was calculated as yield+direct payments - production costs including labor costs (see Table 15).

Maize for silage The absolute net margins differed greatly between farming systems and were highest for organic and lowest for conventional maize. In all three farming systems, the net margins for GM and non-GM maize differed very little (maximum: +111 CHF/ha for GM maize).

Maize for grains Yield was similar to maize for silage, but production costs were much lower, because of the absence 
Table 14 Calculation of additional production costs and revenues for GM crops

\begin{tabular}{|c|c|c|c|}
\hline Crop & Production system & Management practices for GM crops & Add. costs/revenues \\
\hline \multirow[t]{3}{*}{ Maize (silage) } & \multirow[t]{3}{*}{ Organic } & Price premium on seeds & +129 \\
\hline & & Control of corn borer ${ }^{\mathrm{a}}$ & -141 \\
\hline & & Total additional costs ${ }^{\mathrm{b}}$ & -12 \\
\hline \multirow[t]{4}{*}{ Maize (silage) } & \multirow[t]{4}{*}{ Integrated, conventional } & Price premium on seeds & +90 \\
\hline & & Tillage system and weed control & -60 \\
\hline & & Control of corn borer ${ }^{a}$ & -141 \\
\hline & & Total additional costs ${ }^{\mathrm{b}}$ & -111 \\
\hline \multirow[t]{7}{*}{ Maize (grains) } & \multirow[t]{7}{*}{ Conventional } & Price premium on seeds & +82 \\
\hline & & Tillage system and weed control & -60 \\
\hline & & Control of corn borer ${ }^{\mathrm{a}}$ & -141 \\
\hline & & Insurance for higher yield & +3 \\
\hline & & Total additional costs ${ }^{\mathrm{b}}$ & -116 \\
\hline & & Increased yield & +146 \\
\hline & & Total additional returns & +146 \\
\hline Wheat & Organic & (no GM crops used) & 0 \\
\hline \multirow[t]{4}{*}{ Wheat } & \multirow[t]{4}{*}{ Integrated, conventional } & Price premium on seeds & +70 \\
\hline & & Tillage system and weed control & -97 \\
\hline & & Mn fertilization & +106 \\
\hline & & Total additional costs & +79 \\
\hline \multirow[t]{7}{*}{ Potato } & \multirow[t]{7}{*}{ Organic } & Price premium on seeds & +1175 \\
\hline & & Disease control & -229 \\
\hline & & Control of potato beetle & -248 \\
\hline & & Insurance for higher yield & +91 \\
\hline & & Total additional costs & +789 \\
\hline & & Increased yield and higher proportion of marketable yield & +4275 \\
\hline & & Total additional returns & +4275 \\
\hline \multirow[t]{4}{*}{ Potato } & \multirow[t]{4}{*}{ Integrated } & Price premium on seeds & +929 \\
\hline & & Disease control & -537 \\
\hline & & Control of potato beetle & -118 \\
\hline & & Total additional costs & +274 \\
\hline \multirow[t]{3}{*}{ Sugar beet } & \multirow[t]{3}{*}{ Conventional } & Price premium on seeds & +143 \\
\hline & & Tillage system and weed control & -176 \\
\hline & & Total additional costs ${ }^{\mathrm{b}}$ & -33 \\
\hline Soy & Organic & (No GM crops used) & 0 \\
\hline Grass/clover & Organic & (No GM crops used) & 0 \\
\hline Catch crop & Integrated, conventional & (No GM crops used) & 0 \\
\hline Green manure & Organic & (No GM crops used) & 0 \\
\hline
\end{tabular}

Additional costs are given separately for each agronomic aspect of crop management (see Tables 4, 5, 6, 7, 8, and 9); where appropriate, the figures include product, machinery and labor costs. Additional costs are production costs for the GM crop in comparison to the non-GM crop. Additional revenues are due to increased yield; they occur only in maize for grains and in organic potato. All values are given in CHF per hectare

${ }^{a}$ Control of the corn borer (material and labor) costs $176 \mathrm{CHF} /$ ha on non-GM maize. Because $20 \%$ of the surface of GM maize is non-Bt maize, the cost savings for GM maize are only $141 \mathrm{CHF} / \mathrm{ha}$

${ }^{\mathrm{b}}$ Negative additional costs represent cost savings

of silage (lower labor and machinery costs). Because a $4 \%$ yield increase was assumed for GM maize for grains (but not for maize for silage), the net margin of GM maize was considerably higher than that for non-GM maize (+270 CHF/ha).
Wheat The absolute net margins differed greatly between farming systems and were highest for organic and lowest for conventional wheat. In the integrated and conventional model system, the net margins for GM and non-GM wheat differed very little ( $-79 \mathrm{CHF} /$ ha for GM wheat). 
Table 15 Profitability of individual non-GM and GM crops

\begin{tabular}{|c|c|c|c|c|c|c|c|}
\hline \multirow[b]{2}{*}{ Crop } & \multirow{2}{*}{$\begin{array}{l}\text { Production system } \\
\text { Revenues and costs }\end{array}$} & \multicolumn{2}{|l|}{ Organic } & \multicolumn{2}{|l|}{ Integrated } & \multicolumn{2}{|l|}{ Conventional } \\
\hline & & Non-GM crop & GM crop & Non-GM crop & GM crop & Non-GM crop & GM crop \\
\hline \multirow[t]{4}{*}{ Maize (silage) } & Yield & 7,250 & 7,250 & 3,448 & 3,448 & 3,448 & 3,448 \\
\hline & Direct payments & 2,460 & 2,460 & 1,660 & 1,660 & 0 & 0 \\
\hline & Production costs & $-8,126$ & $-8,114$ & $-4,296$ & $-4,185$ & $-4,296$ & $-4,185$ \\
\hline & Net margin & 1,584 & $1,596(+12)$ & 812 & $923(+111)$ & -848 & $-737(+111)$ \\
\hline \multirow[t]{4}{*}{ Maize (grains) } & Yield & - & - & - & - & 3,460 & 3,606 \\
\hline & Direct payments & & & & & 0 & 0 \\
\hline & Production costs & & & & & $-2,714$ & $-2,598$ \\
\hline & Net margin & & & & & 746 & $1,008(+262)$ \\
\hline \multirow[t]{4}{*}{ Wheat } & Yield & 5,200 & - & 3,060 & 3,060 & 3,060 & 3,060 \\
\hline & Direct payments & 2,860 & & 1,660 & 1,660 & 0 & 0 \\
\hline & Production costs & $-1,999$ & & $-2,464$ & $-2,543$ & $-2,464$ & $-2,543$ \\
\hline & Net margin & 6,061 & & 2,256 & $2,177(-79)$ & 596 & $517(-79)$ \\
\hline \multirow[t]{4}{*}{ Potato } & Yield & 16,625 & 20,900 & 16,200 & 16,200 & - & - \\
\hline & Direct payments & 2,460 & 2,460 & 1,660 & 1,660 & & \\
\hline & Production costs & $-15,758$ & $-16,547$ & $-14,257$ & $-14,531$ & & \\
\hline & Net margin & 3,327 & $6,813(+3,486)$ & 3,603 & $3,329(-274)$ & & \\
\hline \multirow[t]{4}{*}{ Sugar beet } & Yield & - & - & - & - & 6,157 & 6,157 \\
\hline & Direct payments & & & & & 0 & 0 \\
\hline & Production costs & & & & & $-5,885$ & $-5,852$ \\
\hline & Net margin & & & & & 272 & $305(+33)$ \\
\hline \multirow[t]{4}{*}{ Soybeans } & Yield & 5,200 & - & - & - & - & - \\
\hline & Direct payments & 2,460 & & & & & \\
\hline & Production costs & $-2,659$ & & & & & \\
\hline & Net margin & 5,001 & & & & & \\
\hline \multirow[t]{4}{*}{ Grass/clover } & Yield & 3,626 & - & - & - & - & - \\
\hline & Direct payments & 1,240 & & & & & \\
\hline & Production costs & $-3,411$ & & & & & \\
\hline & Net margin & 1,455 & & & & & \\
\hline \multirow[t]{4}{*}{ Catch crop } & Yield & - & - & 718 & - & 718 & - \\
\hline & Direct payments & & & 0 & & 0 & \\
\hline & Production costs & & & $-1,148$ & & $-1,148$ & \\
\hline & Net margin & & & -430 & & -430 & \\
\hline \multirow[t]{4}{*}{ Green manure } & Yield & - & - & 0 & - & 0 & - \\
\hline & Direct payments & & & 0 & & 0 & \\
\hline & Production costs & & & -577 & & -577 & \\
\hline & Net margin & & & -577 & & -577 & \\
\hline
\end{tabular}

Net margins were calculated as yield+direct payments - production costs (including labor costs); for details, see text. The difference in net margin between the GM and the non-GM scenario is given in brackets. All values are given in CHF per hectare

Potato In the integrated model system, yields were unchanged, while production costs were higher for GM potato. Therefore, the net margin for GM potato was lower than that for non-GM potato $(-274 \mathrm{CHF} / \mathrm{ha}$ for GM potato). In the organic system, the increase in production costs was similar, but there was also a great increase in yield, due mainly to an increased proportion of marketable yield. On the whole, the net margin for GM potato was much higher than that for non-GM potato $(+3,486 \mathrm{CHF} /$ ha for $\mathrm{GM}$ potato).

Sugar beet The net margins for conventional production of GM and non-GM sugar beet differed very little $(+34 \mathrm{CHF} / \mathrm{ha}$ for GM sugar beet). 
Soy, grass/clover, catch crop, and green manure For these crops, no GM varieties were assumed. They were included in this study in order to assess crop rotations typical for Swiss agriculture.

\subsubsection{Production costs based on different assumptions (sensitivity analyses)}

Costs for GM seeds For the economic assessments, a "technology fee" of $30 \%$ on top of the conventional seed price was assumed for all GM crops. To test the robustness of our results, prices for GM seeds were also calculated with a "technology fee" of 24 and of $36 \%$ (see Table 16). In maize, wheat, and sugar beet, different assumptions for GM seed costs influence production costs only very little (less than $\pm 30 \mathrm{CHF} / \mathrm{ha}$ ). In potato, different assumptions for GM seed costs have a modest influence on production costs (less than $\pm 250 \mathrm{CHF} / \mathrm{ha}$ ).

Spread of a bivoltine race of the corn borer A univoltine race of the European corn borer is currently present in most regions of Switzerland (Derron et al. 2009). A single release of Trichogramma per annum is sufficient to control it. If a bivoltine race of the corn borer were to spread over a wide area in the future, appropriate control strategies would be (1) a second release of Trichogramma or (2) application of insecticides (e.g., indoxacarb in integrated/conventional farming, spinosad in organic farming) rather than the release of Trichogramma. To reflect the current distribution of corn borer races, the model rotations assumed a univoltine race, while the bivoltine race was included in the sensitivity analyses. Costs for controlling the corn borer for these variants are shown in Table 17. If a possible bivoltine race of the corn borer were controlled by means of a second release of Trichogramma, production costs would increase by $176 \mathrm{CHF} / \mathrm{ha}$ in all production systems. If it was controlled with insecticides instead of Trichogramma, production costs would slightly decrease in the integrated system and slightly increase in the organic system. In conclusion, the spread of a bivoltine race of the corn borer would have only a moderate influence on net margins (less than $200 \mathrm{CHF} / \mathrm{ha}$ ).

Traditionally bred, late blight-resistant potato varieties The model assumptions for non-GM potatoes were based on the late blight susceptibility of the most frequently used potato varieties (e.g., Agria). However, there are also late blightresistant non-GM varieties (e.g., Naturella). The model assumed that a moderately blight susceptible non-GM variety (e.g., Agria) would be replaced by a blight-resistant GM variety. We also calculated net margins for a scenario where a blight-resistant non-GM variety (e.g., Naturella) was replaced by a blight-resistant GM variety (Table 18). The net margin for GM potato differed from the variant non-GM potato because (1) it has a price premium on seeds and (2) it requires no control of the potato beetle. In both systems, the late blightresistant, non-GM potato had the highest net margin.

\subsubsection{Profitability of the model rotations}

In a final step, the net margins of each crop were averaged over the duration of the model rotations (see Table 19). In the non-GM scenarios, the organic model rotations had the highest average annual net margins, followed by the integrated model rotation. Due to the lack of direct payments, the conventional model rotations had much lower net margins. Due to the system boundaries, costs for co-existence were not included in the analysis. Thus benefits due to GM crops must at least compensate for co-existence costs in order to reach equal or better profitability.

Rotation no 1 In the organic model rotation no 1 , the average net margin was much higher for the GM scenario than for the non-GM scenario ( $+500 \mathrm{CHF} / \mathrm{ha})$. This increase was due almost exclusively to the increase for GM potato (almost $+3,500 \mathrm{CHF} / \mathrm{ha}$ ), which was averaged over the duration of the rotation ( 7 years).

Table 16 Costs for GM seeds based on different assumptions for price premiums

\begin{tabular}{llcrrr}
\hline Crop & Production system & Model: $30 \%$ & Variant 1: 24\% & \multicolumn{2}{c}{ Variant 2: $36 \%$} \\
\hline GM maize (silage) & Organic & 129 & 103 & $(-26)$ & 155 \\
GM maize (silage) & Integrated, conventional & 90 & 72 & $(-18)$ & 108 \\
GM maize (grains) & Conventional & 82 & 66 & $(-16)$ & $(+26)$ \\
GM wheat & Integrated, conventional & 70 & 56 & $(-14)$ & $(+18)$ \\
GM potato & Organic & 1,175 & 940 & $(-235)$ & 1,410 \\
GM potato & Integrated & 929 & 743 & $(-186)$ & $(-235)$ \\
GM sugar beet & Conventional & 143 & 114 & $(-29)$ & $(-186)$ \\
\hline
\end{tabular}

In the model for costs of GM seeds, a price premium of $30 \%$ on top of the price for non-GM seeds was assumed (see production costs, Table 14). In the sensitivity analyses, alternative price premiums of $24 \%$ (=variant 1$)$ or $36 \%$ (=variant 2 ) were assumed. The difference between each variant and the model is given in brackets. All values are given in CHF per hectare 
Table 17 Costs for the control of the corn borer based on different assumptions

\begin{tabular}{llcccc}
\hline Crop & Production system & $\begin{array}{c}\text { Model: univoltine race } \\
1 \times \text { Trichogramma }\end{array}$ & $\begin{array}{c}\text { Variant 1: bivoltine race } \\
2 \times \text { Trichogramma }\end{array}$ & $\begin{array}{c}\text { Variant 2: bivoltine race } \\
1 \times \text { insecticide }\end{array}$ \\
\hline Non-GM maize (silage) & Organic & 176 & 352 & $(+176)$ & 196 \\
Non-GM maize (silage) & Integrated, conventional & 176 & 352 & $(+176)$ & 138 \\
Non-GM maize (grains) & Conventional & 176 & 352 & $(+176)$ & 138 \\
\hline
\end{tabular}

Costs were calculated for the model assumptions (univoltine race) and for two possible control strategies for the bivoltine race: a second release of Trichogramma (=variant 1) or application of insecticides instead of the release of Trichogramma (=variant 2). The calculations refer only to nonGM maize; in GM maize, the spread of a bivoltine race has no impact because the Bt trait controls the corn borer. The difference between each of these variants and the model assumption is given in brackets. All values are given in CHF per hectare

Rotations no 2-5 In the model rotations no 2-5, the average net margin for the non-GM, and the GM scenario differed little (less than $\pm 100 \mathrm{CHF} / \mathrm{ha}$ ).

Rotation no 6 In the model rotation no 6 , the average net margin for the GM scenario was considerably higher than for the non-GM scenario (less than $\pm 261 \mathrm{CHF} / \mathrm{ha}$ ). In absolute figures, however, the net margin was also low in the GM scenario and was not competitive with the integrated model rotation.

In conclusion, most rotations that include GM crops provide only marginally improved profitability, as compared to the non-GM scenarios under the model conditions.

\subsection{Nonmonetary impacts of GM arable crops}

Management flexibility Under our model conditions, the management of GM crops allowed more flexibility than the management of non-GM crops. This applies specifically to the management of weeds, pests, and diseases. It reduced labor peaks and allowed for the management of larger surfaces and for part-time farming. In the literature, simplicity and flexibility of the weed control program have been identified as primary reasons why farmers switch to HT soy (Carpenter and Gianessi 1999).

Varietal choice Registration of GM crops is costly and time consuming, and can only be done by large companies

Table 18 Net margins for non-GM potatoes with different late blight susceptibility and for GM potato

\begin{tabular}{lccc}
\hline $\begin{array}{l}\text { Production } \\
\text { system }\end{array}$ & $\begin{array}{l}\text { Model non-GM } \\
\text { potato: moderately } \\
\text { susceptible }\end{array}$ & $\begin{array}{l}\text { Variant non-GM } \\
\text { potato: resistant }\end{array}$ & $\begin{array}{l}\text { Model GM } \\
\text { potato: resistant }\end{array}$ \\
\hline organic & 3327 & 7724 & 6813 \\
integrated & 3603 & 4147 & 3329 \\
\hline
\end{tabular}

The model assumed that the non-GM potato was moderately susceptible (e.g., variety "Agria"), while the variant assumed that it was resistant (e.g., variety "Naturella"). All values are given in CHF per hectare focusing on global markets. Varieties of arable crops are currently available that are well adapted to the local conditions prevailing in different regions of Switzerland. The experts doubt whether GM crops would be equally adapted to local conditions.

Dispersal of GM pollen into honey With some GM crops (particularly maize and oil seed rape), it is impossible to avoid GM pollen being collected by bees and thus being detectable in honey. Whether or not this would constitute a problem for Swiss beekeepers was not assessed (see system boundaries) but would depend in part on the general attitude of consumers towards GMOs.

\subsection{Economic calculations for GM apples and model orchards}

All economic calculations were based on the horticultural simulation models "Arbokost" and "Arbokost-Bio 2006" (Bravin et al. 2010). Arbokost models the entire lifetime of an orchard, differentiating between build-up and full yield years. The model simulates the cash flow for each year (profit plus allowance for depreciation). Total revenues reflect yield $x$ market price plus direct payments. The total production costs take account of direct costs (fertilization, pest management, insurance payments, tree removal, and other costs such as certification etc., paid and family farm labor, machinery, buildings, orchard investment including interest, land) and structural costs (costs of buildings, machinery, labor, and interest which cannot be allocated to a specific activity). Total cash flow, as calculated by the Arbokost model, was discounted to calculate annual cash flow. Finally, the annual cash flow was calculated for entire model orchards, using the percentages of trait combinations given in Table 11 .

Calculations were made according to the detailed specifications elaborated in the agronomy workshops (see "agronomic assumptions for the model horticultural farms"). The model considers the following variables:

- variable resistance to scab, with consequences for plant protection measures and for marketable yield 
Table 19 Average annual net margins for non-GM and GM rotations Model rotation Farming system Non-GM rotation GM rotation

\begin{tabular}{llrrl}
\hline No 1 & Organic & 3,423 & 3,923 & $(+500)$ \\
No 2 & Organic & 2,639 & 2,642 & $(+3)$ \\
No 3 & Integrated & 2,017 & 1,936 & $(-81)$ \\
No 4 & Conventional & -510 & -463 & $(+47)$ \\
No 5 & Conventional & 494 & 453 & $(-41)$ \\
No 6 & Conventional & 754 & 1,015 & $(+261)$ \\
\hline
\end{tabular}

Average annual net margins are calculated as the sum of the net margins for each crop in the rotation (plus catch crops and green manure), divided by the number of years. For details, see text. All values in CHF per hectare. Rotations are described in Table 1

- variable resistance to fire blight, with consequences for plant protection measures, sanitation pruning, and removal of trees

\subsubsection{Parameter settings}

In general, the default parameter settings in Arbokost were used. Only a few parameters (those that depend on scab or fire blight) were varied for susceptible and resistant varieties. These are (1) the number and kind of sprays used against scab and fire blight (see Tables 12 and 13), (2) marketable yield in relation to scab susceptibility (see below), and (3) tree health in relation to fire blight susceptibility (see below).

Marketable yield in relation to scab The model assumed two quality classes for organic and three for integrated apples. A certain proportion of apples cannot be marketed as class I for various reasons (e.g., size, color, blemishes); this proportion was constant across all scenarios. In addition, scab infection may lead to a variable degree of de-classification (Table 20). In the organic model orchard, $75 \%$ of the susceptible apples were assumed to be marketed as Tafelobst (dessert fruit) in years with low disease pressure but only $50 \%$ in years with high disease pressure; the weighted average for all years was used to calculate revenues. A typical scab control program with efficient, synthetic fungicides was assumed for integrated production, and scab losses were assumed to be minimal in difficult years also. The Arbokost default settings were used for prices in the different quality classes.

Tree health in relation to fire blight In Switzerland, fire blight is a new disease (first observed in 1989) and is still spreading (Schärer 2000; Holliger 2009). The ultimate level of disease pressure is difficult to predict but has been estimated on the basis of experience in southern Germany. Here, we discriminated between "slight" and "severe" infections. An infection was designated as "slight" if it could be cured by sanitation pruning and as "severe" if the trees had to be removed. The frequency of healthy, slightly infected, and severely infected trees is shown in Table 21.

Costs for sanitation pruning The labor requirement for sanitation pruning of an entire orchard was estimated at $500 \mathrm{~h}$ per hectare. Thus, pruning $4 \%$ of the trees would require $20 \mathrm{~h} / \mathrm{ha}$.

Costs for tree removal The value of trees was estimated on the basis of Richtwerte für die Entschädigung von Kernobstanlagen bei Enteignung oder vorzeitiger Rodung wegen Schadenfall (Standard compensation levels for pome fruit orchards in cases of dispossession or early removal due to damage) (Bravin et al. 2009). The values were interpolated for a figure of 2,200 trees and corrected by a factor of 1.39 for the difference in the underlying returns and the returns on organic production systems in the simulation model. The average cost

Table 20 Proportion of apples in different quality classes

\begin{tabular}{|c|c|c|c|c|}
\hline Production system and scab trait & Disease pressure $^{\mathrm{a}}$ & Class I $(\%)$ & Class II (\%) & Class III $(\%)$ \\
\hline \multirow[t]{3}{*}{ Organic orchard, scab susceptible } & Low & 75 & - & 25 \\
\hline & High & 50 & - & 50 \\
\hline & Weighted average & 68.8 & - & 31.2 \\
\hline Organic orchard, scab resistant & All years & 75 & - & 25 \\
\hline \multirow[t]{3}{*}{ Integrated orchard, scab susceptible } & Low & 65 & 25 & 10 \\
\hline & High & 62 & 24 & 14 \\
\hline & Weighted average & 64.4 & 24.8 & 10.8 \\
\hline Integrated orchard, scab resistant & All years & 65 & 25 & 10 \\
\hline
\end{tabular}

Proportions of apples in different quality classes. In organic apples, the quality class Tafelobst (dessert fruit) corresponds to the classes I and II of integrated apples, while Mostobst (fruit for processing) corresponds to class III. In scab-susceptible varieties, the proportion of quality classes depended on disease pressure. In resistant varieties, proportions were identical for years with low and high disease pressure. The weighted average for all years was used in the economic assessments

${ }^{\text {a }}$ Disease pressure is assumed to be low in 4 out of 5 years and high in 1 out of 5 years. In the economic assessments, the weighted average for all years is used 
Table 21 Tree health in relation to fire blight

\begin{tabular}{|c|c|c|c|c|}
\hline Production system and fire blight trait & Disease pressure $^{\mathrm{a}}$ & Healthy $(\%)$ & Slight infection $(\%)$ & Severe infection $(\%)$ \\
\hline \multirow[t]{3}{*}{ Organic orchard, fire blight-susceptible } & Low & 100 & 0 & 0 \\
\hline & High & 50 & 10 & 40 \\
\hline & Weighted average & 90 & 2 & 8 \\
\hline \multirow[t]{3}{*}{ Organic orchard, fire blight-resistant } & Low & 100 & 0 & 0 \\
\hline & High & 50 & 40 & 10 \\
\hline & Weighted average & 90 & 8 & 2 \\
\hline \multirow[t]{3}{*}{ Integrated orchard, fire blight-susceptible } & Low & 100 & 0 & 0 \\
\hline & High & 80 & 20 & 0 \\
\hline & Weighted average & 96 & 4 & 0 \\
\hline Integrated orchard, fire blight-resistant & All years & 100 & 0 & 0 \\
\hline
\end{tabular}

Proportions of healthy, slightly infected and severely infected apple trees (for explanations, see text)

${ }^{a}$ Disease pressure is assumed to be low in 4 out of 5 years and high in 1 out of 5 years. In the economic assessments, the weighted average for all years is used

${ }^{\mathrm{b}}$ In resistant varieties grown in the integrated orchard, proportions are identical for years with low and high disease pressure

for tree removal (reduced estimated useful life of the trees plus removal costs) amounted to $78,647 \mathrm{CHF} /$ ha for the entire orchard $(100 \%$ of the trees).

\subsubsection{Production costs for different ideotypes of apple varieties}

The different kinds of production costs are shown in Table 22 . Labor is the most significant position but is relatively constant across all resistance traits. Tree removal occurs only in cases of severe fire blight infection. These costs are responsible for most of the variability between resistance traits. The production costs (per kilogram apples) in the organic system are generally much higher than those in the integrated system. This is due to (1) higher machinery costs, mainly for thinning, (2) higher depreciation for the orchard due to higher planting material costs, (3) lower yield, and (4) high costs for tree removal. While scab resistance alone does not lead to great savings in production costs $(-4 \%)$, fire blight resistance reduces total production costs by $12-15 \%$ compared with the susceptible baseline.

\subsubsection{Returns for different ideotypes of apple varieties}

The returns are shown in Table 23. Yield in class I made the major contribution to the total revenues. Yield in other quality classes and direct payments made a minor contribution.

\subsubsection{Profitability of different ideotypes of apple varieties}

Profitability was calculated as returns minus costs. Profits are shown in Table 24. Taking total production costs into account (direct costs, fixed costs, labor costs for hired labor and family farm labor), the calculated profit of an average full-yield year was always negative. In order to achieve a positive economic performance, the farm family could accept to work for less than the assumed wages (farm

Table 22 Relevant production costs for an average full-yield year for different apple ideotypes and production systems

\begin{tabular}{|c|c|c|c|c|c|c|c|}
\hline \multicolumn{2}{|c|}{ Resistance trait ideotype } & Labor & Capital & Machinery & Tree removal $^{\mathrm{a}}$ & Other costs & Total costs \\
\hline \multicolumn{8}{|c|}{ Organic model orchard } \\
\hline ss & Scab susceptible and fire blight susceptible & 22,723 & 2,912 & 6,992 & 6,292 & 11,336 & 50,285 \\
\hline rs & Scab resistant and fire blight susceptible & 22,015 & 2,779 & 6,022 & 6,292 & 10,475 & 47,583 \\
\hline $\mathrm{sr}$ & Scab susceptible and fire blight resistant & 21,956 & 2,478 & 6,654 & 0 & 9,234 & 40,322 \\
\hline $\mathrm{rr}$ & Scab resistant and fire blight resistant & 20,907 & 2,342 & 5,224 & 0 & 8,278 & 36,751 \\
\hline \multicolumn{8}{|c|}{ Integrated model orchard } \\
\hline ss & Scab susceptible and fire blight susceptible & 23,019 & 2,289 & 4,754 & 0 & 7,642 & 37,704 \\
\hline rs & Scab resistant and fire blight susceptible & 22,842 & 2,249 & 4,482 & 0 & 7,301 & 36,875 \\
\hline $\mathrm{rr}$ & Scab resistant and fire blight resistant & 21,485 & 2,088 & 4,110 & 0 & 6,681 & 34,365 \\
\hline
\end{tabular}

All values in CHF per hectare; calculation using ARBOKOST

${ }^{\mathrm{a}}$ Tree removal in case of severe fire blight infection 
Table 23 Relevant returns for an average full-yield year for different apple ideotypes and production systems

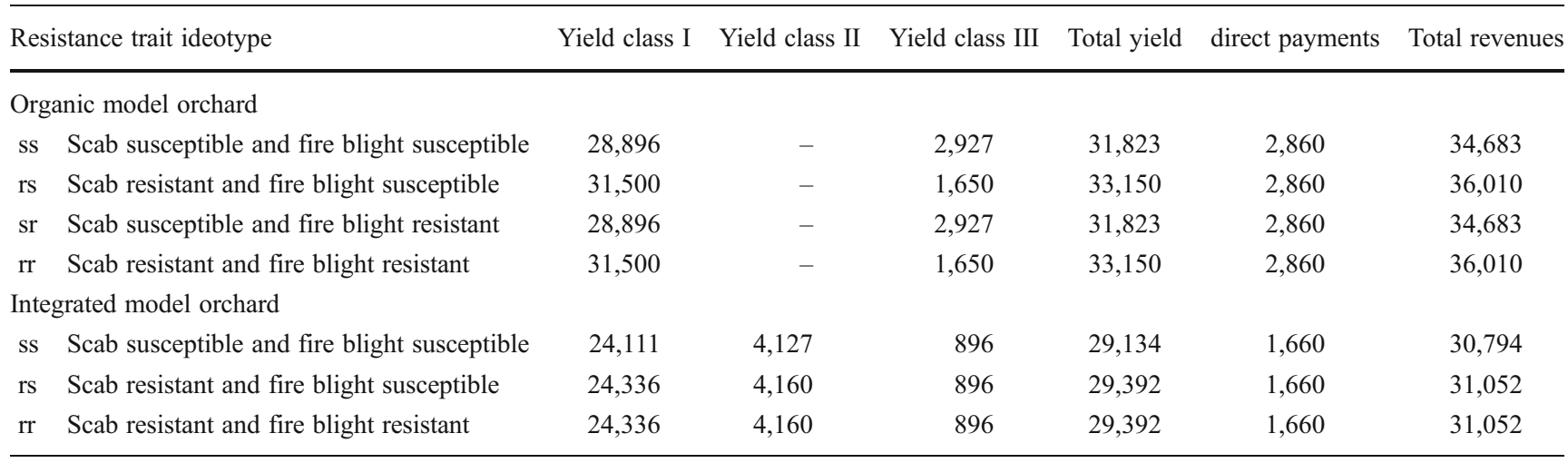

All values in CHF per hectare; calculation with ARBOKOST

manager, $35 \mathrm{CHF} / \mathrm{ha}$; farm family, $24 \mathrm{CHF} / \mathrm{h})$. Otherwise, the farm would not be able to compensate for the depreciation and therefore would not remain economically viable.

\subsubsection{Benefits of single-resistance traits}

Cost savings for the trait of scab resistance were calculated from the relevant production costs for a susceptible variety minus those for a resistant variety (see Table 22), and likewise for fire blight. Additional revenues were calculated from the relevant returns on a resistant variety minus those on a susceptible variety (see Table 23).

Disease resistance had multiple effects on profitability (see Table 25). Resistant varieties needed fewer pesticide sprays, which reduced the costs for labor, machinery, and plant protection products. In addition, scab resistance increased the proportion of apples in class I, which lead to additional revenues. In the organic model orchard, fire blight resistance eliminated the need for tree removal, thus leading to considerable cost savings. The effects of both resistance traits were highly context sensitive. They varied

Table 24 Profits for different trait combinations for an average fullyield year for different apple ideotypes and production systems

\begin{tabular}{lll}
\hline \multicolumn{2}{l}{ Resistance trait ideotype } & Profit \\
\hline \multicolumn{2}{l}{ Organic } & model orchard \\
ss & Scab susceptible and fire blight susceptible & $-15,602$ \\
rs & Scab resistant and fire blight susceptible & $-11,573$ \\
sr & Scab susceptible and fire blight resistant & $-5,639$ \\
rr & Scab resistant and fire blight resistant & -741 \\
Integrated & model orchard & \\
ss & Scab susceptible and fire blight susceptible & $-6,910$ \\
rs & Scab resistant and fire blight susceptible & $-5,823$ \\
rr & Scab resistant and fire blight resistant & $-3,313$ \\
\hline
\end{tabular}

All values in CHF per hectare. Profits were calculated as returns (see Table 23) minus costs (see Table 22) greatly for the organic and the integrated model orchard. There was also an interaction between the two resistance traits in the organic system. Whether such an interaction would also occur in the integrated system cannot be determined because one of the possible trait combinations was not assumed for the integrated model orchard.

\subsubsection{Profitability of the model orchards in different scenarios}

Model orchard profitability (see Table 26) was calculated from the profit obtained with each variety multiplied by its proportion in the model orchard in the respective scenario (see Table 11). The profitability of individual varieties depends on their resistance traits in this model (see Table 24).

In the organic model orchard, the profit in GM scenario 1 was lower than in the baseline scenario. This was due to the loss of the varieties Ariwa and Boskoop (both classified as fire blight resistant). Changes in varietal composition are the consequence of both agronomic and market considerations and are discussed in the section on agronomic assumptions. Transition from GM scenario 1 to 2 had a much greater effect than transition from the baseline to GM scenario 1 .

In the integrated model orchard, transition from GM scenario 1 to 2 also had a greater effect than transition from the baseline to GM scenario 1, but the effect was less pronounced than in the organic model orchard.

In conclusion, GM apples with resistance to scab and fire blight provide substantial economic benefits in both integrated and organic farming systems. The economic benefit depends directly on the availability of efficient plant protection products and/or traditionally bred varieties with resistance traits.

\subsection{Nonmonetary impacts of GM apples}

Management flexibility and emergency measures Spraying for scab control is a predictable activity for apple growers, 
Table 25 Estimates of profitability for single resistance traits, calculated from cost savings and additional returns

All values in CHF per hectare

\begin{tabular}{lccc}
\hline Production system, other resistances & Cost savings & Additional revenues & Total benefit \\
\hline Effects of scab resistance & & & \\
Organic orchard, fire blight susceptible & $-2,702$ & 1,327 & 4,029 \\
Organic orchard, fire blight resistant & $-3,571$ & 1,327 & 4,898 \\
Integrated orchard, fire blight susceptible & -829 & 258 & 1,087 \\
Effects of fire blight resistance & & 0 & 9,963 \\
Organic orchard, scab susceptible & $-9,963$ & 0 & 10,832 \\
Organic orchard, scab resistant & $-10,832$ & 0 & 2,510 \\
Integrated orchard, scab resistant & $-2,510$ & & \\
\hline
\end{tabular}

although exact spraying times need to be adjusted to weather conditions. Thus, scab-resistant apple varieties improved management flexibility only to a small extent. By contrast, the occurrence of fire blight is unpredictable and imposes a sudden, considerable workload for sanitation pruning and/or tree removal. Fire blight-resistant varieties thus reduce the need for such emergency measures. In addition, fire blight can pose an existential threat to apple growers and may therefore cause emotional stress. This is particularly true for organic growers, who have no fully effective control measures at their disposal.

Tolerance for host plants of fire blight Meadow trees and some species of wild plants are alternative hosts of fire blight. The current recommendation is that alternative hosts should not be planted within $500 \mathrm{~m}$ of commercial apple orchards (Landwirtschaftliches Zentrum SG 2006). The widespread adoption of fire blight-resistant apple varieties would ease the pressure to clear alternative host plants and help preserve meadow trees.

Varietal choice Registration of GM crops is costly and time consuming, and can only be done by large companies focusing on global markets. Under these conditions, it is likely that only the most widely planted GM apple varieties would be commercialized.

Dispersal of GM pollen and antibiotics into honey With the cultivation of GM apples, it is impossible to avoid GM

Table 26 Profitability of the model orchards under different scenarios

\begin{tabular}{llll}
\hline & \multicolumn{3}{l}{ Scenario } \\
\cline { 2 - 4 } Resistance traits & Baseline & GM 1 & GM 2 \\
\hline Organic model orchard & $-10,408$ & $-10,920$ & $-1,280$ \\
Integrated model orchard & $-6,910$ & $-6,062$ & $-4,104$ \\
\hline
\end{tabular}

Model orchard profitability was calculated from the profit of each trait combination (Table 24) multiplied by its frequency under the respective scenario (Table 11). All values in CHF per hectare

Baseline baseline scenario, GM 1 GM scenario 1, GM 2 GM scenario 2 pollen being collected by bees and thus being detectable in honey. Whether or not this would constitute a problem for Swiss beekeepers would depend in part on the general attitude of consumers towards GMOs (as in arable crops) but was not assessed (see system boundaries). Under the model conditions for the integrated orchard, there is a risk of streptomycine residues in the fire blight-susceptible varieties and of GM pollen in the fire blight-resistant varieties.

\section{Agro-ecological impact assessment for the cultivation of GM crops}

\subsection{Establishment and outcrossing of GM crops in Switzerland}

One of the major concerns regarding GM crops is that they might establish permanent populations and/or pass transgenes to non-GM fields of the same crop and/or pass transgenes to related wild species by outcrossing (Chapman and Burke 2006). These risks vary greatly for different crops and are therefore discussed separately for each model crop. The following aspects are considered here:

- Can the GM crop establish wild populations in Switzerland?

- Can the GM crop outcross with non-GM crops of the same species?

- Can the GM crop outcross with related wild species?

Here, the risks of establishment and outcrossing are discussed in the context of proper use of registered GM crops. Incidents involving human error present additional risks. Recent examples of human error include the accidental commingling of GM with non-GM seeds, the accidental release of unapproved transgenes into commercial seed, and the failure of the industry and growers to follow trial protocols (Marvier and Van Acker 2005).

The potential for pollen dispersal and outcrossing of various GM crops under Swiss conditions is described in Sanvido et al. (2005) and Bigler et al. (2008). The potential 
for overwintering in the Swiss lowland is described in Bigler et al. (2008). Where no other references are given, the statements in this section are based on these two studies.

Maize Individual maize plants can hibernate, but no populations establish in Switzerland. Outcrossing with other maize fields, including those for seed production, is frequent. For details on pollen flow in maize, see Feil and Schmid (2001). Maize has no wild relatives in Switzerland.

Wheat Seeds do not survive winter in the seed bank, but summer and winter wheat can survive winter as seedlings. Thus, individual wheat plants hibernate and small populations establish in Switzerland. Outcrossing with other wheat plants is rare. Outcrossing with the wild relative Aegylops cylindrica (which is present in Switzerland) is possible and the offspring are fertile at least to a certain extent (Guadagnuolo et al. 2001; Econopouly et al. 2011). Outcrossing between wheat and $A$. cylindrica has been observed in Idaho (Hanson et al. 2005) and Colorado (Gaines et al. 2008; Econopouly et al. 2011). Whether or not Aegylops can outcross with native wild grasses in Switzerland ("bridging") requires verification. For details on pollen flow in wheat, see Feil and Schmid (2001).

Oilseed rape Rape plants hibernate and populations establish regularly in Switzerland. Rape establishes as volunteers in fields, field margins, and elsewhere in the landscape. Volunteers flower throughout the year. Seeds persist in the seed bank for several years, with evidence of persistence up to 10 years (Lutman 2003; Gruber et al. 2004). Long-distance dispersal of rape seeds occurs when harvesters are not cleaned properly or when seeds are lost during transport (Lutman 2003). Pollen is transported by bees and by the wind. Outcrossing of GM rape with other rape plants is frequent. Outcrossing occurs with other Brassica species (cultivated and wild, including green manures). Simulations show that outcrossing cannot be prevented in rape, even with large buffer zones (Menzel et al. 2005). For further modeling studies, see Ceddia et al. (2007) and Colbach (2009). The outcrossing of GM rape in Canada is described in Marvier and Van Acker (2005). The experts present at the workshop on agro-ecology concluded that authorization of GM rape was unlikely in Switzerland because of its outcrossing potential. For this reason, no model rotations containing GM rape were included in this paper.

Potato No wild populations of potato are established in Switzerland. Potato tubers may hibernate and form volunteer plants in the year after a potato crop, while seeds rarely germinate and not all varieties produce seeds at all. Seeds are viable for at least 7 years (see Lutman 2003). Loss of tubers during transport may result in some limited long-distance dispersal. Outcrossing with other potato plants was considered to be insignificant. Potato has no wild relatives in Switzerland.
Sugar beet Sugar beet plants hibernate and/or regenerate from tuber chips, and populations establish. Early bolting individuals produce seeds which remain viable for a long period. Loss of tubers or tuber chips during transport may result in some limited long-distance dispersal. Outcrossing occurs with other beets (cultivated and volunteer beets, cultivated relatives; Bartsch et al. 1999). Sugar beet has no wild relatives in Switzerland, though it does in northern Italy (Bartsch and Schmidt 1997).

Apple Apple seeds may be carried from the orchard to hedges, where they can develop into apple trees. In GM cultivars, the resistance to scab and fire blight might give such trees a small selective advantage over wild (Malus sylvestris) or volunteer apple trees, but not over other trees and shrubs also present in the hedge. In apples, most pollination takes place within the orchard, but pollen is also carried much further (Reim 2008). Outcrossing occurs with cultivated apples as well as with the native wild apple, M. sylvestris. Hybridization between cultivated and wild apples is very common (Reim 2009). If GM apples cross with a non-GM apple tree, the resulting apples will carry transgenes in the seeds (where they can be detected) but not in the flesh (the part of the fruit which is usually consumed). Due to the fact that the resistance genes in the model orchards come from the genus Malus, no genes from other genera enter the population.

\subsection{Environmental impact of HT arable crops}

The environmental impact of HT crops is driven mainly by the effects of altered weed management practices. Changes in weed management practices include the use of different herbicides (with a different spectrum of activity and different efficacy), different timings of applications, and the transition from tillage to no-till management. Altered weed management practices occur only in the integrated model farms. HT crops are not grown in organic systems because this trait has no value when herbicides cannot be used. Thus. the HT trait is irrelevant for the organic model farms.

\subsubsection{Impact of HT crops on herbicide use}

The cultivation of HT crops drastically changed the kinds of herbicides used and sometimes also the timing of their application in the scenarios (for details, see Tables 4, 5, and 7). Various active ingredients were replaced by either glyphosate or glufosinate. In most cases, the number of herbicide applications was not changed. The herbicides used in the non-GM scenarios were typical examples for each crop, which were explicitly listed in the "price catalogue" for agricultural inputs (Schoch 2009). Other herbicides with 
similar effects at similar costs but different ecotoxicological properties could have been used as well. Given this variability, no further ecotoxicological assessment of the herbicides used was attempted. In general, glyphosate and glufosinate are considered to be less environmentally damaging than the herbicides they replace (Duke and Cerdeira 2005a). However, this may not be true for every cropherbicide combination (Duke and Cerdeira 2005b) and if the same herbicide is applied continuously.

"Roundup", the original herbicide based on glyphosate, has been reported to be toxic to the tadpole stage of frogs (Relyea 2005; Relyea et al. 2005). A laboratory study has shown that the surfactant polyethoxylated tallowamine (POEA) contributes most, if not all, of the toxicity of the original Roundup formulation. Pure technical glyphosate was far less toxic and so were the newer glyphosate formulations lacking POEA (Howe et al. 2004). A recent review comes to the same conclusion regarding the toxicity of POEA to amphibians. However, there are conflicting opinions concerning the risks posed under field conditions (Mann et al. 2009). The economic calculations assumed that, during the study period, only the original Roundup would be registered for use on $\mathrm{HT}_{\text {gly }}$ crops. Thus there was a risk of toxicity to amphibians. The extent to which amphibians (and more specifically juveniles) would be exposed to glyphosate and/or POEA under Swiss agricultural conditions remained unclear. If negative impacts on amphibians were to be recorded, these could be mitigated by registering POEA-free formulations of glyphosate and withdrawing registration for formulations containing POEA.

There is some evidence that herbicides can cause endocrine disruption in aquatic organisms at much lower doses than toxic effects (Hayes et al. 2006a). Because of its widespread occurrence in water, endocrine disruption has been studied particularly for atrazine. Some studies have documented endocrine disruption in the laboratory (e.g., Hayes et al. 2006b), while a critical review concluded that most observations do not support such effects in fish, amphibians, and reptiles (Solomon et al. 2008). In addition, certain mixtures of different pesticides can have stronger effects than single pesticides tested on their own (e.g., Hayes et al. 2006a). Because endocrine disruption caused by pesticides is still debated among scientists, it was not taken into account in this study.

The application of glyphosate to soil results in a shortterm stimulation of microbial activity and functional diversity (after 15 days), most likely due to glyphosate acting as a source of $\mathrm{C}, \mathrm{N}$, and P. Thirty days after treatment, nontarget effects were observed, but these were inconsistent between different types of vegetation (Mijangos et al. 2009). While glyphosate is metabolized by some soil micro-organisms, it was found to be toxic to several bacteria and fungi (Yamada et al. 2009). In other studies, no meaningful differences in soil microbial community and/or nematode populations were detected between glyphosate and other herbicides (Liphadzi et al. 2005; Weaver et al. 2007).

The transport of pesticides into surface and groundwater (leaching) can be reduced with "good agricultural practices", which are a statutory pre-requisite for the use of pesticides in Switzerland. The set of measures includes buffer strips along water courses. Their effectiveness and practicability is reviewed in Reichenberger et al. (2007); it is never $100 \%$. The extent of pesticide transport from agricultural fields into water depends on the properties of the field as well as on rainfall patterns (Leu et al. 2004, 2005; Singer et al. 2005; Gomides et al. 2008). Inadequate cleaning of spraying equipment and inappropriate disposal of pesticide containers and leftovers provide additional "point sources" of pesticide contamination (Singer et al. 2005). In Switzerland, herbicide losses are generally below $1 \%$ (Leu et al. 2004) but may vary between 0.6 and $3.5 \%$ under extremely wet conditions (Leu et al. 2005). The risk of ground- and surface-water pollution from glyphosate is limited (Borggaard and Gimsing 2008) because it is more strongly bound to soil minerals than many other pesticides (Borggaard and Gimsing 2008). Nevertheless, glyphosate residues have been detected in Swiss and French surface waters (Botta et al. 2009; Hanke et al. 2010). In both studies, non-agricultural sources contributed significantly.

The "environmental impact quotient" (EIQ) was developed to quantify the environmental impacts of pesticide use. It takes into account the effects on farm workers, consumers, and ecology (fish, birds, honey bees, beneficial insects) and integrates the effects of herbicides, insecticides, and all other pesticides. High EIQ values indicate high environmental impact. Under US conditions, the EIQ declined in transgenic soybean, maize, and oilseed rape (Kleter et al. 2008). However, the authors point out that these findings cannot be applied directly to Europe due to differences in agricultural practices. At the global scale, GM crops reduced the quantities of pesticides used by $6 \%$, and the EIQ by $14 \%$ (Brookes and Barfoot 2005). In an analysis of soy grown in South America, glyphosate was the pesticide with the lowest product-specific EIQ value. However, as glyphosate has a very high application rate, it also has a high field EIQ and was the largest contributor to the total field EIQ. As a result, GM soy had a higher EIQ than non-GM soy (Bindraban et al. 2009).

In an 8-year field experiment in Germany, Hommel et al. (2006) compared the environmental risk potential associated with herbicide application in non-GM and glufosinatetolerant oilseed rape and maize. The indicator "frequency of application" (Behandlungsindex) increased from 0.9 in non-GM maize to 1.2 in $\mathrm{HT}_{\text {glu }}$ maize, but decreased from 1.3 in non-GM rape to 0.9 in $\mathrm{HT}_{\text {glu }}$ rape. In both crops, the "SYNOPS" risk potential was greatly reduced for GM crops (often $>95 \%$ ). 


\subsubsection{Impact of altered weed management on biodiversity}

HT crops made up a very high proportion of the integrated and conventional model rotations. The frequency of GM traits in the model rotations is shown in Table 27. The HT trait is absent from the organic model rotations but very frequent $(75-100 \%)$ in the integrated and conventional model rotations.

\subsubsection{Impact of altered weed management on biodiversity-flora}

The largest field study on the effects of altered weed management is a series of co-ordinated field trials in the UK called "Farm Scale Evaluation" (FSE). Because comparable data are not available from Central Europe, our discussion of the effects of weed management is based mainly on the FSE results from the UK. The FSE comprised a large number of beet, maize, and rape fields. Each field was split in two halves. One half was sown with a herbicide-tolerant GM crop and treated with the corresponding broadspectrum herbicide (glyphosate or glufosinate). The other half was sown with a non-GM cultivar of the same crop and treated with a herbicide in line with standard practice. Experimental details are given in the FSE studies cited below. In the FSE study, a clear reduction of the arable flora ("weeds") by HT crops was demonstrated (Heard et al. 2003). In HT sugar/fodder beet, weed biomass was six times lower than in non-GM beets, "seed rain" (precipitation of seeds onto the soil surface) was three times lower, and the seed bank in the following year was 1.2 times lower. In HT spring oilseed rape, weed biomass was three times lower, seed rain was five times lower, and the seed bank in the

Table 27 Frequency of GM traits in the model rotations

\begin{tabular}{|c|c|c|c|c|c|}
\hline \multirow{2}{*}{$\begin{array}{l}\text { Model } \\
\text { rotation }\end{array}$} & \multirow{2}{*}{$\begin{array}{l}\text { Farming } \\
\text { system }\end{array}$} & \multicolumn{4}{|c|}{ Crop years } \\
\hline & & Total & HT crops & Bt maize & $\begin{array}{l}\text { Other GM } \\
\text { crops }\end{array}$ \\
\hline No 1 & Organic & 7 & $0(0 \%)$ & $1(14 \%)$ & $1^{\mathrm{a}}(14 \%)$ \\
\hline No 2 & Organic & 4 & $0(0 \%)$ & $1(25 \%)$ & $0(0 \%)$ \\
\hline No 3 & Integrated & 4 & $3(75 \%)$ & $1(25 \%)$ & $1^{a}(25 \%)$ \\
\hline No 4 & Conventional & 3 & $3(100 \%)$ & $2(67 \%)$ & $0(0 \%)$ \\
\hline No 5 & Conventional & 3 & $3(100 \%)$ & $0(0 \%)$ & $1^{\mathrm{b}}(33 \%)$ \\
\hline No 6 & Conventional & 1 & $1(100 \%)$ & $1(100 \%)$ & $0(0 \%)$ \\
\hline
\end{tabular}

The total number of crop years and the number (and percentage) of crop years with HT crops, Bt maize, and other GM crops is shown for each model rotation. GM maize is shown under HT crops as well as under Bt maize because the agro-ecological impact assessment is conducted separately for these two traits

${ }^{a}$ FR-NR-Bt potato

${ }^{\mathrm{b}}$ VR sugar beet following year was 1.3 times lower (but not significantly different). In HT maize, weed biomass was 1.8 times higher and seed rain was 1.9 times higher (but not significantly different), unlike beets and rape. However, the authors state that the non-GM maize plots had been treated with atrazine, which was more effective than the broad-spectrum herbicide used in GM maize, thus reversing the pattern for maize. Meanwhile, however, atrazine has been phased out and is no longer available for maize growing in Switzerland or the UK (see discussion in Gibbons et al. (2006)). In the field margins, the same patterns were observed, but they were less pronounced than within fields (Roy et al. 2003).

The "BRIGHT" project (Botanical and Rotational Implications of Genetically modified Herbicide Tolerance) also studied the effects of altered weed management in herbicide-tolerant sugar beet and oilseed rape in the UK, but on a smaller scale. The assessments were limited to botanical and agronomic aspects (weed control, outcrossing, costs etc.). For details, see Sweet et al. (2004). The BRIGHT trials produced a range of results, varying with the herbicide (glyphosate, glufosinate), the type of weed (broad-leaved, grass) and the age of weeds (Sweet et al. 2004).

Danish demonstration trials studied the effects of altered weed management in herbicide-tolerant beets, with special emphasis on the timing of herbicide applications. For details, see Strandberg and Pedersen (2002). In the Danish demonstration trials, early application of glyphosate resulted in very few weed species, low density, and very low biomass. With later glyphosate applications (following label instructions), weeds were more abundant and diverse. When glyphosate applications were delayed, weeds were even more abundant. However, the authors report that no weed seeds were produced in any of the glyphosate treatments (Strandberg and Pedersen 2002).

\subsubsection{Impact of altered weed management on biodiversity-fauna}

In the FSE study, the impacts on arthropods varied for different taxonomic groups. Most taxa of epigeal and aerial arthropods had similar populations in non-GM and GM crops, with a few exceptions. Bees followed the pattern described above for weeds within crops, but differences were significant in only two cases. Visits of butterflies were usually more frequent in non-GM crops, with some exceptions for GM maize. Collembola were always more frequent in GM crops (Haughton et al. 2003). In carabids and spiders, increases and decreases were evenly balanced. In staphylinids, no significant differences were observed. Gastropods, particularly the pest slug Deroceras reticulatum were more frequent in GM crops in most cases, but the difference was significant in only two cases (Brooks et al. 2003). 
To estimate the impact on granivorous birds, the availability of weed seeds in the FSE fields was analyzed with respect to the diets of 17 farmland bird species (Gibbons et al. 2006). In most cases, HT crops reduced the availability of seeds. In HT sugar/fodder beet, the seed diet for all 17 bird species was reduced (significantly for 16 species). In HT spring oilseed rape, the diet for all 17 bird species was reduced (significantly for 16 species). In HT winter oilseed rape, the diet was reduced for 14 bird species (significantly for 10 species) and increased for three bird species (significantly for 1 species). In HT maize, the diet for all 17 bird species was increased (significantly for five species); the authors attribute the reversal of the pattern in maize to the use of atrazine in non-GM maize (see section on arable flora above). Gibbons et al. (2006) point out that relatively few birds actually forage for weed seeds in the growing crops, and that the most important consequence is probably the availability of seeds postharvest. In a field survey at the FSE sites, bird populations (particularly those in winter, i.e., postharvesting of the GM crops) followed the pattern described above for seed rain (Chamberlain et al. 2007): there were fewer birds on (previous) GM sugar beet fields than on non-GM sugar beet fields, while for maize the opposite was found, and in spring oilseed rape no differences were observed. In two studies modeling the potential impact of HT crops on birds, Butler et al. (2007) found that HT crops had no substantial effect on the "Farmland Bird Index" in Great Britain, while Watkinson et al. (2000) concluded that cropping of HT beet could affect populations of the skylark negatively. It is unclear whether the impact on birds would be similar under Swiss conditions.

\subsubsection{Impact of altered weed management on biodiversity - conclusions}

The experts concluded that frequent use of GM crops would reduce diversity of the arable flora, with secondary effects on the fauna. Continuous use of highly effective herbicides is likely to reduce weed populations, weed diversity, and weed seed banks over time, especially if these effects accumulate over the rotations. Reductions in biodiversity seem unavoidable for the arable flora and likely for herbivorous and nectar-feeding arthropods and for granivorous birds. The impact on other arthropods is more difficult to predict.

There is considerable flexibility for fine-tuning the time of herbicide application in HT crops. In the Danish demonstration trials, early application of glyphosate resulted in very few weeds, while delayed application resulted in more abundant weeds, without any negative impacts on yield (Strandberg and Pedersen 2002). In sugar beet, weed management consisting of an early band application followed by a late overall application of glyphosate resulted in elevated weed and arthropod populations without compromising yield (Dewar et al. 2003). Thus, weed management in HT crops could be fine-tuned in the future to optimize biodiversity with equal yields or to maximize yields (Dewar et al. 2003). It is difficult to predict in what ways and to what extent such fine-tuning might occur in the future. However, it was assumed here that such adaptations would not take place within the time frame covered in this study.

\subsubsection{Impact of altered weed management on the soil}

In the integrated and conventional model rotations, most GM crops were sown with direct drilling, while the non-GM crops were sown after minimum tillage. Direct drilling led to better soil cover and less soil disturbance than plow or minimum tillage, thus reducing the potential for erosion (see, e.g., Paustian 2005). Continuous direct drilling over the entire rotation was expected to improve soil structure and water infiltration (e.g., Paustian 2005). This would facilitate plant growth, reduce erosion and therefore contribute to soil fertility. As a result of continuous no-till management (rotation no 4), more micro-organisms and thus also more decomposer organisms were expected to be found in the uppermost layers of the soil, as this layer shows an increase in soil carbon and microbial activity (Paul Mäder, personal communication). However, the cultivation of root crops (potatoes, sugar beet; rotations no 3 and 5) would disturb the soil and largely offset improvements in soil structure. Also, the monoculture of maize (model rotation no 6) was assumed to have a negative effect on soil cover and soil fertility. In the organic model rotations, soil management was the same in the non-GM and GM scenarios so that no impact was expected.

\subsubsection{Impact of altered weed management on water quality}

In no-till systems, nitrate leaching into ground water is expected to be lower than in minimum tillage, due to the undisturbed soil structure and improved water-holding capacity of no-till soils. In addition, an increase in soil organic matter and microbial biomass in the uppermost layers may bind mobile elements either in exchangeable or in biological form, thus preventing their leaching to deeper soil layers and to underground aquifers or surface water bodies. However, field studies do not always support these expectations. In a Danish study, soil cultivation increased leaching on sandy loam but not on coarse sand (Møller and Djurhuus 1997). A study conducted in the Swiss plateau failed to demonstrate any clear impact of soil cultivation on nitrate leaching (Anken et al. 2003, 2004). The authors also state that the extant literature does not allow for any clear conclusions on this issue.

\subsubsection{Impact of altered weed management on fuel use}

In the model rotations, non-GM crops are managed with minimum tillage, while the corresponding HT crops are 
direct drilled. This saves approximately $201 /$ ha fuel (Brookes and Barfoot 2005). The reduction in spray passages (mainly in GM potatoes) also saves some fuel, but less than no-till management.

\subsubsection{Impact of altered weed management on climate gas emissions}

Agricultural activities interfere with $\mathrm{C}$ fluxes between the soil and the atmosphere, and may thus (positively or negatively) influence the availability of carbon dioxide and methane, two gasses of major importance for the global climate. No-till crop management increases soil organic carbon. The $\mathrm{C}$ fluxes associated with changes in soil $\mathrm{C}$ stocks are unknown. According to Paustian (2005), reduced tillage leads to $9 \%$ higher $\mathrm{C}$ stocks in the top soil, while notill leads to $16 \%$ higher $\mathrm{C}$ stocks in comparison with conventional tillage under temperate moist conditions. According to Brookes and Barfoot (2005), reduced tillage saves $100 \mathrm{~kg}$ carbon/ha annually, while no-till saves $300 \mathrm{~kg}$, and conventional tillage delivers $100 \mathrm{~kg}$ under North American conditions.

Agricultural activities may also influence emissions of nitrous oxide $\left(\mathrm{N}_{2} \mathrm{O}\right)$, another gas with relevance for the global climate. $\mathrm{N}_{2} \mathrm{O}$ emissions are greater in no-till systems (Steinbach and Alvarez 2006). According to the calculations by Steinbach and Alvarez (2006) for the Argentine Pampas, $\mathrm{N}_{2} \mathrm{O}$ emissions might overcome the beneficial effect of $\mathrm{C}$ sequestration in about 35 years, and the net effect of no-till might contribute to an increase in global warming. Given these contrasting trends and uncertainties, no estimates of the potential impacts on climate gas emissions were attempted in this study.

\subsection{Environmental impact of Bt arable crops}

The proportion of $\mathrm{Bt}$ maize in the model rotations varied between 0 and $100 \%$ (see Table 27), while Bt potato reached a maximum of $25 \%$ in the model rotations. Because $\mathrm{Bt}$ maize and $\mathrm{Bt}$ potato produce different toxins which are active against different insect taxa, they are discussed separately here.

\subsubsection{Occurrence of Bt toxins in plant tissues}

Most of the GM varieties of maize contain $\mathrm{Bt}$ toxins in all tissues (roots, shoots, leaves, pollen, seeds...), while in the variety "Mon 810", the toxin is not present in all tissues (see, e.g., Felke and Langenbruch 2005). For toxicity to Lepidoptera, the presence of toxin in the pollen is particularly critical (Felke and Langenbruch 2005).

In this study, the expression of Bt genes in different plant tissues was not specified for the GM model crops. As a worst case scenario, it was assumed that Bt toxins were present in all plant tissues. However, there would be a potential to mitigate the worst case scenario by authorizing only GM varieties which do not express $\mathrm{Bt}$ genes in the tissues responsible for a given effect (pollen, roots).

\subsubsection{Fate of Bt toxins in the environment and the food chain}

Different plant tissues enter the environment via different routes. For example, pollen is dispersed by the wind and/or bees and can travel considerable distances (but in small quantities), while leaves and roots mainly contaminate the soil where the crop grows (albeit in much larger amounts). For an example of dispersal of maize pollen, see Hofmann et al. (2008); for transport of maize leaves and cobs in rivers, see Rosi-Marshall et al. (2007) and Tank et al. (2010).

Bt toxins can be transmitted through the food chain. They have been detected in the bodies of herbivores from various (but not all) taxa (Dutton et al. 2002; Harwood et al. 2005; Obrist et al. 2006; Büchs et al. 2009), and also in various (but not all) taxa of predatory arthropods (Dutton et al. 2002; Harwood et al. 2005; Zwahlen and Andow 2005; Obrist et al. 2006; Harwood et al. 2007; Peterson et al. 2009).

When tissues of Bt crops fall to the ground and decompose, the Bt toxins are incorporated into the soil. For a long time, it was assumed that Bt toxins break down rapidly in the soil. However, Bt toxins which are bound to soil particles escape degradation and remain active (Stotzky 2004). The Cry1 Ab protein had no consistent effect on soil organisms (earthworms, nematodes, protozoa, bacteria, fungi). Recent research suggests that, under conditions of high $\mathrm{pH}$, the $\mathrm{Bt}$ toxins can solubilize and become available in the environment again, and that they are still toxic to target organisms (Sander, personal communication). Icoz and Stotzky (2008) found that Bt toxins had only small or negligible effects on soil micro-organisms such as woodlice (isopods), collembolans, mites, earthworms, and protozoa and on various enzymes in the soil. Kravchenko et al. (2009) found that Bt maize had no effects on total soil $\mathrm{C}$, mineralized $\mathrm{C}$, and soil $\mathrm{N}$ after 7 years of continuous cropping. Icoz et al. (2008) found that four consecutive years of Bt maize had no consistent effects on different groups of soil microorganisms or on enzyme activity. In a review, Bruinsma et al. (2003) conclude that most studies fail to demonstrate a definitively negative, positive, or neutral impact of GM crops and propose a case-by-case assessment. Recent research under controlled conditions also supports the view that Bt maize has few or no effects on soil microbiota, even after repeated cultivation or in soils with different degrees of fertility (Fliessbach et al. 2012).

Water may be polluted with $\mathrm{Bt}$ toxins from tissues of $\mathrm{Bt}$ crops or from soil particles to which Bt toxins are bound. 
For a case study on the dispersal of maize pollen, leaves, and cobs into headwater streams, see Rosi-Marshall et al. (2007). Among aquatic organisms, caddiesflies are the taxonomic group which is most closely related to lepidopterans, and Rosi-Marshall et al. (2007) found that they feed on pollen grains and maize plant tissue transported into rivers. In laboratory feeding trials, the leaf-shredding caddisfly Lepidostoma liba had 50\% lower growth when fed with litter from Bt maize, although mortality was not significantly affected. For the algal-scraping caddisfly Helicopsyche borealis, increased mortality was also demonstrated, but only at concentrations of Bt pollen three times higher than those measured in the field (Rosi-Marshall et al. 2007). Bøhn et al. (2008) reported that Daphnia magna fed with $100 \%$ transgenic Bt maize had lower fitness than when fed with non-Bt maize. The potential impact of these findings on headwater and downstream ecosystems is unknown at present.

\subsubsection{Toxic effects of Bt toxins on nontarget organisms}

The Bt toxins present in lepidopteran-specific GM maize are known to be active against caterpillars (Lepidoptera). In addition, they are also active against aquatic larvae of caddiesflies (Trichoptera), which are closely related to the Lepidoptera (Rosi-Marshall et al. 2007). The Bt toxins present in GM potato and in GM maize are known to be active against some beetles (Coleoptera). Diptera-specific $\mathrm{Bt}$ toxins exist in nature and are used as microbial insecticides, but have not been engineered into GM crops so far. Nontarget organisms from other taxa suffer much less from direct toxic effects of Bt proteins. Whether or not Bt toxins have a direct toxic effect on Neuroptera is a matter of considerable dispute among scientists (Hilbeck et al. 1998a, b, 1999; Romeis et al. 2004; Rodrigo-Simon et al. 2006). In the context of this project, it was not possible to resolve the controversy, but the possible nontarget effects on Neuroptera were not considered to be significant. Similarly, it was not possible to resolve whether lepidopteran-active Bt toxins have an effect on the coccinellid beetle Adalia bipunctata (Schmidt et al. 2009; Alvarez-Alfageme et al. 2011).

Whether a nontarget organism is affected by Bt crops depends not only on its sensitivity towards the toxin but also on the degree of exposure. By definition, nontarget insects do not feed on a crop. However, there are other routes of exposure to the toxin: for example, maize pollen can be deposited on the leaves of wild plants growing near a maize field and be consumed by caterpillars along with the wild plant's foliage. Caterpillars of the swallowtail (Papilio machaon) feeding on leaves dusted with pollen from $\mathrm{Bt}$ maize had reduced larval body mass and development, smaller adult size and body mass and lower survival (Lang and Vojtech 2006). Similar effects were found for a number of butterfly species occurring in southern Germany (Felke and Langenbruch 2005). The susceptibility of individual species varied greatly.

Laboratory and field studies may lead to different conclusions. Duan et al. (2010) conclude that laboratory studies with Bt crops show effects that are consistent with or more conservative than those found in field studies. Lang and Otto (2010) found that Bt maize affected nontarget Lepidoptera in $52 \%$ of the laboratory and $21 \%$ of the field observations. A caveat to laboratory studies is that they should expose nontarget organisms in the full variety of relevant ecological contexts, which may include indirect exposure via an intervening trophic level. One drawback of many field studies is their lower statistical power in comparison to laboratory experiments.

\subsubsection{Indirect effects mediated by the availability of prey or hosts}

The green lacewing, Chrysoperla carnea, was negatively affected when preying on lepidopteran larvae that had been fed with Bt maize (Hilbeck et al. 1998a, 1998b; Hilbeck et al. 1999). One hypothesis is that $C$. carnea is not sensitive to the $\mathrm{Bt}$ toxin, but that the effect was mediated by the nutritional value of the prey (Romeis et al. 2004). For the model conditions, such indirect effects were considered to be of low importance.

\subsubsection{Effects of altered insecticide use in Bt crops}

The comparison of non-Bt and Bt crops depended greatly on the context. When the non-Bt crops were not sprayed with insecticides (which was often the case under the model conditions), there was very little potential for Bt crops to reduce the environmental impact.

Maize In the model rotations, the non-GM scenario assumed that the corn borer was controlled by releasing Trichogramma. Under these conditions, there was no beneficial environmental effect of Bt maize. As a variant, nonGM maize was sprayed with insecticides. In this case, $\mathrm{Bt}$ maize had the environmental advantage of replacing an insecticide spray. The use of insecticides against the corn borer is rare in Europe (Wolf and Albisser Vögeli 2009).

Potatoes In the model rotations, Bt potato replaced a $\mathrm{Bt}$ spray in the organic system and an insecticide spray in the integrated system. Thus, a significant environmental benefit of Bt potato could only be expected for the integrated system.

In a meta-analysis of arthropod functional guilds, LaReesa Wolfenbarger et al. (2008) found the following: (1) predators were less abundant in (unsprayed) Bt cotton than in unsprayed non-Bt cotton; (2) predators and herbivores 
were more frequent in (unsprayed) Bt crops than in sprayed non-Bt crops; and (3) no differences were found when both $\mathrm{Bt}$ and non-Bt crops were sprayed. The authors conclude that both Bt toxins and insecticides may influence arthropods, but that the effects of insecticides are much greater than those of Bt toxins. Similar results were reported for Bt cotton and Bt maize by Marvier et al. (2007).

5.4 Environmental impact of other traits in GM arable crops

\subsubsection{Effects of late blight resistance in potatoes}

The model GM potato occurred in only two of the model rotations and with low frequency (14-25\%; see Table 27). GM potatoes were sprayed less often with fungicides than the typical non-GM potatoes such as the variety Agria. However, some treatments were necessary to prevent pathogen resistance and to control secondary diseases (see Table 6 with accompanying text). In the organic system (rotation no 1), fungicide applications were reduced from five to two; in the integrated system (rotation no 4), they were reduced from eight to three. When a highly late blightresistant variety such as Naturella was assumed for the baseline scenario (sensitivity analysis), fungicide application was equal to GM potatoes.

Because of the low proportion of potatoes in the model rotations, these effects are of minor importance for the agroecosystem in comparison to the effects of weed management and of $\mathrm{Bt}$ toxins.

\subsubsection{Effects of nematode resistance in potatoes}

The model GM potato was assumed to be resistant to potato cyst nematodes as well. In Switzerland, outbreaks of these nematodes are prevented by wide crop rotations (potatoes planted once every 4 years at most) and by the widespread use of certified seeds. These measures have been in place for more than 50 years and have reduced the incidence of potato cyst nematodes to very low levels (e.g., four plots in Switzerland in the year 2007; Schaub and Auer 2008). Because of the low incidence of potato cyst nematodes, nematode resistance had no practical impact in the model rotations and did not alter the use of pesticides.

\subsubsection{Effects of rhizomania resistance in sugar beet}

The model GM sugar beet was assumed to be resistant to rhizomania (BNYVV). However, all varieties on the recommended list for Switzerland are tolerant to rhizomania (SFZ 2011). Thus, this GM trait has neither practical value nor any environmental impact under Swiss conditions.

\subsection{Environmental impact of simplifying rotations}

One of the main objectives of this study was to explore the potential changes in production systems over time (at field, farm, and landscape level) resulting from the introduction of GM crops. The scenarios developed in the agronomy workshops suggest that (1) the potential impact of GM crops depends on the production system and (2) that GM crops facilitate the general trend towards shorter crop rotations. The tendency towards larger fields is an independent trend with relevance for the landscape. It is worth noting that co-existence requirements favor larger field sizes (Hüsken et al. 2007).

Model rotation no 6 is a monoculture of maize and represents an extreme example of a shift from integrated to conventional crop management. For this rotation, negative effects were predicted on biodiversity of the arable flora, arthropods, and other wildlife as well as on the soil. If grown at larger scale, monocultures lead to a more large-scale structuring of the landscape. From an esthetic point of view, small-scale structuring is generally preferable to large-scale structuring.

In Switzerland, rotations are strictly regulated by the "ÖLN production rules". A simplification of rotations is possible only under conventional production. However, the transition from integrated to conventional production had additional side-effects: organic and integrated model farms were required to have a minimum percentage of "ecological compensation areas", while there was no such requirement for conventional farms. Because ecological compensation areas are particularly valuable habitats, their loss had a severe negative impact on the biodiversity of arable flora, arthropods and other wildlife, and also on the landscape.

5.6 Environmental impact of GM crops in the context of rotations

The frequency of GM traits in the model rotations is shown in Table 27 . The HT trait was very frequent (75-100\%) in the integrated and conventional model rotations. Thus, it was expected that the impacts of HT crops would be more severe over the model rotations than in a single cropping cycle. By contrast, the frequency of the Bt trait and other GM traits was relatively low. Thus, their impacts were less severe over the model rotations than in a single cropping cycle.

\subsection{Environmental impact of GM apples and model orchards}

\subsubsection{Impacts on undergrowth vegetation}

Neither the transgenes nor the associated changes in the fungicides and bactericides used had a direct impact on the undergrowth of the model orchards. However, all reductions in the number of spray passages will favor biodiversity in 
the undergrowth. The greater management flexibility in the GM scenarios allowed spraying to be done when conditions were more suitable and thus further increased biodiversity in the undergrowth between rows. The undergrowth within rows was not affected by management flexibility. Finally, biodiversity of the undergrowth vegetation was positively affected by scab resistance. With combined resistance to scab and fire blight, the effect was more pronounced.

\subsubsection{Impact on the vegetation in hedges and on meadow} trees

When entire model orchards were composed of fire blighttolerant varieties, wild host plants of fire blight could be tolerated in hedges and gardens nearby, and meadow trees did not pose an infection risk. Thus, biodiversity of the vegetation outside the orchard was assumed to be higher.

\subsubsection{Indirect impact of the vegetation on arthropods and wildlife}

As detailed in the previous sections, scab and fire blight resistance may increase biodiversity of the vegetation. This is likely to increase the biodiversity of arthropods and wildlife as well. "Weed strips" have been shown to promote beneficial arthropods in apple orchards (Wyss 1995), and hedges and meadow trees are well-known as highly valuable habitats.

\subsubsection{Direct impact of transgenes on arthropods}

The nontarget effects of scab-resistant GM apple tissue was tested by Vogler et al. (2010). Neither the apple leafminer Phyllonorycter blancardella (Lepidoptera: Gracillariidae) nor the parasitoid wasp Pholetesor circumscriptus (Braconidae) were negatively affected. No data were available for fire blight-resistant GM apples.

\subsubsection{Direct impact of plant protection products on non-target arthropods}

The nontarget effects of the fungicides and insecticides used in the model orchards are given in Table 28. The information was compiled from Höhn et al. (2010). No information was found for the products applied against fire blight.

Of the pesticides used in the organic model orchard, only sulfur at higher concentrations had substantial nontarget toxicity (toxic to predatory mites). The reduction of highly dosed sulfur by two thirds thus had a major beneficial effect on predatory mites but only a minor effect on other nontarget organisms. Because sulfur is a repellent for mammals, its reduction was also favorable for wildlife. All other pesticides had minor nontarget toxicity (none, N-M or M; for abbreviations, see Table 28). The reduction of some of the fungicides on scab-resistant varieties thus had only a minor beneficial effect on nontarget organisms.

Of the pesticides used in the integrated model orchard, captane, thiacloprid, and chlorpyriphos had severe toxicity to nontarget organisms. Reduction of the fungicide captane by one third thus had a major beneficial effect on hoverflies. The insecticides thiacloprid and chlorpyriphos had severe toxicity to several nontarget organisms but were not reduced on scabresistant varieties. In conclusion, the beneficial effect on hoverflies is expected to be relatively small in comparison to the remaining negative effects on flowerbugs, ladybirds and parasitoids (thiacloprid) and on lacewings and bees (chlorpyriphos).

\subsubsection{Impact on micro-organisms}

A great variety of micro-organisms live on the skin (epiphytes) and in the apple tissue (endophytes), and management system has a profound impact on epiphytic and endophytic microbial populations (Granado et al. 2008). Any changes in pesticide use, particularly the use of streptomycine, are likely to affect these micro-organisms. At present, very little is known about these micro-organisms, so this issue was not included in the present study. The novel gene products in GM apples are not expected to have any impact on microorganisms as compared to traditionally bred cultivars.

\subsubsection{Impact on the soil}

The reduction in the number of spray passages and the improved management flexibility of resistant varieties (both traits) reduced soil compaction. Thus, both resistance traits had an additive beneficial effect on soil structure.

Copper fungicides were completely eliminated on scabresistant varieties in the organic model orchard. The precise environmental impacts of copper fungicides are still under discussion. With respect to soil organisms, the European Food Safety Authority peer review identified a long-term risk to earthworms but found no evidence for negative effects on nitrification (EFSA 2008). Streptomycine was completely eliminated on fire blight-resistant varieties in the integrated model orchard. This was likely to be beneficial for soil bacteria, but experimental evidence is lacking. All other reductions of pesticides are unlikely to have a significant effect on the soil. The gene products of the model GM apples were not expected to have a significant effect on the soil.

\subsubsection{Impact on water}

The beneficial effects on soil structure (see above) positively affected the soil's capacity for water retention (also called "field capacity"). For leaching of pesticides into water, see the general discussion in the section on HT crops above. 
Table 28 Side-effects of the relevant fungicides and insecticides used in the model orchards on non-target arthropods
Effects are taken from Höhn et al. (2010). Only measurements showing a negative effect are given, while assessments " $N$ " are omitted to improve the legibility of the table

Effects are abbreviated as in the original publication: $N$ neutral to low toxicity $(0-40 \%$ reduction); $M$ medium toxicity (40-60\% reduction); $T$ toxic $(60-100 \%$ reduction). Effects on bees: $D$ dangerous. Severe effects (M-T, $\mathrm{T}$, or D) are shown in bold. For each pesticide, the number of applications on scab-susceptible and scab-resistant varieties is given (for details, see Tables 12 and 13)

\subsubsection{Impact on energy use}

The additive reduction of spray passages by both resistance traits reduces the use of energy. This relates to fuel use by machinery and the "grey energy" contained in the pesticides.

\subsubsection{Impact on landscape}

Meadow trees are an important and highly valued element of traditional landscapes in the Swiss lowlands. In areas of high fire blight pressure, however, they are currently regarded as a major source of inoculum. The replanting of meadow trees is recommended under the following conditions (Landwirtschaftliches Zentrum SG 2006): (1) the owner must be prepared to check the trees regularly for
Non-target effects

Number of applications

\begin{tabular}{|c|c|c|c|}
\hline \multicolumn{4}{|l|}{ Organic model orchard: fungicides } \\
\hline Kocide Opti (copper) & Lacewings: N-M & 3 & 0 \\
\hline \multirow[t]{2}{*}{ Schwefel Stulln (sulfur $<0.3 \%$ ) } & Predatory mites: $\mathrm{M}$ & 4 & 0 \\
\hline & Ladybirds: M & & \\
\hline \multirow[t]{3}{*}{ Schwefel Stulln (sulfur $>0.4 \%$ ) } & Predatory mites: $\mathbf{T}$ & 16 & 5 \\
\hline & Ladybirds: M & & \\
\hline & Parasitoids: $\mathrm{M}$ & & \\
\hline Myco-Sin (acidified clay) & Predatory mites: $\mathrm{M}$ & 9 & 5 \\
\hline Armicarb (potassium bicarbonate) & None & 5 & 6 \\
\hline \multicolumn{4}{|l|}{ Organic model orchard: insecticides } \\
\hline Madex 3 (granulosis virus) & None & 1 & 1 \\
\hline \multirow[t]{3}{*}{ NeemAzal-T/S (azadirachtin) } & Lacewings: $\mathrm{M}$ & 1 & 1 \\
\hline & Hoverflies: M & & \\
\hline & Parasitoids: N-M & & \\
\hline Quassan (quassia) & None & 1 & 1 \\
\hline \multicolumn{4}{|l|}{ Integrated model orchard: fungicides } \\
\hline Delan WG (dithianone) & None & 4 & 2 \\
\hline Captan 80 (captane) & Hoverflies: M-T & 6 & 4 \\
\hline Slick (difenoconazole) & Flower bugs: $\mathrm{M}$ & 2 & 2 \\
\hline \multirow[t]{2}{*}{ Flint (trifloxystrobine) } & Flower bugs: $\mathrm{M}$ & 4 & 4 \\
\hline & Lacewings: N-M & & \\
\hline \multicolumn{4}{|l|}{ Integrated model orchard: insecticides } \\
\hline \multirow[t]{4}{*}{ Alanto (thiacloprid) } & Flower bugs: M-T & 3 & 3 \\
\hline & Lacewings: $\mathrm{M}$ & & \\
\hline & Ladybirds: M-T & & \\
\hline & Parasitoids: $\mathrm{M}-\mathrm{T}$ & & \\
\hline Madex 3 (granulosis virus) & None & 6 & 6 \\
\hline \multirow[t]{5}{*}{ Pyrinex (chlorpyrifos) } & Predatory mites: N-M & 2 & 2 \\
\hline & Flower bugs: $\mathrm{M}$ & & \\
\hline & Lacewings: $\mathbf{T}$ & & \\
\hline & Ladybirds: N-M & & \\
\hline & Bees: D & & \\
\hline
\end{tabular}

fire blight, (2) varieties must have as low sensitivity as possible, (3) meadow trees should be planted at least $500 \mathrm{~m}$ away from commercial apple orchards or tree nurseries, and (4) integration into existing stands of meadow trees is preferable. The introduction of fire blighttolerant apple varieties would improve apple growers' tolerance towards meadow trees.

\section{Discussion}

The aim of this study was to carry out an ex ante assessment of the potential agronomic, socio-economic, and agro-ecological impacts of the cultivation of GM crops in Switzerland. The assessment method used was robust, tolerates missing, 
incomplete, imprecise and even controversial data, and considers GM crops in a wider context including alternative agricultural practices, ecosystem management, and agricultural policy. The study included information from literature sources as well as expert opinions elaborated in workshops. It was based on realistic scenarios of novel agricultural practices associated with the use of GM crops and specifically tailored to farming conditions in Switzerland. Cumulative effects expected for entire model rotations/orchards and interactions with and farming systems (organic, integrated, conventional) were included in the assessments.

The findings did not all point in the same direction. For the model arable rotations, the economic benefit due to GM crops (all traits) was only marginal. By contrast, the environmental impact was more substantial and included negative effects on biodiversity as well as positive effects on the soil. Both of these effects were a consequence of altered weed management in HT crops, and both effects were boosted by the frequent occurrence of HT crops in the model rotations. These effects did not occur in the organic model rotations, where no HT crops were grown. In the conventional model rotations, profitability was low due to the lack of direct payments while negative environmental effects were aggravated because of the loss of ecological compensation areas and, in one case, due to monoculture of maize as well. Late blight-resistant potatoes (regardless of whether they were GM or conventionally bred) needed fewer fungicide sprays than susceptible varieties. Under organic management, late blight-resistant potatoes were also more profitable due to an increase in marketable yield. Because potatoes made up only a small proportion of the model rotations, the effects at the rotation level were limited. In apple, resistance to scab and to fire blight improved profitability and had a positive environmental impact. These effects were more pronounced in the organic than in the integrated model orchard. Scab resistance is also available from classical breeding and had the same effect as GM resistance. These results support the hypothesis that the impact of GM crops and traits is context sensitive (Russell 2008). This explains why the estimated impact of GM crops for Switzerland differs from the experience in some other countries (see below).

The potential impacts of GM plants on Swiss agriculture have been the subject of a few other studies:

Crop management and yield: Hütter et al. (2000) concluded that Bt potatoes could avoid the use of insecticides, while Bt maize would not reduce insecticide use. Wolf (2009) concluded that the use of HT crops leads neither to yield increases nor to reductions in long-term herbicide use. He further concluded that the main benefits arise from the facilitation of no-till management and from simplified weed control (management flexibility). These conclusions accord with those of the present study.
Profitability: Hütter et al. (2000) concluded that GM pest-resistant varieties would only be profitable if grown on large surfaces, which accords with our evaluation of the socio-economic impacts. Wolf and Albisser Vögeli (2009) concluded that Bt maize delivers increased yields only under high to very high infestation pressure of the corn borer, which is not the case for most of Switzerland. They also found a price premium of one third for GM seeds, which corresponds to the assumptions in this study. Mann (2011) concluded that the cultivation of GM maize would not be profitable under Swiss conditions, taking into account the price premium for seeds and the costs of co-existence.

Environmental risks: In an early study, Hütter et al. (2000) explored the ecological consequences of GM pest-resistant crop plants in Switzerland. For outcrossing and establishment of GM maize, GM potato, and GM oilseed rape, they come to similar conclusions as this study. Their conclusion that Bt potato could avoid the use of insecticides while Bt maize would not reduce insecticide use also supports our findings. Tappeser et al. (2000) identified very similar environmental risks as were found in this study. Sanvido et al. $(2005,2006)$ assume no relevant negative impacts on the environment (i.e., soil organisms, nontarget organisms, gene flow, invasiveness).

A range of GM arable crops suited to the climatic conditions in Switzerland was found to be available within the next decade. However, the range of productivity-related traits was very limited, comprising mainly herbicide tolerance and pest resistance based on Bt. Perennial crops with resistance to key pests and diseases are still under development; commercially available varieties were not expected within the next decade.

In conclusion, GM crops had a very limited potential impact on the sustainability of Swiss agriculture. They did not solve major production bottlenecks (except for fire blight resistance, which is not commercially available) and had only a minor influence on farm profitability. Their environmental and socio-economic impacts were variable. All potential impacts of GM crops and traits were context sensitive.

\subsection{Is Swiss agriculture different from other countries?}

In some countries, GM arable crops (HT and HT/Bt) were adopted very rapidly after their introduction (e.g., Brookes and Barfoot 2005; James 2010). This suggests that their cultivation has major agronomic and/or socio-economic advantages in the countries concerned (e.g., Gianessi 2008; Park et al. 2011). By contrast, this project found only minor agronomic and socio-economic advantages for many GM arable crops under the model conditions. Other studies under Swiss conditions came to similar conclusions (Wolf 2009; Wolf and Albisser Vögeli 2009; Mann 2011). This 
suggests that the agricultural context is different in Switzerland than in the main GM crop adoption countries (USA, Canada, Argentina, Brazil, and Spain).

The following characteristics of Swiss agriculture might explain these differences: (1) field sizes are much smaller in Switzerland than in the USA, Canada, Brazil, and Argentina. In very large fields, management flexibility is crucial, no-till is much more efficient than any other form of tillage, and spray passages should be kept to a minimum. (2) Due to diverse crop rotations and the climate, the populations of the European corn borer are smaller in Switzerland and usually exhibit fewer generations per year than in Spain or the USA. Thus, corn borer resistance (Bt maize) is less important in Switzerland. (3) In Switzerland, direct payments make up a large proportion of the net margin. Thus, the relative importance of yield increases is smaller than in countries without direct payments (e.g., maize in Switzerland vs. in Spain). (4) Swiss agricultural policy is aimed at achieving environmentally friendly production, and direct payments are tied to production rules which exclude intensive production and simple rotations. (5) For the economic calculations, we assumed that the "original" herbicides had to be used on HT crops (RoundUp for glyphosate, Basta for glufosinate). These are more costly than other products with the same active ingredients. In the longer term (but outside the study period), other herbicides are likely to be used that will improve the profitability of GM crops by approximately $100 \mathrm{CHF} / \mathrm{ha}$ in comparison to the data shown here.

6.2 Influence of model assumptions and system boundaries on the results

The agronomic and economic assumptions for the model arable crops and the model orchards were based on expert knowledge and practical experience. The only exception is fire blight, which is new in Switzerland and still spreading. At present, it is difficult to estimate the incidence of fire blight and its impact on the longer-term situation.

GM apples were included in this study in order to cover a wider range of crops that are important in the Swiss context. As stated above, it was uncertain whether GM apples will be commercialized within the study period. It was noted that the 10 years duration of registration for GMOs is very short in comparison to the time needed for multiplication of apple trees to full yield of an orchard, and that registration costs largely exceed the potential benefit for the breeder. This constitutes a great risk for the applicant, the tree nurseries and the apple growers alike.

\subsubsection{Consumer acceptance of GM foods}

Despite considerable efforts over more than a decade, it has been very difficult to convince consumers (and retailers) that scab-resistant varieties should be consumed in preference to susceptible varieties in order to favor ecologically friendly production. Based on this experience, the experts had doubts whether arguments of resistance to scab and/or fire blight would be successful in convincing consumers to buy GM apples. The same is true of potatoes.

The economic calculations were biased in favor of GM crops by the system boundaries. First, all costs for coexistence (for the farmer, as well as for neighbors, trade, processors, and the government) were excluded. This is particularly relevant for Switzerland, where field sizes are often small. The co-existence costs for farmers growing GM maize in Switzerland were recently estimated at approximately 90$900 \mathrm{CHF} / \mathrm{ha}$, depending on the scenario (Mann 2011). There is no estimate of the co-existence costs for other farmers (e.g., organic farmers) and for the public. Second, the model calculations were based on the assumption that consumers would fully accept GM foods. At present, this would clearly not be the case. Again, this is particularly relevant for Switzerland, because GM foods must be labeled as such.

We decided to assess the potential impact of GM crops on organic production systems as well. However, all national and international standards and regulations on organic production currently prohibit the use of GMOs.

This study was limited to agricultural crops with production-related GM traits. Other traits of agricultural crops (e.g., prolonged shelf live) and other crops (e.g., "pharmacrops") were not studied. The conclusions of this study probably cannot be extrapolated to such crops.

\subsection{Compliance of GM crops with Swiss agricultural policy}

Swiss agricultural policies (“AP 2014-2017") have the following major goals: (1) security of food supplies; (2) conservation of natural resources, ecology; (3) maintenance of area under agricultural production; (4) animal welfare; (5) economically viable production; and (6) social welfare. In this section, the findings of this study are reviewed with respect to these goals.

Secure food supplies None of the GM crops studied solved a major production bottleneck in Swiss agriculture, except for fire blight-resistant apples, for which commercialization is still a long way off. Substantial yield increases resulted only in organic apple and potato production, where resistance was more effective than the present control measures for scab and late blight. However, the same effect could also be obtained by classical breeding for resistance. The other GM traits had no impact on the security of food supplies.

Conservation of natural resources, ecology In arable crops, the impact of GM crops was driven mainly by the altered soil and weed management strategies associated with HT crops. While no-till soil management benefited soil 
conservation, the highly efficient weed control reduced biodiversity. These effects accumulated over time due to the high proportion of HT crops in the integrated and conventional model rotations. In organic production systems, the effects were less pronounced, mainly due to non-use of herbicides. Transition from integrated to conventional production had a serious, negative impact on the environment. However, the economic calculations showed that such transitions would not be profitable and were thus unlikely to occur. In apple production systems, scab and fire blight resistance had a positive impact on natural resources as well as ecology due to the reduced need for spray passages and pesticide use. This demonstrated the ecological value of growing resistant varieties in perennial crops. In conclusion, the ecological impacts identified in this study were highly context sensitive and were associated mainly with altered production systems rather than with the GM crops per se.

Maintenance of area under agricultural production This goal concerns the maintenance of agriculture in alpine regions, on which the model GM crops had no impact.

Animal welfare The model GM crops had no impact on animal welfare.

Economics Most GM traits (with the exception of late blight resistance) had only a small impact on the net margin of arable crops, while the resistance traits in apples improved profitability considerably. The same effect could also be obtained by classical breeding for resistance.

Social welfare Both positive and negative impacts on social welfare were identified. On the positive side, greater management flexibility was identified as the major socioeconomic impact of all GM crops. On the negative side, varietal choice would probably be very limited for GM crops. If GM maize, oilseed rape, or apples were grown, the presence of GM pollen in honey would be unavoidable. However, fire blight-resistant apples would reduce the probability of streptomycine residues in honey. Finally, the trait of herbicide tolerance would lead to a tighter integration of farmers into the agro-chemical production chain, where buyers of GM seeds are obliged to use certain herbicides.

Acknowledgments We warmly thank Gregor Albisser Vögeli, Daniel Ammann, Broder Breckling, Fabio Cerutti, Dirk Dobbelaire, Othmar Eicher, Andreas Fliessbach, Klaus Gersbach, Markus Hardegger, Thomas Imhof, Andreas Keiser, Carlo Leifert, Jan Lucht, Pia Malnöe, Stefan Mann, Urs Niggli, Karin Nowack, Lukas Pfiffner, Andrea Raps, Beatrix Tappeser, Wim Verbeke, Ueli Voegeli, Christian Vogt, and Claudia Zwahlen for their active participation in the project workshops. Christopher Hay critically reviewed the manuscript. This project was funded by the Swiss National Science Foundation in the framework of NRP59 (grant no 405940-115674 to L. Tamm).

\section{References}

ACRE (2007) Managing the footprint of agriculture: towards a comparative assessment of risks and benefits for novel agricultural systems. Report of the ACRE sub-group on wider issues raised by the Farm-Scale Evaluations of herbicide tolerant GM crops

AGPM (2007) Guide de bonnes pratiques pour la culture du maïs bt AGPM. Association Générale des Producteurs de Maïs, Paris

Alvarez-Alfageme F, Bigler F, Romeis J (2011) Laboratory toxicity studies demonstrate no adverse effects of cry $1 \mathrm{Ab}$ and cry $3 \mathrm{Bb} 1$ to larvae of Adalia bipunctata (Coleoptera: Coccinellidae): the importance of study design. Transgenic Res 20:467-479. doi:10.1007/s11248-010-9430-5

Anken T, Irla E, Heusser J, Ammann H, Richner W, Walther U, Weisskopf P, Nievergelt J, Stamp P, Schmid O, Mäder P (2003) Einfluss der Bodenbearbeitung auf die Nitratauswaschung. FATBerichte Nr. 598. FAT, Tänikon

Anken T, Stamp P, Richner W, Walther U (2004) Pflanzenentwicklung, Stickstoffdynamik und Nitratauswaschung gepflügter und direktgesäter Parzellen. FAT-Schriftenreihe Nr. 63. Agroscope FAT, Tänikon

ARE (2004) Nachhaltigkeitsbeurteilung: Rahmenkonzept und methodische Grundlagen. Bundesamt für Raumentwicklung (ARE), Bern

Bartsch D, Schmidt M (1997) Influence of sugar beet breeding on populations of Beta vulgaris ssp. maritima in Italy. J Veg Sci 8:81-84. doi: $10.2307 / 3237245$

Bartsch D, Dietz-Pfeilstetter A, Koenig R, Schuphan I, Smalla K, Wackernagel W (1999) Wissenschaftliche Begleitung von Freilandversuchen mit Rhizomania-resistenten Zuckerrüben. BMBFStatusseminar. Bundesministerium für Bildung und Forschung BMBF, http://www.biosicherheit.de/pdf/proceedings 99/ 15Bartsch.pdf, pp. 65-76

Beckie HJ, Séguin-Swartz G, Warwick SI, Johnson E (2004) Multiple herbicide-resistant canola can be controlled by alternative herbicides. Weed Sci 52:152-157. doi:10.1614/P2002-163

Benbrook CM (2004) Genetically engineered crops and pesticide use in the United States: the first nine years. BioTech InfoNet Technical Paper Number 7

Bigler F, Fischer D, Sanvido O, Stark M, Vogel B, Wiesendanger B (2008) Grundlagen für ein Umweltmonitoring unbewilligter gentechnisch veränderter Pflanzen im Kanton Zürich. ARTSchriftenreihe 8. Forschungsanstalt Agroscope ReckenholzTänikon ART, Ettenhausen

Bindraban PS, Franke AC, Ferrar DO, Ghersa CM, Lotz LAP, Nepomuceno A, Smulders MJM, van den Wiel CCM (2009) GM-related sustainability: agro-ecological impacts, risks and opportunities of soy production in Argentina and Brazil. Plant Research International B.V., Report 259, Wageningen

Binimelis R, Pengue W, Monterosso I (2009) "Transgenic treadmill": responses to the emergence and spread of glyphosate-resistant johnsongrass in Argentina. Geoforum 40:623-633. doi:10.1016/ j.geoforum.2009.03.009

BLW (2005) Agrarbericht 2005 des Bundesamtes für Landwirtschaft. Bundesamt für Landwirtschaft (BLW), Bern

Bøhn T, Prinicerio R, Hessen DO, Traavik T (2008) Reduced fitness of Daphnia magna fed a Bt-transgenic maize variety. Arch Environ Contam Toxicol 55:584-592. doi:10.1007/s00244-008-9150-5

Borggaard OK, Gimsing AL (2008) Fate of glyphosate in soil and the possibility of leaching to ground and surface waters: a review. Pest Manag Sci 64:441-456

Botta F, Lavison G, Couturier G, Alliot F, Moreau-Guigon E, Fauchon N, Guery B, Chevreuil M, Blanchoud H (2009) Transfer of glyphosate and its degradate AMPA to surface waters through urban sewerage systems. Chemosphere 77:133-139. doi:10.1016/ j.chemosphere.2009.05.008 
Bravin E, Eicher O, Goldenberger M, Henauer U, Hollenstein R, Kilchenmann A, Maurer J, Mouron P, Rossier J, Zürcher M (2009) Die Bewertung der Obstkultur. Flugschrift Nr. 61. Agroscope Changins-Wädenswil ACW

Bravin E, Mencarelli Hoffmann D, Kockerols M, Weibel FP (2010) Economics evaluation of apple production systems. Proceedings of the Organic Fruit Conference. Acta Horticult 873:219-225

Brookes G, Barfoot P (2005) GM crops: the global economic and environmental impact - the first nine years 1996-2004. AgBioforum 8:187-196

Brooks DR et al (2003) Invertebrate responses to the management of genetically modified herbicide-tolerant and conventional spring crops. I Soil-surface-active invertebrates. Philos Trans R Soc Lond B 358(1439):1847-1862

Bruinsma M, Kowalchuk GA, Van Veen JA (2003) Effects of genetically modified plants on microbial communities and processes in soil. Biol Fertil Soils 37:329-337

Büchs W, Prescher S, Schlein O (2009) Does Diabrotica-resistant Bt maize promote pests like fruit flies and aphids? Indications from biosafety research on effects of cry3Bb1-Bt-maize on Diptera insect pathogens and insect parasitic nematodes. IOBC/wprs Bulletin vol. 45. IOBC, pp. 170

Butler SJ, Vickery JA, Norris K (2007) Farmland biodiversity and the footprint of agriculture. Science 315:381-384. doi:10.1126/ science. 1136607

Cakmak I, Yaziki A, Tutus Y, Ozturk L (2009) Glyphosate reduced seed and leaf concentrations of calcium, manganese, magnesium, and iron in non-glyphosate resistant soybean. Eur J Agron 31:114-119. doi:10.1016/j.eja.2009.07.001

Carpenter J, Gianessi L (1999) Herbicide tolerant soybeans: why growers are adopting Roundup Ready varieties. AgBioforum 2:65-72

Ceddia MG, Bartlett M, Perrings C (2007) Landscape gene flow, coexistence and threshold effect: the case of genetically modified herbicide tolerant oilseed rape (Brassica napus). Ecol Model 205:169-180. doi:10.1016/j.ecolmodel.2007.02.025

Cellini F, Chesson A, Colquhoun I, Constable A, Davies HV, Engel KH, Gatehouse AMR, Kàrenlampi S, Kok EJ, Leguay JJ, Lehesranta S, Noteborn HPJM, Pedersen J, Smith M (2004) Unintended effects and their detection in genetically modified crops. Food Chem Toxicol 42:1089-1125. doi:10.1016/j.fct.2004.02.003

Chamberlain DE, Freeman SN, Vickery JA (2007) The effects of GMHT crops on bird abundance in arable fields in the UK. Agric Ecosyst Environ 118:350-356. doi:10.1016/j.agee.2006.05.012

Chapman MA, Burke JM (2006) Letting the gene out of the bottle: the population genetics of genetically modified crops. New Phytol 170:429-443. doi:10.1111/j.1469-8137.2006.01710.x

Colbach N (2009) How to model and simulate the effects of cropping systems on population dynamics and gene flow at the landscape lavel: example of oilseed rape volunteers and their role for co-existence of GM and non-GM crops. Environ Sci Pollut Res 16:348-360

Copeland JE, Daems W, Demont M, Dillen K, Gylling M, Kasamba E, Mathijs E, Menrad K, Oehen B, Petzoldt M, Sausse C, Stolze M, Tollens E (2007) Costs of measures to ensure co-existence and economic implications of adventitious admixtures in different systems. Sustainable Introduction of GMOs into European Agriculture (SIGMEA) Deliverable D5.2 \& D5.3. University of Applied Sciences Weihenstephan, Germany

Daems W., M. Demont, K. Dillen, E. Mathijs, SausseC., E. Tollens. (2007) Economics of spatial coexistence of transgenic and conventional crops: oilseed rape in Central France. Faculty of Bioscience Engineering, Katholieke Universiteit Leuven, Leuven, NL

Delabays N, Auer J (2009) Eine neue exotische Pflanze etabliert sich in den Weinbaugebieten: Das südamerikanische Berufskraut. Agroscope News-Service http://www.news-service.admin.ch/NSBSubscriber/ message/de/28887. Accessed 17 Mar 2010
Derron JO, Goy G, Breitenmoser S (2009) Caractérisation biologique de la race de la pyrale du maïs (Ostrinia nubilalis) à deux générations présente dans le Bassin lémanique. Rev Suisse Agric 41:179-184

Dewar AM, May MJ, Woiwod IP, Haylock LA, Champion GT, Garner BH, Sands RJN, Qi A, Pidgeon JD (2003) A novel approach to the use of genetically modified herbicide tolerant crops for environmental benefit. Proc R Soc Lond B 270:335-340

Duan JJ, Lundgren JG, Naranjo S, Marvier M (2010) Extrapolating non-target risk of $B t$ crops from laboratory to field. Biol Lett 6:74-77

Duke SO, AL Cerdeira, (2005) Potential environmental impacts of herbicide-resistant crops. Collection of biosafety reviews. Vol 2. International Centre for Genetic Engineering and Biotechnology (ICGEB), Trieste, Italy, pp. 66-143

Duke SO, AL Cerdeira (2005) Transgenic herbicide-resistant crops: current status and potential for the future. Outlooks on Pest Management, August 2005, 1-4

Dutton A, Klein H, Romeis J, Bigler F (2002) Uptake of Bt-toxin by herbivores feeding on transgenic maize and consequences for the predator Chrysoperla carnea. Ecol Entomol 27:441-447. doi:10.1046/j.1365-2311.2002.00436.x

Econopouly BF, McKay JK, Westra P, Lapitan NL, Chapman L, Byrne PF (2011) Backcrossing provides an avenue for gene introgression from wheat to jointed goatgrass (Aegylops cylindrica) in the U.S. Great Plains. Weed Sci 59:188-194. doi:10.1614/WS-D-10-00141.1

EFSA (2008) Conclusion on pesticide peer review regarding the risk assessment of the active substance copper (i), copper (ii) variants namely copper hydroxide, copper oxychloride, tribasic copper sulfate, copper (i) oxide, Bordeaux mixture. EFSA Sci Rep 187:1-101

EUROSTAT (2009) Price indices of the means of agricultural production. EUROSTAT, Luxembourg. http://appsso.eurostat.ec.euro pa.eu/nui/show.do?dataset=apri pi05 ina\&lang=en. Accessed on 16 July 2010

Feil B, Schmid JE (2001) Pollenflug bei Mais, Weizen und Roggen. Shaker, Aachen

Felke M, Langenbruch GA (2005) Auswirkungen des Pollens von BtMais auf ausgewählte Schmetterlingslarven. BfN-Skripten 157. Bundesamt für Naturschutz, Bonn

Fliessbach A, Messmer M, Nietlisbach B, Infante V, Mäder P (2012) Effects of conventionally bred and Bacillus thuringiensis (Bt) maize varieties on soil microbial biomass and activity. Biol Fertil Soils. doi:10.1007/s00374-011-0625-6

Flisch R, Sinaj S, Charles R, Richner W (2009) GRUDAF 2009. Grundlagen für die Düngung im Acker- und Futterbau. Agrarforschung 16:4-97

Foresight Expert Group (2007) FFRAF report: foresighting food, rural and agri-futures. Standing Committee on Agricultural Research. http://ec.europa.eu/research/agriculture/scar/pdf/ foresighting food_rural and agri futures.pdf

Gaines TA, Henry B, Byrne PF, Westra P, Nissen J, Shanes DL (2008) Jointed Goatgrass (Aegylops cylindrica) by imidazolinoneresistant wheat hybridization under field conditions. Weed Sci 56:32-36. doi:10.1614/WS-07-033.1

Gessler C, Patocchi A, Sansavini S, Tartarini S, Gianfranceschi L (2006) Venturia inaequalis resistance in apple. Crit Rev Plant Sci 25:473-503

Gianessi LP (2008) Economic impacts of glyphosate-resistant crops. Pest Manag Sci 64:346-352. doi:10.1002/ps.1490

Gianessi LP, Silvers CS, Sankula S, Carpenter JE (2002) Plant biotechnology: current and potential impact for improving pest management in U.S. agriculture. An analysis of 40 case studies. National Center for Food and Agricultural Policy, Washington, DC

Gibbons DW, Bohan DA, Rothery P, Stuart RC, Haughton AJ, Scott RJ, Wilson JD, Perry JN, Clark SJ, Dawson JG, Firbank LG 
(2006) Weed seed resources for birds in fields with contrasting conventional and genetically modified herbicide-tolerant crops. Proc R Soc B 273:1921-1928

Gómez-Barbero M, Rodriguez-Cerezo E (2006) Economic impact of dominant GM crops worldwide: a review. European Commission, DG JRC, December 2006

Gómez-Barbero M, Rodruigez-Cerezo E (2007) GM crops in EU agriculture. A case study for the BIO4EU project. European Commission, DG JRC. Institute for Prospective Technology Studies. http://bio4eu.jrc.ec.europa.eu/documents/FINALGMcropsintheEU BIO4EU.pdf, Sevilla

Gomides FL, Singer H, Müller SR, Schwarzenbach RP, Stamm C (2008) Source area effects on herbicide losses to surface waters - a case study in the Swiss alps. Agric Ecosyst Environ 128:177-184

Granado J, Thürig B, Kieffer E, Petrini L, Fliessbach A, Tamm L, Weibel FP, Wyss GS (2008) Culturable fungi of stored 'golden delicious' apple fruits: a one-season comparison study of organic and integrated production systems in Switzerland. Microb Ecol 56:720-732. doi:10.1007/s00248-008-9391-x

Gruber S, Pekrun C, Claupein W (2004) Seed persistence of oilseed rape (Brassica napus): variation in transgenic and conventionally bred cultivars. J Agric Sci 142:29-40. doi:10.1017/ S0021859604003892

Guadagnuolo R, Savova-Bianchi D, Felber F (2001) Gene flow from wheat (Triticum aestivum L.) to jointed goatgrass (Aegilops cylindrica Host.), as revealed by RAPD and microsatellite markers. Theor Appl Genet 103:1-8. doi:10.1007/s001220100636

Hanke I, Wittmer I, Bischofberger S, Stamm C, Singer H (2010) Relevance of urban glyphosate use for surface water quality. Chemosphere 81:422-429. doi:10.1016/j.chemosphere.2010.06.067

Hanson BD, Mallory-Smith CA, Price WJ, Shafil B, Thill DC, Zemetra RS (2005) Interspecific hybridization: potential for movement of herbicide resistance from wheat to jointed goatgrass (Aegylops cylindrica). Weed Technol 19:647-682. doi:10.1614/WT-04-217R.1

Harwood JD, Wallin WG, Obrycki JJ (2005) Uptake of Bt endotoxins by nontarget herbivores and higher order arthropod predators: molecular evidence from a transgenic corn agroecosystem. Mol Ecol 14:2815-2823. doi:10.1111/j.1365-294X.2005.02611.x

Harwood JD, Samson RA, Obrycki JJ (2007) Temporal detection of cry1 Ab-endotoxins in coccinellid predators from fields of Bacillus thuringiensis corn. Bull Entomol Res 97:643-648. doi: $10.1017 / \mathrm{S} 000748530700524 \mathrm{X}$

Haughton AJ, Champion GT, Hawes C, Heard MS, Brooks DR, Bohan DA, Clark SJ, Dewar AM, Firbank LG, Osborne JL, Perry JN, Rotherry P, Roy DB, Scott RJ, Woiwod IP, Birchall C, Skellern MP, Walker JH, Baker P, Browne EL, Dewar AJG, Garner BH, Haylock LA, Horne SL, Mason NS, Sands RJN, Walker MJ (2003) Invertebrate responses to the management of genetically modified herbicide-tolerant and conventional spring crops. II Within-field epigeal and aerial arthropods. Philos Trans R Soc Lond B 358:1863-1877

Hayes TB, Case P, Chui S, Chung D, Haeffele C, Haston K, Lee M, Mai VP, Marjuca Y, Parker J, Tsui M (2006a) Pesticide mixtures, endocrine disruptors, and amphibian declines: are we underestimating the impact? Environ Heal Perspect 114:40-50

Hayes TB, Stuart A, Mendoza M, Collins A, Noriega N, Vonk A, Johnston G, Liu R, Kpodzo D (2006b) Characterization of atrazine-induced gonadal malformations in african clawfrogs (Xenopus laevis) and comparisons with effects of an androgen antagonist (cyproterone acetate) and exogenous estrogen (17ßestradiol): support for the demasculinization/feminization hypothesis. Environ Heal Perspect 114:134-141

Heard MS, Hawes C, Champion GT, Clark SJ, Firbank LG, Haughton AJ, Parish AM, Perry JN, Rothery P, Scott RJ, Skellern MP, Squire GR, Hill MO (2003) Weeds in fields with contrasting conventional and genetically modified herbicide-tolerant crops. I. Effects on abundance and diversity. Philos Trans R Soc Lond B 358:18191832

Hilbeck A, Baumgartner M, Fried PM, Bigler F (1998a) Effects of transgenic Bacillus thuringiensis corn-fed prey on mortality and development of immature Chrysoperla carnea (Neuroptera: Chrysopidae). Environ Entomol 27:480-487

Hilbeck A, Moar WJ, Pusztai-Carey M, Filippini A, Bigler F (1998b) Toxicity of Bacillus thuringiensis cry1Ab toxin to the predator Chrysoperla carnea (Neuroptera: Chrysopidae). Environ Entomol 27:1255-1263

Hilbeck A, Moar WJ, Pusztai-Carey M, Filippini A, Bigler F (1999) Prey-mediated effects of cry1 $\mathrm{Ab}$ toxin and protoxin and cry $2 \mathrm{~A}$ protoxin on the predator Chrysoperla carnea. Entomol Exp Appl 91:305-316

Hofmann F, Epp R, Kalchschmid A, Kruse L, Kuhn U, Maisch B, Müller E, Ober S, Radtke J, Schlechtriemen U, Schmidt G, Schröder W, von der Ohe W, Vögel R, Wedl N, Wosniok W (2008) GVO-Pollenmonitoring zum Bt-Maisanbau im Bereich des NSG/FFH-Schutzgebietes Ruhlsdorfer Bruch. Umweltwiss Schadstoff Forsch 20:275-289

Höhn H, Naef A, Holliger E, Widmer A, Gölles M, Linder C, Dubuis PH, Kehrli P, Wirth J (2010) Empfohlene Pflanzenschutzmittel für den Erwerbsobstbau 2010. Flugschrift 122. Schweizerische Zeitschrift für Obst- und Weinbau Nr. 2, 2010: 1-19

Holliger E (2009) Feuerbrand in der Schweiz: Befallsentwicklung und Massnahmen in den letzten 10 Jahren. Nachr Dtsch Pflanzenschutzd 60:239

Hommel B, Strassemayer J, Pallutt B (2006) Bewertung von herbizidresistenten Kulturpflanzen in Bezug auf das Reduktionsprogramm chemischer Pflanzenschutz-Auswertung eines 8-jährigen Dauerversuchs mit glufosinatresistentem Raps und Mais. Zeitschrift für Pflanzenkrankheiten und Pflanzenschutz Sonderheft XX, 13-20

Howe CM, Berrill M, Pauli BD, Helbing CC, Werry K, Veldhoen N (2004) Toxicity of glyphosate-based pesticides to four North American frog species. Environ Toxicol Chem 23:1928-1938. doi:10.1897/03-71

Huber DM (2007) What about glyphosate-induced manganese deficiency? Fluid J Fall 2007:20-22

Hüsken A, Ammann K, Messeguer J, Papa R, Robson P, Schiemann J, Squire GR, Stamp P, Sweet J, Wilhelm R (2007) A major European synthesis of data on pollen and seed mediated gene flow in maize in the SIGMEA project, unpublished. http://www.botani schergarten.ch/Geneflow/Huesken-Synthesis-2007.pdf

Hütter E, Bigler F, Fried PM (2000) Transgene schädlingsresistente Pflanzen in der Schweiz? Agrarforschung 7:148-153

Icoz I, Stotzky G (2008) Fate and effects of insect-resistant Bt crops in soil ecosystems. Soil Biol Biochem 40:559-586. doi:10.1016/ j.soilbio.2007.11.002

Icoz I, Saxena D, Andow DA, Zwahlen C, Stotzky G (2008) Microbial populations and enzyme activities in soil in situ under transgenic corn expressing cry proteins from Bacillus thuringiensis. J Environ Qual 37:647-662

James C (2010) Global status of commercialized biotech/GM crops: 2010. ISAAA brief no. 42. ISAAA, Ithaca

Johal GS, Huber DM (2009) Glyphosate effects on diseases of plants. Eur J Agron 31:144-152. doi:10.1016/j.eja.2009.04.004

Johnson WG, Davis VM, Kruger GR, Weller SC (2009) Influence of glyphosate-resistant cropping systems on weed species shifts and glyphosate-resistant weed populations. Eur J Agron 31:162-172. doi:10.1016/j.eja.2009.03.008

Jones JDG (2011) Why genetically modified crops? Phil Trans R Soc A 369:1807-1816. doi:10.1098/rsta.2010.0345

Kasamba E, Copeland J (2007) Economics of co-existence measures of GM and conventional crops: oilseed rape in Fife (Scotland). Working paper SIGMEA project 
Kleter GA, Harris C, Stephenson G, Unsworth J (2008) Comparison of herbicide regimes and the associated potential environmental effects of glyphosate-resistant crops versus what they replace in Europe. Pest Manag Sci 64:479-488. doi:10.1002/ps.1513

Kravchenko AN, Hao X, Robertson GP (2009) Seven years of continuously planted Bt corn did not affect mineralizable and total soil C and total N in surface soil. Plant Soil 318:269-274. doi:10.1007/ s11104-008-9836-5

KTBL (2008) Betriebsplanung Landwirtschaft 2008/09. Kuratorium für Technik und Bauwesen in der Landwirtschaft, Darmstadt

Landwirtschaftliches Zentrum SG (2006) Neupflanzung von Hochstammobstbäumen im Rahmen von Vernetzungsprojekten und Pflanzaktionen

Lang A, Otto M (2010) A synthesis of laboratory and field studies on the effects of transgenic Bacillus thuringiensis $(\mathrm{Bt})$ maize on nontarget Lepidoptera. Entomol Exp Appl 135:121-134

Lang A, Vojtech E (2006) The effects of pollen consumption of transgenic Bt maize on the common swallowtail, Papilio machaon L. (Lepidoptera, Papilionidae). Basic and Appl Ecol 7:296-306. doi:10.1016/j.baae.2005.10.003

LaReesa Wolfenbarger L, Naranjo SE, Lundgren JG, Bitzer RJ, Watrud LS (2008) Bt crop effects on functional guilds of non-target arthropods: a meta-analysis. PLoS One 3:e2118

Ledermann T, Schneider F (2008) Verbreitung der Direktsaat in der Schweiz. Agrarforschung 15:408-413

Leu C, Singer H, Stamm C, Müller SR, Schwarzenbach RP (2004) Simultaneous assessment of sources, processes, and factors influencing herbicide losses due to surface waters in a small agricultural catchment. Environ Sci Technol 38:3827-3834. doi:10.1021/es0499602

Leu C, Singer H, Müller SR, Schwarzenbach RP, Stamm C (2005) Comparison of atrazine losses in three small headwater catchments. J Environ Qual 34:1873-1882. doi:10.2134/jeq2005.0049

Liphadzi KB, Al-Khatib K, Bensch CN, Stahlmann PW, Dille J, Todd T, Rice CW, Horak MJ, Head G (2005) Soil microbial and nematode communities as affected by glyphosate and tillage practices in a glyphosate-resistant cropping system. Weed Sci 53:536-545. doi:10.1614/WS-04-129R1

Lutman PJW (2003) Co-existence of conventional, organic and GM crops - role of temporal and spatial behaviour of seeds. In: Boelt B (ed) Proceedings of the 1st European conference on the coexistence of genetically modified crops with conventional and organic crops. Danish Institute of Agricultural Sciences, Research Centre Flakkebjerg, Slagelse, pp 33-42

Mäder P, Fliessbach A, Dubois D, Gunst L, Fried P, Niggli U (2002) Soil fertility and biodiversity in organic farming. Science 296:1694-1697. doi:10.1126/science. 1071148

Mäder P, Fliessbach A, Dubois D, Gunst L, Jossi W, Widmer F, Oberson A, Frossard E, Oehl F, Wiemken A, Gattinger A, Niggli U (2006) The DOK experiment (Switzerland). In: Raupp J, Pekrun C, Oltmanns M, Köpke U (eds) Long-term field experiments in organic farming. ISOFAR Scientific Series No. 1. Dr. Köster, Berlin, pp 41-58

Mann S (2011) Koexistenz möglich, Nutzen noch fraglich. Newsletter NFP59 6:1-4

Mann RM, Hyne RV, Choung CB, Wilson SB (2009) Amphibians and agricultural chemicals: review of the risks in a complex environment. Environ Pollut 157:2903-2927. doi:10.1016/ j.envpol.2009.05.015

Marvier M, Van Acker RC (2005) Can crop transgenes be kept on a leash? Front Ecol Environ 3:99-106. doi:10.1890/1540-9295 (2005)003[0093:CCTBKO]2.0.CO;2

Marvier M, McCreedy C, Regetz J, Kareiva P (2007) A meta-analysis of effects of $\mathrm{Bt}$ cotton and maize on nontarget invertebrates. Science 316:1475-1476. doi:10.1126/science.1139208

Menrad K, Gabriel A, Gylling M, Larsen A, Voltolina P, Stolze M, Morgner M, Oehen B, Maciejczak M, Gryson N, Eeckhout M
(2009) Costs and benefits of co-existence and traceability between GM and non-GM supply chains. CoExtra Synthesis report WP3, Weihenstephan

Menzel G, Lünsmann I, Middelhoff U, Breckling B, Schmidt G, Tillmann J, Windhurst W, Schröder W, Filser J, Reuter H (2005) Gentechnisch veränderte Pflanzen und Schutzgebiete-Wirksamkeit von Abstandsregelungen. Bundesamt für Naturschutz, Bad Godesberg

Meyer A, Hanser E, Dierauer HU (2008) Deckungsbeiträge. Ausgabe 2008. AGRIDEA, Lindau

Mijangos I, Becerril JM, Albizu I, Epelde L, Garbisu C (2009) Effects of glyphosate on rhizosphere soil microbial communities under two different plant compositions by cultivation-dependent and -independent methodologies. Soil Biol Biochem 41:505-513. doi:10.1016/j.soilbio.2008.12.009

Møller HE, Djurhuus J (1997) Nitrate leaching as influenced by soil tillage and catch crop. Soil Tillage Res 41:203-219

Nowicki P, Weeger C, van Meijl H, Banse M, Helming J, Terluin I, Verhoog D, Overmars K, Westhoek H, Knierim A, Reutter M, Matzdorf B, Meargraf O, Mnatsakanian R (2007) Scenar 2020 Scenario study on agriculture and the rural world. European Commission, DG Agriculture and Rural Development. http://ec.euro pa.eu/agriculture/agrista/2006/scenar2020/final_report/ scenar2020final.pdf

Obrist LB, Dutton A, Albajes R, Bigler F (2006) Exposure of arthropod predators to cry $1 \mathrm{Ab}$ toxin in Bt maize fields. Ecol Entomol 31:143-154. doi:10.1111/j.0307-6946.2006.00762.x

Park JR, McFarlane I, Hartley Phillips R, Ceddia G (2011) The role of transgenic crops in sustainable development. Plant Biotechnol J 9:2-21

Paustian K (2005) Soils, global change and global sustainability. 15th meeting of the Italian Society of Ecology, Torino 2005

Peterson G, Cunningham S, Deutsch L, Erickson J, Quinlan A, RaezLuna E, Tinch R, Troell M, Woodbury P, Zens S (2000) The risks and benefits of genetically modified crops: a multidisciplinary perspective. Conserv Ecol 4:13

Peterson JA, Obrycki JJ, Harwood JD (2009) Quantification of Btendotoxin exposure pathways in carabid food webs across multiple transgenic events. Biocontrol Sci Tech 19:613-625. doi:10.1080/09583150902968972

Powles SB (2008) Evolved glyphosate-resistant weeds around the world: lessons to be learnt. Pest Manag Sci 64:360-365. doi: $10.1002 /$ ps. 1525

Reichenberger S, Bach M, Skitschak A, Frede HG (2007) Mitigation strategies to reduce pesticide inputs into ground- and surface water and their effectiveness; a review. Sci Total Environ 384:135. doi:10.1016/j.scitotenv.2007.04.046

Reim S (2008) Beiträge zur Bewertung der Umweltverträglichkeit gentechnisch veränderter Apfelgehölze. Dissertation. JuliusKühn-Institut, Bundesforschungsinstitut für Kulturpflanzen, Quedlinburg

Reim S (2009) Erhaltung von Malus sylvestris unter in situ-Bedingungen im Osterzgebirge. Nachwuchswissenschaftlerforum 2009. Julius-Kühn-Archiv 424:38-40

Reitmeier D, Menrad K, Demont M, Diems W, Turley D (2006) Methods for calculation of co-existence costs in agriculture. Task Guidelines of WP 5 within Project SIGMEA. http://www.wzstraubing.de/fachhochschule-weihenstephan/download/ wp $\% 205$ guidelines 5 .pdf

Relyea RA (2005) The lethal impact of Roundup on aquatic and terrestrial amphibians. Ecol Appl 15:1118-1124. doi:10.1890/04-1291

Relyea RA, Schoeppner NM, Hoverman JT (2005) Pesticides and amphibians: the importance of community context. Ecol Appl 15:1125-1134. doi:10.1890/04-0559

Rodrigo-Simon A, de Maagd RA, Avilla C, Bakker PL, Molthoff J, Gonzalez-Zamora JE, Ferré J (2006) Lack of detrimental effect of 
Bacillus thuringiensis cry toxins on the insect predator Chrysoperla carnea: a toxicological, histopathological and biochemical analysis. Appl Environ Microbiol 72:1595-1603. doi:10.1128/ AEM.72.2.1595-1603.2006

Romeis J, Dutton A, Bigler F (2004) Bacillus thuringiensis toxin $($ cry1 $\mathrm{Ab})$ has no direct effect on larvae of the green lacewing Chrysoperla carnea (Stephens) (Neuroptera: Chrysopidae). J Insect Physiol 50:175-183. doi:10.1016/j.jinsphys.2003.11.004

Rosi-Marshall EJ, Tank JL, Royer TV, Whiles MR, Evans-White M, Chambers C, Griffiths NA, Pokelsek J, Stephan ML (2007) Toxins in transgenic crop byproducts may affect headwater stream ecosystems. PNAS 104:16204-16208. doi:0.1073/pnas.0707177104

Roy DB, Bohan DA, Haughton AJ, Hill MO, Osborne JL, Clark SJ, Perry JN, Rotherry P, Scott RJ, Brooks DR, Champion GT, Hawes C, Heard MS, Firbank LG (2003) Invertebrates and vegetation of field margins adjacent to crops subject to contrasting herbicide regimes in the Farm Scale Evaluations of genetically modified herbicidetolerant crops. Philos Trans R Soc Lond B 358:1879-1898

Russell W (2008) GMOs and their contexts: a comparison of potential and actual performance of GM crops in a local agricultural setting. Geoforum 39:213-222

Sanvido O, Widmer F, Winzeler M, Streit B, Szerencsits E, Bigler F (2005) Koexistenz verschiedener landwirtschaftlicher Anbausystems mit und ohne Gentechnik. Schriftenreihe der FAL 55. Agroscope FAL Reckenholz, Zürich

Sanvido O, Stark M, Romeis J, Bigler F (2006) Ecological impacts of genetically modified crops. Experiences from ten years of experimental field research and commercial cultivation. Agroscope ART, Zürich

Schärer H-J (2000) Feuerbrand, ein Dauerbrenner. Agrarforschung 7:404-409

Schaub L, Auer J (2008) 50 Jahre Prävention der Zystennematoden der Kartoffel. Press release of 2.12.2008. Agroscope ACW

Schmidt JEU, Braun CU, Whitehouse LP, Hilbeck A (2009) Effects of activated $\mathrm{Bt}$ transgene products (cry $1 \mathrm{Ab}$, cry $3 \mathrm{Bb})$ on immature stages of the ladybird Adalia bipunctata in laboratory ecotoxicity tests. Arch Environ Contam Toxicol 56:221-228. doi:10.1007/ s00244-008-9191-9

Schoch H (2009) Preiskatalog. Ausgabe 2009. AGRIDEA, Lindau

SFZ (2011) Sortenangebot 2011. Leistungsprüfung 2008-2010. Schweizerische Fachstelle für Zuckerrübenanbau. www.zuckerruebe.ch

Singer HP, Anfang HG, Lück A, Peter A, Müller SR (2005) Pestizidbelastung der Oberflächengewässer. gwa - Gas Wasser Abwasser 11/2005, 879-886

Snow AA, Andow DA, Gepts P, Hallerman EM, Power A, Tiedie JM, Wolfenbarger LL (2005) Genetically engineered organisms and the environment: current status and recommendations. Ecol Appl 15:377-404

Solomon KR, Carr JA, Du Preez LH, Giesy JP, Kendall RJ, Smith EE, Van der Kraak GJ (2008) Effects of atrazine on fish, amphibians, and aquatic reptiles: a critical review. Crit Rev Toxicol 38:721772. doi:10.1080/10408440802116496

Soukup J, Holec J, Jursik M, Hamouzova K (2011) Environmental and agronomic monitoring of adverse effects due to cultivation of genetically modified herbicide tolerant crops. J Verbr Lebensm 6:S125-S130. doi:10.1007/s00003-011-0682-7

Steinbach HS, Alvarez R (2006) Changes in soil organic carbon contents and nitrous oxide emissions after introduction on no-till in Pampean agroecosystems. J Environ Qual 35:3-13. doi:10.2134/ jeq2005.0050

Stotzky G (2004) Persistence and biological activity in soil of the insecticidal proteins from Bacillus thuringiensis, especially from transgenic plants. Plant Soil 266:77-89. doi:10.1007/s11104-005-5945-6
Strandberg B, Pedersen MB (2002) Biodiversity in glyphosate tolerant fodder beet fields - timing of herbicide application. NERI Technical Report No. 410. National Environmental Research Institute, Denmark. Available at: http://www2.dmu.dk/1_viden/2_Publika tioner/3 fagrapporter/rapporter/FR410.pdf

Sweet J, Simpson E, Law J, Lutman P, Berry K, Payne R, Champion G, May M, Walker K, Wightman P, Lainsbury M (2004) Botanical and rotational implications of genetically modified herbicide tolerance in winter oilseed rape and sugar beet (BRIGHT Project). HGCA Project Report No. 353. Home Grown Cereals Authority, London. Available at: www.hgca.com

Swiss Federal Council (2002) Sustainable Development Strategy 2002

Tank JL, Rosi-Marshall EJ, Royer TV, Whiles MR, Griffits NA, Frauendorf TC, Treering DJ (2010) Occurrence of maize detritus and a transgenic insecticidal protein $(\operatorname{cry} 1 \mathrm{Ab})$ within the stream network of an agricultural landscape. Proc Natl Acad Sci. doi:10.1073/pnas. 1006925107

Tappeser B, Eckelkamp C, Weber B (2000) Untersuchungen zu tatsächlich beobachteten nachteiligen Effekten von Freisetzungen gentechnisch veränderter Organismen. Monographien Band 129. Umweltbundesamt, Wien

Trigo EJ, Cap EJ (2006) Ten years of genetically modified crops in argentine agriculture. ArgenBio. pp. 1-52

UNDSD. (1992) Agenda 21. Konferenz der Vereinten Nationen für Umwelt und Entwicklung, Rio de Janeiro

United Nations General Assembly. (1987) Our common future, from one earth to one world. Report of the World Commission on Environment and Development. A/42/427

Vogler U, Rott AS, Gessler C, Dorn S (2010) How transgenic and classically bred apple genotypes affect non-target organisms on higher trophic levels. Entomol Exp Appl 134:114-121. doi:10.1111/j.1570-7458.2009.00942.x

Watkinson AR, Freckleton RP, Robinson RA, Sutherland WJ (2000) Predictions of biodiversity response to genetically modified herbicide-tolerant crops. Science 289:1554-1557. doi:10.1126/ science.289.5484.1554

Weaver MA, Krutz LJ, Zablotowicz RM, Reddy KN (2007) Effects of glyphosate on soil microbial communities and its mineralisation in a Mississippi soil. Pest Manag Sci 63:388-393

Weibel FP, Leder A (2007) Experiences with the Swiss (organic) method how to introduce new apple varieties into retail market: Flavour Group Concept and Variety Team. Compact Fruit Tree 40:1-5

Wolf D (2009) Erfahrungen zum ökonomischen Nutzen herbizidtoleranter Kulturen. Agrarforschung 16:52-57

Wolf D, Albisser Vögeli G (2009) Ökonomischer Nutzen von Bt-Mais ist relativ. Agrarforschung 16:4-9

Wyss E (1995) The effects of weed strips on aphids and aphidophagous predators in an apple orchard. Entomol Exp Appl 75:43-49. doi:10.1111/j.1570-7458.1995.tb01908.x

Yamada T, Kremer RJ, de Camargo e Castro PR, Wood BW (2009) Glyphosate interactions with physiology, nutrition, and diseases of plants: threat to agricultural sustainability? Eur J Agron 31:111-113. doi:10.1016/j.eja.2009.07.004

Zeller SL, Kalinina O, Brunner S, Keller B, Schmid B (2010) Transgene $\mathrm{x}$ environment interactions in genetically modified wheat. PLoS One 5:e11405. doi:10.1371/journal.pone.0011405

Zhao JH, Ho P, Azadi H (2011) Benefits of Bt cotton counterbalanced by secondary pests? Perceptions of ecological change in China. Environ Monit Assess 173:985-994. doi:10.1007/s10661-010$1439-y$

Zwahlen C, Andow DA (2005) Field evidence for the exposure of ground beetles to cry $1 \mathrm{Ab}$ from transgenic corn. Environ Biosaf Res 4:113-117. doi:10.1051/ebr:2005014 